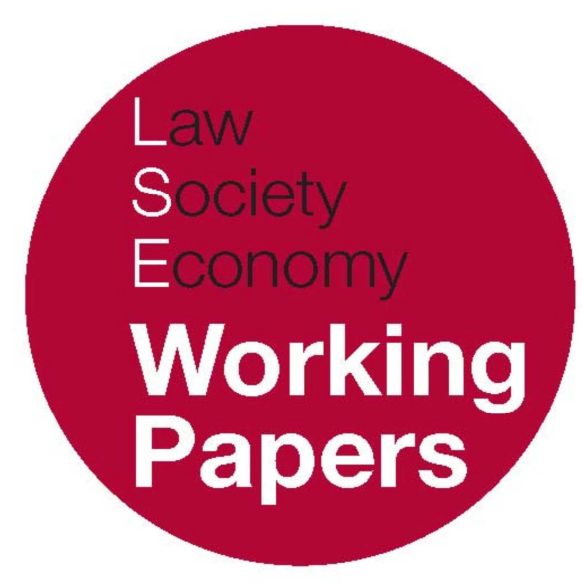

\title{
Determinants of Corporate Governance Codes
}

Carsten Gerner-Beuerle

LSE Law, Society and Economy Working Papers 5/2014 London School of Economics and Political Science

Law Department

This paper can be downloaded without charge from LSE Law, Society and Economy Working Papers at: www.lse.ac.uk/collections/law/wps/wps.htm and the Social Sciences Research Network electronic library at: http://ssrn.com/abstract $=2346673$.

(C) Carsten Gerner-Beuerle. Users may download and/or print one copy to facilitate their private study or for non-commercial research. Users may not engage in further distribution of this material or use it for any profit-making activities or any other form of commercial gain. 


\title{
Determinants of Corporate Governance Codes
}

\author{
Carsten Gerner-Beuerle *
}

\begin{abstract}
Corporate governance codes are an increasingly prominent feature of the regulatory landscape in many countries, yet remarkably little is known about the determinants of corporate governance reform. Potential determinants include: (1) the diffusion of an international benchmark model of good governance; (2) a country's legal system; (3) the desire to attract foreign investors; and (4) the influence of interest groups. I construct a proxy for the investor-friendliness of 52 corporate governance codes of different jurisdictions and collect data on the code issuers. I find strong evidence that the drafters of codes emulate international benchmark models and that jurisdictions belonging to different legal traditions use different regulatory strategies, some evidence that portfolio equity inflows are associated with the investor-friendliness of codes, and no evidence that interest groups succeed in affecting rules. The article suggests a method for the modeling of legal evolution, convergence, and the political economy of corporate governance codes.
\end{abstract}

Keywords: Corporate governance codes; board structure; empirical legal research; interest group politics; convergence.

\footnotetext{
* Law Department, London School of Economics and Political Science. I am grateful to Michael Blackwell, Tom Kirchmaier, Edmund-Philipp Schuster, Mathias Siems, Hanne Søndergaard Birkmose, Moqi Xu, and the participants of workshops at the LSE, the Department of Financial \& Management Studies, SOAS, University of London, and the University of St. Gallen for valuable comments. Special thanks are due to Michael Schouten for the idea to code corporate governance committees at the member-level and for collaboration in collecting the data. All mistakes are mine.
} 


\section{INTRODUCTION}

Corporate governance codes play an increasingly important role as a regulatory tool and part of a country's corporate governance system. In many jurisdictions, listed companies are now required to publish a statement as part of their annual report indicating whether they comply with the corporate governance code in force in their jurisdiction and provide an explanation if they deviate from the code's requirements. ${ }^{1}$ The effectiveness of this so-called 'comply or explain' principle, and generally of regulating by means of soft law, has been discussed extensively in the law and finance literature (see, for example, Andres and Theissen 2008; Arcot, Bruno, and Faure-Grimaud 2010; MacNeil and Li 2006). However, remarkably little is known about the drivers of corporate governance reform and the factors that determine the content of the codes. This is problematic, given that the regulatory goal of corporate governance codes to strengthen the accountability of managers depends not only on the compliance by companies with the code provisions, but also on the form and content of these provisions. Explanatory factors may or may not be conducive to the goal of investor protection, and understanding their influence on the drafting process is important in assessing how corporate governance codes evolve and whether they achieve their regulatory goal.

This study examines the determinants of corporate governance reform and whether the affiliation of those who draft corporate governance codes with the investor or issuer community influences the content of the rules that they promulgate. I first collect data on the identity of the issuers of 52 corporate governance codes in 23 European countries covering 98.3 percent of the market capitalization of the EEA including Switzerland, ${ }^{2}$ as well as the members of the committees that drafted the codes and their affiliations. ${ }^{3}$ The data shows that there is significant variation across countries. In many countries, for example Belgium, Denmark, France, and Switzerland, codes are drafted by committees that consist overwhelmingly of issuer representatives, whereas in other countries, such as Norway and, recently, the United Kingdom, the investor community is more strongly represented. A third group of countries, including Poland, Portugal, and Spain, has set up corporate governance committees largely composed of technocrats. Second, I measure the development of the issuer countries' capital markets and their attractiveness to foreign investors by using data from the World Bank's World Development Indicators on market capitalization, foreign direct

\footnotetext{
1 This requirement applies to all Member States of the EU, see Directive 2006/46/EC of the European Parliament and of the Council of 14 June 2006, OJ L 224 of 16.08.2006, p. 1, Art. 1(7) (now Directive 2013/34/EU of the European Parliament and of the Council of 26 June 2013 on the annual financial statements, consolidated financial statements and related reports of certain types of undertakings, OJ L 182 of 29.06 .2013 , p. 19 , Art. 20).

2 Based on data from 2011. Source: World Bank World Development Indicators.

3 The sample does not cover all Member States of the EU because data on the individuals who sit on corporate governance committees are not always available.
} 
investment, and portfolio equity inflows. Third, I develop several indicators of the legal and political environment in the issuer country. In line with previous research (La Porta, Lopez-de-Silanes, Shleifer, and Vishny 1999, 2000), the countries in the sample are divided by legal tradition into common law as well as French, German, and Scandinavian-origin countries. ${ }^{4}$ Additional controls capture differences in statutory rules on board structure ${ }^{5}$ and the effectiveness of the political process. Finally, I assume that drafters take into account evolving international standards of good governance and the spread of corporate governance mechanisms developed in one country ('benchmark' codes of good governance) to other jurisdictions. This diffusion of regulatory mechanisms is modeled by including a time trend and quantifying the rules contained in the benchmark codes.

I then assess the level of investor-friendliness of the codes in the sample. In order to do so, I develop a matrix that captures a central regulatory strategy of every corporate governance system: the composition of corporate boards, notably the requirement to have a specified number of independent non-executive directors on the board, separation of the roles of chairman and CEO, imposition of a cooling-off period before the CEO can go on to become chairman of the board, and the delegation of decisions that involve particularly sensitive issues to board committees. I analyze the relevant provisions of each code and quantify them according to whether they adopt solutions that tend to protect investors by establishing structures that control management effectively (for example, by requiring a high proportion of independent directors on the board or entrusting committees with the mitigation of conflicts of interests), or leave considerable discretion to the managers. In this way, I obtain an indicator of the investorfriendliness' of the codes.

The data enable me to test the following hypotheses. (1) If interest groups have a significant influence on the drafting process, we would expect committees dominated by issuer representatives to draft codes that provide for less stringent control structures than committees dominated by investor representatives. (2) If codes with strong investor protection mechanisms coincide with the presence of institutional investors, in particular international investors accustomed to strict Anglo-American standards of management accountability, we would expect the investor-friendliness of codes to be associated with the size of a country's capital markets and inflows of foreign investment. The direction of the relationship, however, is somewhat ambivalent. It is plausible to argue that a high level of investor-friendliness is positively associated with market capitalization and capital inflows because foreign investors exert pressure on domestic policy-makers to improve their corporate governance regimes. On the other hand, weak capital markets and low capital inflows may prompt policy-makers to amend corporate governance rules proactively in order to attract foreign direct investment. In this

\footnotetext{
${ }^{4}$ The appropriateness of this distinction, and deviations from prior research, will be discussed in Section 3 below.

5 This study focusses on the distinction between one-tier and two-tier board models and rules requiring employee representatives on corporate boards.
} 
case we would expect to see a negative relationship. This ambivalence exemplifies a larger problem when the impact of legal rules on economic outcomes is examined. Realistically, the relationship is not unidirectional, but best described as one of mutual influence of legal, economic, and political factors (Coffee 2001). (3) Corporate governance codes are part of the wider regulatory landscape in the issuer countries. It is reasonable to assume that this regulatory landscape influences regulatory styles and techniques and that we can, therefore, identify differences between legal traditions. In particular, if it is correct, as claimed by parts of the literature (La Porta, Lopez-de-Silanes, Shleifer, and Vishny 1999, 2000; La Porta, Lopez-de-Silanes, and Shleifer 2008), that jurisdictions in the common law tradition have a predisposition to stronger investor protection than those in the civil law tradition, we would expect this to be reflected in the codes. ${ }^{6}$ (4) If drafters are informed by, and receptive to, internationally accepted notions of what constitutes good governance, which are, for example, transmitted by codes regarded as benchmark models or by international or supranational initiatives, the content of the codes should change as such benchmark codes and initiatives spread and develop.

I model the influence of these factors as a linear relationship, with the proxy for the investor-friendliness of corporate governance codes as dependent variable and the composition of the committees drafting corporate governance codes, indicators of the development of the capital markets, legal families and board model dummies, and the diffusion of benchmark codes as explanatory variables. I find that the diffusion of benchmark codes of good governance is positively correlated with the investor-friendliness of codes adopted in other countries. The correlation is statistically significant at the 1 percent level and of large magnitude. For example, if we regard the UK codes as a benchmark and ask what influence the level of investor-friendliness of the UK code has on the content of other codes adopted later, we find that a one-unit increase in the level of investorfriendliness of the UK code translates into a 0.55-unit increase in the level of investor-friendliness of subsequent codes adopted by other countries. ${ }^{7}$ Expressed in standardized coefficients, a one standard-deviation increase in the investorfriendliness of the UK code is associated with a 0.53-standard-deviation increase in subsequent codes. One interpretation could be that other countries react to regulatory innovations stemming from a country that is commonly regarded as a pioneer in the corporate governance movement. However, the reception of regulatory innovations is muted and not a one-to-one relationship. Countries adopt part of the foreign innovations, but they are also informed by their own

\footnotetext{
${ }^{6}$ La Porta et al.'s claim is, of course, very controversial, see, e.g., Cools (2005), and it is important to take account of the opposing view in the interpretation of the results of this study. For a more detailed discussion see Section 3 below.

${ }^{7}$ In order to measure the effect of the benchmark code on corporate governance codes adopted by other countries, I use the UK code in force in the year before adoption of the response code. Therefore, the explanatory variable measures the level of investor-friendliness of the UK codes over time.
} 
regulatory environment and legal traditions. If we model the dissemination of innovations in corporate governance as the time lag between the first comprehensive initiative in Europe, the UK Cadbury Report of 1992, and the adoption of the response code, we find that the level of investor-friendliness of codes tends to increase by 0.03 per year in absolute terms, where investorfriendliness is measured on a scale from 0 to 1 , or by 9.7 percent each year.

The results also show that German and French legal origins are negatively correlated with the level of investor-friendliness. The results are statistically significant at the 1 or 5 percent level under most model specifications. The lower scores in the legal variables, and accordingly the negative coefficients, are often a function of a more open-ended and less prescriptive way of regulating the conflicts that corporate governance codes are intended to address. However, it is important not to draw conclusions regarding the general level of investor protection offered by these countries. I do not assess the general legal framework of the countries and do not attempt to account for substitutes for weak corporate governance mechanisms in a jurisdiction's binding laws. ${ }^{8}$

I furthermore find some evidence that the presence of foreign investors in a country, illustrated by high portfolio equity inflows, is positively correlated with a higher level of investor-friendliness, indicating that corporate governance committees are sensitive to the expectations of foreign investors. I do not, however, find consistent evidence that interest groups succeed in influencing the writing of codes in a significant way. I cannot reject the hypothesis that the coefficient on the variable measuring the committee members' affiliation (as issuer or investor representatives) is zero under all except one model specification, which is, however, not the preferred specification as far as the model's fit and underlying theory are concerned. ${ }^{9}$ These findings indicate that interest group politics are less important for the design of corporate governance mechanisms than anecdotal evidence reported in the literature (Schouten 2009) suggests. Policy-makers generally seem to be motivated by the desire to meet and incorporate internationally accepted standards of good governance, rather than to serve the interests of an affiliated group.

I perform several robustness checks. Most importantly, I develop two alternative methods of computing the investor/issuer-orientation of corporate governance committees and introduce a simplified, binary coding of the legal variables in order to safeguard against potentially subjective interpretations of the code provisions. The results remain unchanged; in particular, benchmark codes and the diffusion of corporate governance initiatives measured as the time lag since the Cadbury Report continue to be positively correlated with outcomes and statistically significant at the 1 percent level. German legal origin continues to be

\footnotetext{
${ }^{8}$ See Cools (2005) for a discussion of potential substitutes.

${ }^{9}$ Economic magnitude of the author variable, calculated as the coefficient times standard deviation, is very small, between 0.04 and 0.00024 depending on the model specification (where both dependent and independent variable are continuous and measured on a scale from 0 to 1 ), and the standard error large (p-values are between 0.6 and 0.9 for the model with the best fit).
} 
negatively correlated and statistically significant. The committees' investor/issuerorientation is insignificant under all specifications.

The remainder of the paper is organized as follows. Section 2 reviews the related literature; Section 3 discusses methodological challenges that arise when legal rules are coded to render them suitable for quantitative analysis; Sections 4 and 5 describe the data and construction of the legal index measuring the level of investor protection achieved by corporate governance codes; Section 6 presents and interprets the results; Section 7 analyzes whether the data confirms the claim often advanced in the literature that corporate governance systems converge; ${ }^{10}$ and Section 8 concludes. The appendices contain a detailed description of the legal variables and the coding protocol.

\section{LITERATURE}

This study is related to two strands of the corporate governance literature, (1) the literature on corporate governance codes, and (2) the literature on interest group politics.

Research on the issuers of codes has so far been limited in scope, focusing on whether codes are issued by, for example, governments or stock exchanges. A recent study observes that initially, in the late 1990s and early 2000s, when corporate governance codes were issued for the first time in most European countries, governments played a crucial role (RiskMetrics 2009). Over time, private institutions, notably stock exchanges, have assumed the initiative. However, the identity of the code issuer is likely to be of limited relevance. This is because in practice we often see that the issuer of the code sets up a committee in charge of the actual drafting of the code. Such committees typically consist of issuer representatives, investor representatives, and third parties such as law professors and accountants. To obtain a better understanding of who actually writes corporate governance codes, we need to look at code issuers at a more granular level.

Three studies have examined the identity of code issuers. An early report prepared by Weil, Gotshal, and Manges (2002) identifies the issuers of corporate governance codes published in the EU Member States between 1991 and 2001. The report distinguishes between several categories, including governmental entities, committees organized by governments, stock-exchange relates bodies, business associations, and investor groups. The study finds that almost one-third of the number of codes has been issued by institutional investor associations. Aguilera and Cuervo-Cazurra (2004) collect data on the issuers of codes

10 The claim by Hansmann and Kraakman (2000) that we witness "the end of history for corporate law" has become very famous. 
worldwide and distinguish between similar categories. They find that issuer types have shifted over time, and observe that the claim that institutional investors were the primary triggers of good governance is not supported by their data, which indicates that managers' and directors' associations have played an active role. Finally, the 2009 study by RiskMetrics mentioned earlier looks at the origin of the initial corporate governance code initiatives. This study distinguishes between public initiatives, public/private initiatives and private initiatives (comprising stock exchanges and representative organizations), and finds that most codes, particularly recent codes, stem from private initiatives.

Aguilera and Cuervo-Cazurra (2009) review the literature on corporate governance codes and observe that to date it has not been studied systematically how the nature of the code issuer affects the content of codes. Such an examination is also warranted in light of a call by Bebchuk and Weisbach (2010) to study how corporate governance arrangements are influenced by interest group politics. Their call is motivated by a theoretical study by Bebchuk and Neeman (2010) who have modeled the competition among interest groups for influence over policymakers setting the level of investor protection. In their model, a low level of investor protection enables firm insiders to extract rents (in the form of private benefits of control), which gives them a powerful incentive to lobby against legal reforms enhancing investor protection. Several empirical studies have examined the role of interest groups in corporate law making further. Roe (2005) has shown that the political economy is a major factor in US corporate law making; Armour and Skeel (2006) have shown that the divergence between US and UK takeover regulation can be explained in terms of what they refer to as the 'mode' of regulation, i.e. by taking into account who writes the rules for hostile takeovers. Schouten (2010) has analyzed the legislative process surrounding recent European legislation aimed at facilitating cross-border voting and found that financial intermediaries have had a particularly strong voice throughout the legislative process, which may in part explain the outcome of this process. Similarly, Ferran (2011) has documented the influence of interest groups on the legislative process leading to the EU Alternative Investment Fund Managers Directive.

\section{METHODOLOGY}

Although the quantitative analysis of legal rules is not a novel development in law and finance scholarship, the best research design to ensure reliable results continues to be controversial. The pioneering work of La Porta, Lopez-de-Silanes, Shleifer, and Vishny (LLSV), who constructed legal indices by assigning the value of 1 if a particular legal mechanism was present in a country's legal system and 0 if it was absent (see, for example, LLSV 1997, 1998, for their anti-director and creditor rights indices or La Porta, Lopez-de-Silanes, and Shleifer 2006, for several 
securities law indices), was heavily criticized for mistakes in the definition and coding of the legal variables that they developed (for only a few contributions from the voluminous literature, see Armour, Deakin, Mollica, and Siems 2010, Armour, Deakin, Sarkar, Siems, and Singh 2009, Armour, Deakin, Lele, and Siems 2009, Cheffins 2001, Coffee 2001, Siems 2005a, Spamann 2006, 2009c). More specifically, it was argued that the definitions did not take account of the existence of functional substitutes, interactions between norms, and difficulties in the comparison of norms that were structured and conceptualized against the background of different jurisdictions and legal traditions. The critics also claimed that the binary coding failed to appreciate nuances in the operation of the legal rules and that some rules simply had been misunderstood or coded inconsistently between countries. Furthermore, the classification of the analyzed jurisdictions into four legal families, common law as well as the French, German, and Scandinavian legal families, was criticized as not being in line with modern comparative legal scholarship. LLSV answered their critics in a paper that summarized their prior research and reinforced their conclusions (La Porta, Lopez-de-Silanes, and Shleifer 2008). The controversy, therefore, remains somewhat unresolved.

Since this study is in the tradition of LLSV in that it quantifies legal rules in order to render them amenable to statistical analysis, it needs to address the methodological challenges raised in the 'legal origins' debate. However, I will not engage in a comprehensive, critical review of the arguments advanced in this context. A considerable number of scholarly contributions have been devoted to this question. ${ }^{11}$ In the following paragraphs, I merely set out how the challenges affect this study. Where necessary, I propose modifications in order to develop the methodology further and make allowance for the problems identified in the literature.

It is helpful to distinguish between three main methodological problems in quantitative legal research assessing two or more jurisdictions: ${ }^{12}$ (1) the functional character of comparative law; (2) the complexity of legal rules, which is a consequence both of their often ambivalent nature, giving rise to interpretive

11 It should be noted, though, that the ideal methodology for empirical legal research is far from settled and universally accepted. When Zweigert and Kötz observed 15 years ago that comparative legal methodology was 'still at the experimental stage' (Zweigert and Kötz 1998, p. 33), then this assessment must apply even more so to the fledgling discipline of quantitative (comparative) legal research, and more work is required to erect a sound methodological foundation for this type of research (for a step in this direction see Spamann 2009b).

12 One additional issue, LLSV's claim that legal origins have an effect on various economic outcomes, for example the development of a country's capital markets, in the sense of economic causality, seems to be of less importance for present purposes. This claim was challenged because legal origins cannot necessarily be assumed to be exogenous. Rather, it is plausible to argue that the relationship between law and the economic environment is characterized by interdependence and mutual feedbacks, a relationship that has been described as 'coevolution' (Armour, Deakin, Mollica, and Siems 2010, pp. 1448-1453). The present study, on the other hand, does not make any causal claims regarding the evolution of legal and economic systems, but examines whether and how the chronologically fixed event of the adoption of a code of good governance was influenced by pre-existing economic, political, and legal conditions. 
questions, and the multi-layered technique of drafting, where a legal outcome depends on a number of preconditions and exceptions as well as the interaction between rules from the same or different legal areas; and (3) the difficulty to derive general conclusions that go beyond the particularities of an individual legal system and hold for groups of countries, for example, legal families. I will discuss the three problems in turn.

It is well established that the comparative analysis of legal rules cannot take legal concepts or regulatory solutions from one jurisdiction as its starting point. ${ }^{13}$ Since legal systems may address the same social conflict, and achieve similar results in solving the conflict, with different legal techniques, comparative analysis must start from the social problem under investigation and search for functionally comparable rules, i.e. those rules that are designed to address the same social conflict, notwithstanding their provenance in the legal systems or the regulatory strategy employed (Michaels 2006; Zweigert and Kötz 1998, pp. 33-36). However, a purely non-legal formulation of the social problem is unrealistic. In practice, the majority of comparative researchers go back and forth between the investigated social phenomenon and possible legal responses in order to define and delimit the research question (Tschentscher 200714). For our purposes, a certain legally qualified understanding of corporate governance and approaches to regulating corporate boards is necessary to develop legal variables suitable to quantify the content of corporate governance codes. But the task at hand is, arguably, less problematic than that of the comparative researcher who wishes to assess a company's legal system. This study does not intend to measure the actual level of investor protection in a given jurisdiction, but the comparative strength of the signal that a corporate governance code sends to the investment community by providing for specified legal mechanisms. To this end, the study deals with a fairly small number of provisions laid down in the code, rather than the whole corpus of rules that constitute a country's legal system and that can potentially be utilized to protect investors. Thus, the risk of overlooking functional substitutes classified or conceptualized differently from one jurisdiction to another does not apply to the issue at hand. ${ }^{15}$ Furthermore, the arsenal of legal strategies used in corporate governance codes is limited and can be mapped onto well-established principles of what constitutes good governance stemming from international initiatives and

\footnotetext{
${ }^{13}$ This problem has also been referred to as 'home country bias': Researchers tend to phrase the research question in terms of the legal system most familiar to them (see Siems, 2007, p. 79 n. 98; Armour, Deakin, Lele, and Siems 2009, p. 586; Armour, Deakin, Sarkar, Siems, and Singh 2009, pp. 349, 355-357). ${ }^{14}$ See also Michaels 2006, pp. 368-369, arguing that the identification of the relevant social phenomenon is a 'constructive move'. Comparatists work in a 'hermeneutic circle'; they analyse legal institutions that potentially qualify as functional equivalents and, in doing so, 'construct the underlying problem and thereby $[\ldots]$ recognize the functions of a legal institution'.

15 However, a problem is the potential overlap between a country's corporate governance code and its binding laws. The fact that a particular provision is not contained in the code may either indicate a regulatory gap or that the country's binding company law deals with the matter. I discuss this issue below in Section 4.
} 
scholarly contributions. ${ }^{16}$ I describe in detail below how I frame the social conflict underlying the legal variables and draw on international corporate governance initiatives in defining the variables.

The second issue, the complexity and often open-ended or ambiguous formulation of legal rules, poses greater problems and is of central importance for all quantitative legal research. It has prompted some commentators to question the usefulness of quantitative legal research altogether (Siems 2005b) and others to emphasize the risks associated with a reductionist approach to comparative law that condenses legal rules into numbers (Michaels 2009). Inevitably, the quantification of social phenomena that are open to interpretation and rational disagreement as to their meaning involves a tradeoff between accuracy on the one hand and transparency and objectivity on the other hand (Gompers, Ishii, and Metrick 2003). A binary coding of legal rules must fail to capture the nuances that will often be decisive in real-life legal proceedings. It is, therefore, prone to measurement errors and will in any case lead to a loss of information. A more gradual quantification, on the other hand, necessarily requires value judgments that are only partly susceptible to objective verification.

I propose a dual approach to coding in order to capture both the nuances and gradual differences in the code provisions and provide for a mechanism that restricts the coder's discretion and allows for an easy replication of the coding exercise. The first approach, nuanced coding, is based on a detailed matrix containing six elements that determine the composition of corporate boards and the constraints within which executive directors are required to act. ${ }^{17}$ The coding is generally not binary, but includes intermediate scores that reflect the relative importance of incremental differences. The legal variables are, therefore, metric and the interval between two scores has a quantitative interpretation. The nuanced approach comprises, furthermore, a two-step analysis of the code provisions. In the first step, the provisions are assigned to the relevant grade of the legal matrix. Since no matrix, however detailed, is able to measure all variations that have an impact on the operation and effectiveness of the legal rule, I apply, in a second step, a qualitative adjustment if the quantification performed in the first step does not accurately reflect the true import of the rule. Several measures are taken to ensure transparency and consistency in the coding. First, detailed explanations for coding decisions and each adjustment that deviates from a mechanical application of the legal matrix are given in the coding protocol. ${ }^{18}$ Second, consistency is achieved by entrusting one person with the coding of all jurisdictions, rather than

\footnotetext{
${ }^{16}$ Influential international initiatives include the OECD Principles of Corporate Governance, first issued in 1999, and in the EU Commission Recommendation 2005/162/EC of 15 February 2005 on the role of non-executive or supervisory directors of listed companies and on the committees of the (supervisory) board, OJ L 52 of 25.02 .2005 , p. 51. For scholarly contributions see, for example, Monks and Minow (2011).

${ }^{17}$ The matrix is reproduced in full in Appendix A.

18 The coding protocol is contained in Appendix B.
} 
a multitude of country experts injecting idiosyncratic value judgments into the data gathering process. ${ }^{19}$ This is possible because this study is confined to the assessment of corporate governance codes, which are available in translation and contain, as mentioned, a limited number of regulatory tools that are well understood internationally and generally not dependent on functional complements from other areas of the legal system. In this sense, corporate governance codes are an ideal 'case study' for the political economy of rule-making because they are relatively insulated from the rest of the legal system and are also not a product of the whole institutional architecture devoted to legislating and enforcing law, but of a small group of known stakeholders and experts. In addition, detailed information about the corporate governance systems of the countries in the sample is nowadays easily accessible and allows for thorough comparative legal research. ${ }^{20}$ Where ambiguities remained, I consulted local lawyers for clarification and asked them to verify the coding.

Nevertheless, it is clear that a nuanced grading, in particular if performed by one researcher, may give rise to bias due to the subjective quality that is part of legal interpretation. For this reason, I also employ a simplified, mechanistic approach to coding. The mechanistic method largely excludes discretion by using a simple binary matrix, assigning 1 if the regulatory strategy is used in the code and 0 if it is not. No further adjustments are made. ${ }^{21}$ The simplified approach functions as a control mechanism. If the coefficients on the dependent variables do not switch signs and are, on the whole, similar to those under the nuanced approach, the nuanced coding can be taken not to add bias, and if the fit of the nuanced model is better than the binary model, the nuanced approach adds information and precision.

The third issue, the identification of common characteristics of two or more jurisdictions in order to derive general conclusions for particular regulatory styles, relates to the well-known 'legal origins' debate. LLSV concluded that common law was superior compared to civil law jurisdictions with respect to various economic outcomes based on their distinction between four major legal families: common law, French, German, and Scandinavian-origin jurisdictions (La Porta, Lopez-deSilanes, and Shleifer 2008). However, critics argued that LLSV overstated the differences between legal families, neglected the hybrid nature of many jurisdictions and did not consider that legal systems had converged significantly over the last decades (Armour, Deakin, Mollica, and Siems 2010). Notwithstanding these important points, for purposes of this article it is appropriate to distinguish between the four legal traditions and use legal origins as an explanatory variable. The reasons are as follows. It is correct that many (or most $^{22}$ ) jurisdictions are influenced by more than one legal tradition. Some have

\footnotetext{
${ }^{19}$ In large samples, the idiosyncratic deviations from an ideal (objective) interpretation may be said to cancel out if they are random, but this is not necessarily the case in samples of the size used here.

${ }^{20}$ See, for example, Gerner-Beuerle, Paech, and Schuster 2013.

${ }^{21}$ See Appendix B, Table B.7, for a description of the simplified matrix and the coding protocol.

22 See Michaels 2009, pp. 780-781.
} 
always been mixed systems. Increased international trade and the initiatives of international institutions transmit legal ideas or give impetus to legal reform. Furthermore, in the EU, the laws of the Member States are, of course, partly harmonized. However, if we do not attempt to classify legal systems as a whole, but analyze individual areas, it is often possible to recognize distinct regulatory strategies and interdependencies between jurisdictions. This is certainly true for the field of corporate governance and, more specifically, board structure regulation, at least if we restrict the comparative analysis to Europe. ${ }^{23}$ Comparative studies have shown that the four legal traditions can be distinguished quite clearly in their approaches to many issues of corporate governance (Gerner-Beuerle and Schuster 2013). In addition, in this article, legal origins are not linked with a general regulatory ideology. More narrowly, I argue that legal traditions may differ in the regulatory techniques that they employ, thus engendering differences in the content of corporate governance codes. The differences may be of a stylistic nature, reflect a different binding corporate law background or express genuine differences in the level of investor protection. Either way, including legal origins as an explanatory variable is useful.

The allocation of jurisdictions to legal traditions, however, differs from that of LLSV. In particular, I consider Greece and Portugal to belong to the German tradition, whereas LLSV classify these countries as French-origin. ${ }^{24}$ Both countries are mixed systems, influenced mainly by the French and German traditions. In Portugal, legal reforms of the $20^{\text {th }}$ century have shifted the focus from France to Germany (Zweigert and Kötz 1998, pp. 108-109). In corporate law and more specifically board structure regulation, strategies stemming from German law now feature more prominently, and especially the regulation of listed companies is informed predominantly by German corporate law. ${ }^{25}$ Greece has always been closer to the German tradition (Zweigert and Kötz 1998, pp. 155-156). This also holds for corporate law, even though influences from other legal traditions can be noticed, for example the one-tier board structure. ${ }^{26}$

\section{CONSTRUCTION OF THE LEGAL INDEX}

Various measures of investor friendliness have been developed in the literature, beginning with the widely-discussed research of LLSV in the late 1990s. These

\footnotetext{
23 The criticism of succumbing to 'Eurocentrism' in classifying the world according to common law, French, German, and Scandinavian legal origins (Glenn 2010) is then, of course, avoided.

${ }^{24}$ See below notes 97-100 for my allocation and LLSV 2008, pp. 1130-1131 for theirs.

${ }^{25}$ For an analysis of Portuguese company law and corporate governance see the Portugal country report in Gerner-Beuerle, Paech and Schuster 2013, pp. A783-A824, in particular pp. A786, 788.

${ }^{26}$ For a general analysis of Greek company law see the Greece country report in Gerner-Beuerle, Paech, and Schuster 2013, pp. A439-A474, and for the similarities with German law see Gerner-Beuerle and Schuster 2013.
} 
measures, however, are of limited use for purposes of this study because they seek to develop a comprehensive proxy for investor protection, taking into account both the statutory framework, the 'law on the books', and questions of enforcement, i.e. the law in practice. In contrast, this study does not assess the actual quality of investor protection in a legal system, and not even the level of investor protection engendered by the corporate governance codes, based on an evaluation of the effectiveness of the code provisions and compliance rates. Rather, since my aim is an examination of the political economy of corporate governance codes, it is sufficient to develop a proxy that captures the meaning of the code's text.

Therefore, the task is, on the one hand, easier than that of studies investigating the effect of the law on economic outcomes. On the other hand, corporate governance codes, as all regulatory measures, have to be seen against the backdrop of the whole regulatory architecture. Their content is influenced by what is and is not regulated in other parts of a country's legal system. Merely analyzing the codes would lead to incomplete observations and potential distortions. For example, if a particular legal mechanism is also (or exclusively) contained in the binding corporate law, we can expect the corporate governance code to be silent on the matter or address the issue imperfectly. However, the incompleteness of the code would not be indicative of a low level of investor protection. ${ }^{27}$ On the other hand, analyzing not only the codes, but also the statutory framework in a broad cross-section of jurisdictions creates formidable practical difficulties. For these reasons, I seek to develop a proxy for the level of investor protection that is imparted in a largely insulated manner by the codes themselves, instead of being a function of the interaction of statutory mechanisms and soft law. Such a proxy needs to satisfy the following conditions in order to be useful: (1) It must relate to a legal instrument that can be found in all corporate governance codes under investigation; (2) it must relate to an instrument that is sufficiently important to be representative of the degree of investor friendliness of the whole code; and (3) it must be sufficiently insulated from the codified corporate law to be, in itself, an accurate proxy for intended investor protection.

It is submitted that board structure regulation, for example the rules regarding the number of independent directors, separation of chairman and CEO, and the establishment of board committees, satisfies these requirements. Board structure regulation has been of central concern for policy-makers since the beginning of the corporate governance movement. It has been addressed by landmark initiatives in corporate governance and can indeed be found, in one way or another, in all codes in the sample. At the same time, functioning boards are an essential tool to protect investors against expropriation by managers. Directors' duties, the other main instrument employed by most jurisdictions, give rise to difficulties because they protect shareholders mainly ex post and require

27 Therefore, in contrast to existing research, for example Zanetti and Cuomo (2008), it is not useful to provide for an assessment of the full code. This is likely to result in an inaccurate proxy, unless the whole legal system is analyzed at the same time. 
enforcement (for an overview see Kraakman et al. 2009). ${ }^{28}$ A board that incorporates effective control mechanisms, on the other hand, makes self-serving behavior by managers more difficult and, therefore, protects investors ex ante, without the need to take recourse to enforcement. In addition, a well-functioning, balanced board ensures that the company is run successfully and profitably. Consequently, board structure regulation is an essential element of every investor protection regime. Finally, while the basic structure of boards is laid down in binding company legislation, we are interested in the more detailed aspects of board structure. How an effective board should be structured depends largely on the specificities of the company: industry, size of the company, and ownership structure. Therefore, in most jurisdictions, the issues examined here are not codified, but left to private ordering in the company's constitution, supplemented by the comply-or-explain precepts of corporate governance codes.

Nevertheless, it is necessary to be conscious that board structure regulation is embedded in the corporate governance model that the jurisdiction adopts. Most importantly, the definitions of the legal variables have to take account of the fundamental distinction between one-tier (unitary) board models consisting only of a board of directors and two-tier (dual) board models consisting of a management or executive board and a supervisory board. Both models can be found in European jurisdictions. In other respects, it may also be necessary to refer to the statutory rules. For example, in some countries, such as Denmark, ${ }^{29}$ the number of non-executive directors on the board is laid down in the companies legislation, whereas in others, such as the UK, the incorporators' contractual freedom how to structure the board is not constrained by binding legislation. Where necessary, I have, consequently, made allowance for statutory rules, but for the most part the relevant legal data for the proxy is confined to the corporate governance codes. The coding protocol contains references to statutory sources where appropriate.

I measure board structure on the basis of six specific issues, or elements, that have the potential to jeopardize the effectiveness of board control over management if not regulated appropriately: (1) the proportion of non-executive to executive directors on the board; (2) the number of independent directors; (3) the definition of independence; (4) the separation of the two central roles on the board, that of chairman and CEO; (5) the period of time the CEO has to wait after the end of his or her tenure before becoming chairman of the board ('cooling-off period'); and (6) the delegation of sensitive issues that involve particularly pronounced conflicts of interest to independent committees, namely succession planning, responsibility for the review of internal control procedures and the appointment of the external auditor, and remuneration decisions. I define

\footnotetext{
${ }^{28}$ Directors' duties are, in any case, laid down in statutory law and not dealt with by corporate governance codes.

${ }^{29}$ See Appendix B, n 23.
} 
these six elements so that the variables capture different board structure arrangements and assign a value between 0 and 1 to them, depending on how conducive the rule is to investor protection. A higher value indicates better investor protection. ${ }^{30}$

It is clear that the elements are not equally applicable to one-tier and two-tier boards. In jurisdictions with a two-tier board structure, executive and nonexecutive directors are by definition separated and the board ultimately responsible for monitoring, the supervisory board, consists entirely of non-executive directors, who may or may not be independent. Similarly, the positions of chairman of the supervisory board and chairman of the executive board (CEO in Anglo-American parlance) cannot be exercised by the same individual. Thus, elements (1) and (4) are not used in the calculation of the board structure index for jurisdictions that employ the two-tier board model. ${ }^{31}$ The difference between the one-tier and twotier board model requires additional modifications in the definition of the remaining four elements, which are, however, mostly of a terminological nature. For purposes of clarity separate definitions of the index elements are given for the two board models. ${ }^{32}$

Where the expectations of good corporate governance are somewhat openended, Commission Recommendation 2005/162/EC on the role of non-executive or supervisory directors of listed companies and on the committees of the (supervisory) board ${ }^{33}$ is used as a benchmark. This is particularly useful for elements (3) and (6), the definition of independence and the establishment of board committees to mitigate conflicts of interest. The Commission Recommendation provides for a definition of independence that is adopted with minor modifications. ${ }^{34}$ Codes that conform to the Recommendation's understanding of independence receive the value 1 for that element of the board structure index. The Commission Recommendation also expects corporations to establish three committees - nomination, remuneration, and audit committee and requires the committees to be composed of a majority, or exclusively, of nonexecutive directors, a majority of them being independent. ${ }^{35}$ The requirement applies to unitary as well as dual board models. Again, the variable is based on this benchmark with slight modifications.

The elements have been chosen because they constitute integral aspects of the control of management through a working corporate board. It is difficult to point to one or more of them as being more important than the others. Therefore, they receive equal weight. The total value of the variable measuring the investorfriendliness of codes (board structure variable) is the mean of the six or four

\footnotetext{
30 See Appendix A for the definitions.

31 Many jurisdictions offer their corporations a choice between one-tier and two-tier boards. However, in practice one model is always clearly preferred by corporations, often for historical reasons. I classify the jurisdiction as one-tier or two-tier based on these preferences. For details see Appendix B, Table B.1.

32 See Appendix A, Tables A.1 and A.2, for the one-tier and two-tier model, respectively.

33 See n 16 above.

34 Commission Recommendation 2005/162/EC, Annex II.

35 Commission Recommendation 2005/162/EC, Annex I.
} 
elements. Table 1 shows the scores received by the codes in the sample and the total value of the board structure variable. ${ }^{36}$

\section{[Table 1 about here]}

As discussed, code provisions are quantified in a two-step analysis. The first step (content-stage of the analysis) consists in a largely mechanical application of the definitions to the code provisions. The code provision receives the value corresponding to the applicable alternative of the definition. Since legal rules often contain exemptions, qualifications, or are phrased ambivalently, in a second step the provision is assessed qualitatively in light of the text of the section, its interaction with other provisions, and its strictness (or, conversely, the ease with which it may be circumvented). If appropriate, the value derived in the first step is then adjusted accordingly.

It may be useful to explain the operation of this two-step analysis with the help of an example. We take element (4), separation of CEO and chairman of the board, and analyze how the UK Corporate Governance Code of 2010 and the Italian Corporate Governance Code of 2011 correspond to the matrix developed here. The matrix and the two code provisions are as follows:

Element (4): Separation of chairman and CEO

Measured on a scale from 0 to 1 and shall be:

(a) 1 if the CEO and chairman are separated; the roles should not be exercised by the same individual;

(b) 0 if the same individual can be chairman of the board and CEO.

UK Corporate Governance Code 2010, A.2:

\section{Main Principle}

There should be a clear division of responsibilities at the head of the company between the running of the board and the executive responsibility for the running of the company's business. No one individual should have unfettered powers of decision.

\section{Code Provision}

A.2.1. The roles of chairman and chief executive should not be exercised by the same individual. The division of responsibilities between the chairman and chief executive should be clearly established, set out in writing and agreed by the board.

36 The abbreviations for the codes are explained below in Table 2. 
Italian Corporate Governance Code 2011, Article 2:

\section{PrinCIPLES}

2.P.4. It is appropriate to avoid the concentration of corporate offices in one single individual.

2.P.5. Where the Board of Directors has delegated management powers to the chairman, it shall disclose adequate information in the Corporate Governance Report on the reasons for such organisational choice.

\section{Criteria}

2.C.3. The Board shall designate an independent director as lead independent director, in the following circumstances: (i) in the event that the chairman of the Board of Directors is the chief executive officer of the company; (ii) in the event that the office of chairman is held by the person controlling the issuer.

\section{COMMENT}

The international best practice recommends to avoid the concentration of offices in one single individual without adequate counterbalances; in particular, the separation is often recommended of the roles of chairman and chief executive officer, the latter meant as a director who, by virtue of the delegations of powers received and the concrete exercise of these, is the main responsible officer for the management of the issuer (CEO). The Committee is of the opinion that, also in Italy, the separation of the above-mentioned roles may strengthen the characteristics of impartiality and balance that are required from the chairman of the Board of Directors. The Committee, in acknowledging that the existence of situations of accumulation of the two roles may satisfy, in particular in issuers of smaller size, valuable organizational requirements, recommends that, should this be the case, the figure of the lead independent director be created.

The UK code provides that there should be a clear division of responsibilities at the head of the company and the roles of chairman and chief executive should not be exercised by the same individual. This falls squarely within paragraph (a) of the definition of element (4). The provision is unambiguous and does not contain any qualifications or exceptions. Therefore, the UK Corporate Governance Code receives the value 1 for element (4) of the board structure variable.

The Italian code is different in several respects. First, it is phrased in more ambiguous terms. The concentration of the roles of chairman and CEO is not prohibited, but the code holds that it is 'appropriate' to avoid it. Code Principle 2.P.5 and Criteria 2.C.3 envisage that the company decides not to separate the two offices, but intends to ensure transparency and the existence of an appropriate counterweight in the form of a 'lead independent director' in case the same person 
acts as CEO and chairman. ${ }^{37}$ Finally, the comments, which are included in the code to clarify the principles and criteria, explicitly acknowledge that the accumulation of the roles of chairman and CEO may be beneficial and satisfy 'valuable organizational requirements'. Is this a prohibition of the concentration of corporate offices that warrants quantifying the Italian code pursuant to paragraph (a) of the definition of element (4)? Arguably, it is a prohibition because companies must give reasons in the corporate governance report if they concentrate the offices, which is in line with the essence of corporate governance codes. However, the quality of the prohibition is different from that of the UK code. Clearly, this is a difference that cannot be captured by a simple binary matrix and mechanical coding. At this point, the second, qualitative stage of coding becomes relevant.

At the second stage of coding, two aspects are of importance. First, is the code ambivalent, does it regulate by means of general guidelines that are open to interpretation and that can, accordingly, be evaded relatively easily, or does it give specific instructions and use clear prohibitions? Second, does the provision allow for exceptions? ${ }^{38}$ Since not all rules provide for exceptions and it is difficult to classify the precision of a legal rule as a free-standing variable, it is suggested that it is most accurate to adjust the value generated in the first step above (content) in light of the provision's precision and strictness. If the provision is unambiguous and does not allow for deviations (unless the company decides to deviate from the corporate governance code as such), the value generated in step 1 remains unaltered. If the rules contain exceptions that allow the company to disapply the best practice requirements without having to satisfy the basic transparency objective of corporate governance codes, the score received in step 1 is reduced by one-half. Code provisions that are phrased ambivalently and qualify the prohibition, but generally adhere to the comply-or-explain rationale of codes, stand between unequivocal prohibitions and rules allowing for exceptions. Such a case should, accordingly, generally lead to a reduction by 25 percent. ${ }^{39}$

The Italian code is an example for an ambivalent rule. It acknowledges the usefulness of the concentration of the roles of chairman and CEO and makes

\footnotetext{
37 The general regulatory goals are laid down in 'principles'; 'criteria' specify 'the recommended conduct typically necessary in order to reach the objectives set out in the principles'. See the Italian code, p. 6.

38 Corporate governance codes are, of course, by nature subject to an exemption in the sense that the corporation can decide not to comply (if it provides an explanation for the deviation from the code). However, what is meant here with 'exception' is the possibility granted by the code provision to avoid the governance requirements without formal deviation from the code.

${ }^{39}$ Codes are often similar in the way how they allow for exceptions or include ambiguous provisions. For example, several codes allow the board of directors to determine the independence of directors and, in doing so, deviate from the independence criteria laid down in the code. The wide discretion of the board is sometimes combined with the requirement of the directors to give reasons in the corporate governance report. Thus, it is possible to apply the adjustment of 25 percent consistently to all codes that grant the directors discretion but preserve transparency and the adjustment of 50 percent to all codes that do not ensure transparency, which is tantamount to incorporating an exception into the code. For individual explanations see the coding protocol, Appendix B.
} 
provision for the delegation of executive powers to the chairman within the framework of the code, i.e. the company is technically in compliance with the code if the offices are combined, even though transparency is required by virtue of the code. ${ }^{40}$ Therefore, it would be inappropriate to give the Italian code the same value that a code receives that prohibits the accumulation of the roles strictly and unambiguously, such as the UK code. This example shows that coding involves difficult questions of interpretation.

\section{OTHER DATA}

I construct data measuring the composition of corporate governance committees, the spread of benchmarks of good governance, the attractiveness of the code country for foreign investment and the development of the country's capital markets, and general characteristics of the issuer country's legal and political system.

In order to assess the composition of corporate governance committees, I have compiled information on the background and biographies of the individuals who sit on the committees. The data was hand-collected from open-access resources and in conversations with the code issuers. The individual committee members are allocated to three categories: issuer representative, investor representative, and neutral. Issuer representatives are individuals who serve, or have served, in an executive function on the board of public companies or who are affiliated with an association representing issuers, such as MEDEF (Mouvement des Entreprises de France), the French union of employers, representing a large number of French enterprises, or Confindustria, the organization representing Italian manufacturing and services companies. Investor representatives are individuals who work in the investment and asset management industry or are affiliated with associations representing investors, for example the Belgian Association of Pension Institutions (BAPI), Deutsche Schutzvereinigung für Wertpapierbesitz, the largest German private investors association, or the Dutch Association of Stockholders (VEB). Finally, committee members are classified as neutral if they cannot be seen as representing either of the two sides. This is in particular the case for independent professionals (for example, lawyers) or academics, or members of the public regulator. Representatives of financial institutions are somewhat ambivalent since financial institutions participate in the capital markets often both as issuers and investors. High-level representatives of such institutions, such as board members, however, will generally be concerned

${ }^{40}$ Code Provision 2.P.5. 
with the institution's role as an issuer, and they are classified accordingly as issuer representatives, unless evidence to the contrary can be found. ${ }^{41}$

Three alternative calculations of the composition of the drafting committee are provided to ensure that the results are not driven by computational issues. First, for each member who is an investor representative I assign the value 1, for a neutral member the value 0.5 , and for an issuer representative the value 0 . The score for each code is the sum of the values assigned to the individual members divided by the number of members. Second, the values 1 and 0 are assigned as before, but neutral members are excluded, except where all members of the committee are neutral, in which case the committee receives the value 0.5. In other cases, the variable equals the ratio of investor representatives to the sum of investor-affiliated and issuer-affiliated members. Third, the variable receives the value 1 if investor representatives have a majority on the drafting committee, the value 0 if issuer representatives have a majority, and the value 0.5 if issuers and investors are equally represented on the committee. Again, neutral members are not taken into consideration, except where the whole committee is neutral. Consequently, under all three methods of calculation, a higher value indicates that the committee should be investor-friendly. The author-variable should be positively correlated with the degree of investor-friendliness of the code if the committee members are successful in promoting the adoption of code provisions that favour their respective constituencies. The values for all corporate governance committees of the sample are given in Table 2 .

[Table 2 about here]

Two variables measure the spread of benchmarks of good governance and the evolution of the international debate on how firms should be governed (this is called 'sophistication' of the corporate governance debate). The underlying idea is that policy-makers may not only be influenced by their own convictions of what constitutes good corporate governance, but also by an emerging international consensus regarding governance principles or legal innovations. These innovations may be pioneered by a national policy-maker or an international organization and are then absorbed in other jurisdictions. Regulatory instruments, i.e. rules that address a real-life conflict, such as the managerial agency conflict, are disseminated through publications or discussions in international forums. They are considered by other policy-makers and, if accepted as suitable, may exert an influence on amendments of existing or the drafting of new regulation in jurisdictions other than the one from which they originated. In this way, regulatory instruments (or,

${ }^{41}$ The issuer/investor-orientation of the corporate governance committee, accordingly, also functions as a proxy for the influence of blockholders. In economies with concentrated ownership structure the interests of blockholders and issuers are aligned, which may explain the strong representation of issuerinterests on committees in countries such as Italy and France (AFEP/MEDEF-code), as opposed to the UK. 
more generally speaking, ideas or approaches to regulation) may be replicated and diffuse internationally.

Corporate governance codes are a good example for such a diffusion of regulatory ideas. First initiatives to improve corporate governance not by means of binding laws, but voluntary codes and the comply-or-explain principle stem from the United States and go as far back as the end of the 1970s (Business Roundtable 1978). They became practically important when large institutional investors, for example the Teachers Insurance and Annuity Association-College Retirement Equities Fund (TIAA-CREF) and the California Public Employees' Retirement System (CalPERS), started to issue principles of corporate governance and exercised their voting powers to change the governance structure of investee companies in line with their principles. In Europe, the corporate governance movement began in the early 1990s with the setting up of the Cadbury Committee, which was established by the UK Financial Reporting Council, the London Stock Exchange (LSE) and the accounting profession in response to a series of financial scandals. The committee published its report on 'the Financial Aspects of Corporate Governance' in December 1992, including a Code of Best Practice, the Cadbury Code. This was the first European corporate governance code and the first initiative to propose such essential reforms as, for example, the separation of the roles of chief executive and chairman of the board, the establishment of independence criteria, and the use of board committees. Successively, other European jurisdictions followed suit, and by the beginning of the new millennium most countries had corporate governance codes in place.

The processes of evolution and diffusion of legal ideas have been addressed in the literature, for example by Spamann (2009a), but this line of research is still in its early stages. I propose two alternative ways of modelling the development of the corporate governance movement and the understanding of what constitutes good governance. For the first method, the UK codes are taken as the European benchmark, given that this is how they are perceived in many European countries. ${ }^{42}$ Sophistication is measured as the level of investor-friendliness achieved by the UK code in force at the relevant time (the year before adoption of the code in question). 43 The second method assumes that the corporate governance debate becomes more sophisticated as time passes after a major regulatory initiative and the initiative is absorbed in other jurisdictions. I consider

\footnotetext{
42 See, e.g., Belgian Corporate Governance Recommendations, published by the Federation of Belgian Enterprises (1998), p. 3 ("The VBO/FEB has used, as the basis for its activities, the "Code of best practice" which has been recommended by the Cadbury Committee in the United Kingdom. These recommendations are very authoritative on an international level, and they are the result of activities which have been carried out at the initiative of Europe's leading stock exchange.'); Norwegian Code of Practice for Corporate Governance (2004), p. 6; Swiss Code of Best Practice for Corporate Governance (2008), p. 6.

${ }^{43}$ In 2005, EU Commission Recommendation 2005/162/EC was adopted (see n 16 above). Accordingly, for codes published thereafter, it can be assumed that both the UK code and the Commission Recommendation were seen internationally as important benchmarks. Therefore, beginning in 2006, I combine both sets of rules and take for each element of board structure the higher value as derived from the UK code or the Recommendation. See $\mathrm{n} 80$ below for the coding.
} 
the Cadbury Report of 1992 to be the main influence on the initial development of European corporate governance codes. The sophistication of the corporate governance debate is therefore also modeled as the time lag between publication of the Cadbury report and adoption of the respective code. This should give an approximate indication of the role played by the dissemination of major regulatory initiatives in the field.

In addition, I collect macro-economic data as indicators of the development of the issuer country's financial markets and the attractiveness of the country for foreign investors. Stock market capitalization is used as a proxy for the development of the capital markets. It is calculated as the product of the share price of listed companies (not considering investment companies, mutual funds, and other collective investment vehicles) and the number of shares outstanding. Net inflows of foreign direct investment, i.e. investments with the objective to acquire a lasting management interest (10 percent or more of voting stock) in an enterprise operating in the issuer country, and net inflows of portfolio equity investment, i.e. investments in equity securities by foreign investors below the threshold of direct investment, are used as proxies for the perception of the issuer country as an attractive destination for foreign investment and the relevance of the attitudes and expectations of foreign investors for policy-makers. The data comes from the World Bank World Development Indicators. Stock market capitalization and the equity flows are measured as a percentage of GDP. The three indicators exhibit significant variation from one year to the next caused by macro-economic shocks. In addition, it is unrealistic to assume that the code issuers were only influenced by the economic situation at the time of drafting and did not consider the financial development over several years. For these reasons, the average of the indicator in the year when the code was adopted and the previous four years is calculated for each variable. Another problem is posed by a number of outliers with high leverage that influence the results significantly. ${ }^{44}$ In order to address the problem, I perform robustness checks including and excluding the outliers.

Finally, I include several variables measuring relevant aspects of the country's legal and political system. As explained above, I classify the issuer countries' legal system according to the four main European legal families: common law and the French, German, and Scandinavian legal traditions. The classification is informed by the comparative legal literature, but I also deviate from this literature in some cases to take account of the main influence specifically on the countries' corporate law. ${ }^{45}$ I code dummy variables for each legal tradition. In addition, I include a dummy that is 1 if large public companies (the main addressees of corporate governance codes) are governed by a one-tier, unitary board and 0 if the law

${ }^{44}$ For example, portfolio equity investment in Luxembourg as a percentage of GDP is by several orders of magnitude larger than in the other countries. As a result, Luxembourg shifts the coefficient on portfolio equity investment up to 56 standard errors.

45 See above text to notes 22-26 and below Table 3 and notes 97-100 for the classification of legal families. 
provides for a dual, two-tier board structure. Where the legal system allows for a choice between one-tier and two-tier boards, which is the case in many jurisdictions in the French legal tradition, the country is coded according to which board model is preferred by the majority of companies in practice. ${ }^{46}$ While a dual board structure is particularly common in the German legal tradition and is mandatory in Austria, Germany, and Slovakia, the one-tier/two-tier distinction does not correspond to the dividing line between legal families. For example, in some German-origin jurisdictions it is possible to choose between the two models, whereas in the Netherlands, a French-origin country, the two-tier board is mandatory for large companies (so-called structuur vennootschappen). ${ }^{47}$ Since the legal variables have to be responsive to board structure, ${ }^{48}$ the unitary board dummy is a necessary control in the model. A second dummy receives the value 1 if the country's laws require one or more employee representatives on corporate boards. ${ }^{49} \mathrm{I}$ treat this variable as a proxy for the jurisdiction's responsiveness to the interests of employees. It would not be surprising if policy makers in a jurisdiction where the protection of employees has a long tradition were influenced by different considerations than policy makers in jurisdictions where this tradition is less pronounced. More specifically, the drafters of corporate governance codes may be less favorably disposed to strengthening the rights of investors if this means restricting the influence of the employees' voice on the board. ${ }^{50}$ Legal data for the unitary board and employee participation dummies is compiled from Adams and Kirchmaier (2013), Gerner-Beuerle, Paech, and Schuster (2013), and the website www.worker-participation.eu.

Three variables measure the political and policy-making climate in the issuer country. I include two political governance indicators from the World Bank Worldwide Governance Indicators: regulatory quality, defined as 'the ability of the government to formulate and implement sound policies and regulations that permit and promote private sector development', and government effectiveness, defined as 'the quality of public services, the quality of the civil service and the degree of its independence from political pressures, the quality of policy formulation and implementation, and the credibility of the government's commitment to such policies' (Kaufmann, Kraay, and Mastruzzi 2010). Corporate governance committees generally include representatives from government bodies, for example the financial market regulators, and failure of the government to provide for an effective regulatory environment may accordingly jeopardize the regulatory goals of the drafting process. I also construct a dummy variable

\footnotetext{
${ }^{46}$ For further discussion and a list of countries with one-tier and two-tier board models see Table 3 and Appendix B, Table B.1.

${ }_{47}$ The correlation coefficients for the unitary board dummy and the four legal traditions, common law, French, German, and Scandinavian, are $0.23,0.28,-0.63$, and 0.27 , respectively.

${ }^{48}$ See the discussion above, text to $n 29$.

49 See Table 3 below.

50 Again, the requirement to have employee representatives on the board is not simply a function of legal origins. The correlation coefficients for the employee representation dummy and common law, French, German, and Scandinavian legal origins are $-0.27,-0.47,0.22$, and 0.56 , respectively.
} 
recording the political orientation of the issuer country's government, since the political agenda of the government may have an impact on the codes' content. The dummy is 1 if the main governing party is social democratic and 0 if it is conservative (or advocating market liberalism). The three political variables are based on the situation in the year before publication of the code, which is assumed to be the time when a potential influence should have become relevant. The coding of the political dummy and the two legal dummies (unitary/dual board model and employee board representation) as well as the allocation of the countries in the sample to legal families are reported in Table 3.

[Table 3 about here]

\section{RESULTS}

Sample-level summary statistics of all variables in the dataset are provided in Table 4 (excluding the legal origins dummies but including the dummies for unitary/dual board model, employee board representation, and political orientation of the government). Table 5 compares the dependant variable measuring board structure regulation and the composition of corporate governance committees for selected observations. The individual legal elements of the board structure variable are analyzed in more detail in Table 6, Panels A and B. Panels C and D of Table 6 report summary statistics of the elements of board structure by legal tradition and compare the two methods of coding the legal variables, qualitative, interpretive assessment and simplified coding on the basis of a binary matrix.

[Table 4 about here]

We see large variation both in the legal variables and the three methods of calculating the affiliation of corporate governance committees. The measure of investor-friendliness of codes ('board structure') covers nearly the whole range of values that the variable can take, with a minimum of 0.013 (for the code promulgated by the Federation of Belgian Enterprises in 1998), a maximum of 0.925 (for the Dutch Code Tabaksblat of 2003 and subsequent codes), and a mean of 0.47 . Of the codes in the sample, 8 receive a score of 0.75 or more for board structure, 16 a score of 0.5 or more but less than $0.75,17$ a score of 0.25 or more but less than 0.5 , and 11 a score of less than 0.25 .

As far as the composition and affiliation of corporate governance committees are concerned, we find that three are exclusively composed of investor representatives (codes promulgated by the Association Française de la Gestion Financière - AFG and the Swedish Shareholders' Association) and three exclusively of issuer representatives (codes drafted by the Hellenic Federation of 
Enterprises and the Spanish Institute of Directors-Administrators). The other codes are a mix of issuer and investor representatives or are drafted by technocrats, for example stock exchanges. On average over the whole sample, 43 percent of committee members are issuer-affiliated, 39 percent are neutral, and only 18 percent investor-affiliated. ${ }^{51}$ If we exclude neutral members and concentrate on the ratio of issuer/investor representatives, we find that, over the whole sample, 71 percent of members are issuer-affiliated and 29 percent investoraffiliated. The same calculation at code-level and including the codes where all members of the committee are neutral (in which case the committee receives the value 0.5 ) results in a sample mean of 32 percent, which is the mean of the variable Authors2. The mean is lower compared to the first method of calculating committee composition (mean of 0.38 for Authors1) because the effect of neutral members is effectively removed.

A cursory examination of the data shows that at least in some cases the affiliation of the corporate governance committee does not seem to exhibit a strong correlation with the character of the code as investor-friendly or issuerfriendly. Table 5 reproduces a selection of observations underlining this point. The clearest example is probably France. The sample contains codes from two organizations, AFG, the French Asset Management Association, and AFEP/MEDEF, who represent the interests of French industry. 52 Not surprisingly, the composition of the AFG drafting committees is exclusively investor-oriented, while the AFEP/MEDEF committees are issuer-dominated. Nevertheless, the level of investor-friendliness achieved by the codes of different provenance is roughly comparable for the 1990s on the one hand (the MEDEF predecessor, the first Viénot report, is from 1995, the first AFG code is from 1998) and the first decade of the new millennium on the other hand (I use the MEDEF codes from 2003 and 2010 and the latest AFG code from 2011). It is also noteworthy that the scores for board structure received by the more recent codes are consistently higher. We can see this pattern in other countries as well, for example Belgium, Greece and Poland. In Italy and Sweden, some early corporate governance committees had a more balanced or investor-oriented composition than later committees. In Italy, the first corporate governance initiative, the report and code of conduct of 1999 ('Preda Code'), ${ }^{53}$ was prepared by a committee composed mostly of representatives of the industry, large public corporations and banks, but it was chaired by the chairman of the Italian Stock Exchange, Borsa Italiana, and included several academics and institutional investors. ${ }^{54}$ In contrast, the second Italian code in the sample, the corporate

\footnotetext{
51 These figures are almost identical if we calculate the proportion of issuer/investor representatives and neutral members on code-level, not sample-level. Now 42 percent of members are issuer-affiliated, 41 percent neutral, and 17 percent investor-affiliated.

52 Association Française des Entreprises Privées/Mouvement des Entreprises de France.

53 Comitato per la Corporate Governance delle Società Quotate, Report \& Code of Conduct, published October 1999.

${ }^{54}$ Of the 26 members in total, 15 are assigned to the issuer category, 3 to the investor category, and 8 are classified as neutral (members of the stock exchange, public accountants and lawyers, and academics).
} 
governance code of 2011, while also drafted under the auspices of the stock exchange, was chaired by the chairman of the board of Telecom Italia and had a clearer majority of issuer-affiliated members. ${ }^{55}$ In Sweden, the first comprehensive corporate governance guidelines were promulgated by the Swedish Shareholders' Association. Accordingly, this committee is coded as investor-affiliated. ${ }^{56}$ Later codes were prepared by a working group with members appointed fairly evenly by the government and different organizations in the business community representing both issuers and investors. Thus, in both countries later committees receive a lower score than the earlier drafting bodies, reflecting the shift towards a more issuer-oriented composition. In spite of this shift, the investor-friendliness of the codes has risen in both countries over the same time.

[Table 5 about here]

The development of both variables over time is shown in Figure 1. I calculate the values for the composition of corporate governance committees ('Authors') and the investor-friendliness of codes ('Board structure') by taking the mean of all codes in force at any given year. Thus, for each year I consider the scores received by codes adopted in earlier years in that country, but replace earlier codes if a new code is adopted by the same issuer in the relevant year. The graph shows clearly that the average investor-friendliness of codes has increased monotonically since 2000 , when the corporate governance movement gathered momentum, with one exception in 2006. The drop from 2006 to 2007 is due to the adoption of the Bulgarian code of 2007, the first code in that country, which had a board structure score of 0.2 , well below the average of 0.45 in 2006 . The composition of corporate governance committees, on the other hand, has remained largely constant.

[Figure 1 about here]

Table 6 presents summary statistics of the individual legal elements of the board structure variable and differences between legal traditions. Panel A reports the scores of the six elements of board structure. 'Cooling-off period' receives the lowest score on average over the sample. A possible explanation is that the requirement for the $\mathrm{CEO}$ not to become chairman of the board within a specified period of time constitutes a more recent legal innovation than the other elements. It was introduced in its strict form by the UK Combined Code of 2003 and the Dutch Tabaksblat Code of the same year, after the Higgs Report of January 2003 highlighted the dangers of a former chief executive serving as chairman of the

55 Of the 27 members, 19 are assigned to the issuer category, 3 to the investor category, and 5 are classified as neutral.

56 Sveriges Aktiesparares Riksförbund, Guidelines for better control and transparency for owners of companies quoted on the Swedish stock market, published 26 October 2001. 
board. ${ }^{57}$ However, even in the UK it has remained a controversial and not universally accepted principle (Davies and Worthington 2012, para. 14-75). Given the UK's leadership role in the field, it is maybe not surprising that the requirement is equally contentious in other countries and has not featured in their corporate governance codes until recently and even then only in some jurisdictions and in attenuated form. 58 The distinction between executive and non-executive directors, on the other hand, is well established and receives high scores in the majority of jurisdictions, with the highest sample mean and median of the six elements of board structure. It has been one of the central mechanisms to constrain the influence of executive directors and in particular the CEO ever since the Cadbury Report identified ineffective boards as one of the causes of a spate of financial scandals in the beginning of the 1990s (Davies and Worthington 2012, para. 14-71). It is instrumental in ensuring that boards function effectively and 'can both lead and control the business' (Committee on the Financial Aspects of Corporate Governance 1992, para. 4.2). This is reflected in the score for the "executive/non-executive" element received by the sample codes and the difference to the other elements.

The correlation table reported in Panel B shows that the six legal variables capture different aspects of board structure regulation. They are all positively correlated with each other, as we would expect, but the correlation is not so strong as to suggest that the elements are not meaningful individually. The statistically significant positive correlation between the number of independent directors and the definition of independence, separation of chairman and CEO, and committee structure is also not surprising. It is natural to regulate these issues together, not only the definition and number of independent directors, but also the other two variables, because the separation of chairman and CEO and the establishment of committees are more effective if the chairman and committee members are independent directors. We would, therefore, expect one variable to increase if the other increases as well. In general, the correlations indicate that if corporate governance reforms take place, they tend to tackle not only one or two of the issues measured by the six variables, but most of them together.

Panels $\mathrm{C}$ and $\mathrm{D}$ of Table 6 compare the six elements of the board structure variable by legal traditions. Panel $C$ summarizes the scores of the six elements and reports significance levels for the differences in the means of total board structure between common law and the other three legal traditions. In line with theory (for example, Djankov, La Porta, Lopez-de-Silanes, and Shleifer 2008; La Porta, Lopez-de-Silanes, and Shleifer 2008), we find that the means of French and German law are lower than common law. The difference is greater for the latter ( 0.35 for German origins vs. 0.47 for French origins and 0.6 for common law), and the German legal tradition has lower means in all of the six elements except

\footnotetext{
${ }^{57}$ Higgs 2003, p. 24.

58 Table 1 above shows that most countries started out with a score of 0 for 'cooling-off period' and some (but by no means all) then adopted some form of waiting period in the most recent code in the sample.
} 
the executive/non-executive distinction, which is only applicable to a subset of German origin countries. ${ }^{59}$ Notably, we can reject the hypothesis that the German and Common law means are equal with 95 percent confidence. The results are, however, less unequivocal than those of the aforementioned studies that found that the difference between French legal origins and common law was also significant. In addition, the data show that the Scandinavian legal tradition has higher means than common law in several of the indicators of investorfriendliness, which is not what we would expect in light of prior research.

Panel D contrasts the means of the elements of board structure after comprehensive, qualitative assessment of the code provisions with those obtained after simplified, binary coding as described above. ${ }^{60}$ The means after binary coding are higher for the full sample and the subsamples of all legal traditions than the means after qualitative coding, which is a result of the design of the binary matrix that conflates alternatives defined separately and, accordingly, receiving differentiated scores in the nuanced matrix into one category receiving the value 1.61 The positive difference does not, however, allow us to draw conclusions regarding the superiority of one coding method over the other. Rather, the fact that we can reject the hypothesis that the means of total board structure under both coding methods are equal with 99 percent and 95 percent confidence for the full sample and two of the subsamples, respectively (German and Scandinavian legal origins), shows that the two methods are not interchangeable, but the more nuanced approach captures additional information. Below I will discuss further whether the regression results are robust to the alternative coding methods and which model has the better fit.

[Table 6 about here]

Tables 7-11 examine empirically the determinants of corporate governance codes. Tables 7 and 8 contain the main regressions with two different measures of the diffusion of corporate governance innovations. Tables 9-11 report robustness checks using variations of the proxy for investor/issuer-orientation of corporate governance committees (the variable 'Authors') and the coding of the legal variables (qualitative assessment vs. binary coding). Furthermore, in Table 11 aggregate board structure is treated as a latent dependent variable and the elements of board structure are used as indicator variables in a structural equation model

\footnotetext{
59 The executive/non-executive element is applicable to jurisdictions with a unitary board structure, namely Switzerland, Greece, and Portugal. In particular, Switzerland with a score of 1 for the two codes of 2002 and 2007 ensures that the mean is fairly high.

${ }^{60}$ See above Section 3.

${ }^{61}$ For definitions of the nuanced matrix see Appendix A, Tables A.1 and A.2, and for the binary matrix Appendix B, Table B.7. Compare in particular the definitions below in Appendix B, notes 146-147 with those in Table A.1, elements (5) and (6).
} 
with a measurement part. All models are estimated by OLS with robust standard errors clustered at country level.

In Table 7, I regress the investor-friendliness of corporate governance codes on several sets of explanatory variables to examine the four hypotheses from above. First, investor-friendliness is regressed only on 'Authors1', the first method of computing the orientation of corporate governance committees. Second, I add a variable measuring the 'sophistication' of the corporate governance debate, which is here the score of investor-friendliness received by the UK benchmark code in force at the relevant time. Third, as economic controls I use (the logarithm of) the ratios of market capitalization and GDP, foreign direct investment (FDI) and GDP, and portfolio equity inflows and GDP. Fourth, I add successively the dummies for legal origins (omitting the dummy for common law), unitary vs. dual board, and employee representation at board level. Finally, I include three political variables, a dummy reflecting the political orientation of the governing party and variables measuring government effectiveness and regulatory quality. The sample includes all codes except the UK codes, since the latter are used as a regressor on the right hand side. For reasons explained below, I also exclude the Luxembourg code of 2006 for all regressions except (7). Therefore, in regressions (1)-(6) the sample contains a total of 47 corporate governance codes, stemming from all legal families and following both the one-tier and two-tier board model.

[Table 7 about here]

As already suggested by the graphical representation in Figure 1 above, we do not find a statistically significant relationship between investor-friendliness and the investor/issuer-orientation of the drafting committees under most model specifications. The coefficients on 'Authors1' are generally of low magnitude and with a low t statistic. ${ }^{2}$ The only exception is equation (3) of Table 7, where we can reject the hypothesis that the coefficient is 0 with 95 percent confidence. ${ }^{63}$ The coefficient is positive, which is in line with the first hypothesis. A committee that is investor-oriented is associated with a higher level of investor-friendliness of the code. This is furthermore corroborated by anecdotal evidence. Members of corporate governance committees confirm that interest groups on drafting committees have regulatory preferences that they seek to promote. However, it is necessary to treat these estimates with caution. First, the same specification with the three economic controls, but the alternative definition of 'sophistication' or the binary version of the dependent variable, does not show a statistically significant influence of the composition of corporate governance committees. Second, theory suggests that the general legal environment is relevant for the

${ }^{62}$ In the model with the best fit, equation (5) of Table 7, the t statistic is 0.2 and the p-value 0.843 .

63 The result holds for the other two calculations of the investor/issuer-orientation of committees, variables 'Authors2' and 'Authors3'. In each case, the composition of the committee is statistically significant at the 5 percent level. Regression estimates are reproduced below in Table 9, columns (7) and (8). 
content of corporate governance codes, since the drafters, who are often legal experts, develop the code provisions against the backdrop of the country's legal system. A model that does not take account of the legal environment gives rise to omitted variable concerns. Third, a model with the legal variables added as regressors has indeed a considerably better fit than regression (3). ${ }^{64}$ Figure 2 plots the residuals from a partial regression of board structure against the residuals from regressing committee composition, including as controls the three economic variables and the five legal variables (regression (5) of Table 7). Under this specification, committee composition is clearly not associated with board structure (i.e. the level of investor-friendliness of the code).

[Figure 2 about here]

On the other hand, the UK benchmark codes in force at the relevant time, used as a proxy for the sophistication of internationally recognized corporate governance initiatives, are positively associated with the level of investor-friendliness of the codes issued by other countries. The relationship is statistically significant at the 1 percent level under all model specifications, including different calculations of the investor/issuer-orientation of the drafting committees and the binary coding of the response variable. The coefficient is economically large; a one-unit increase in the level of investor-friendliness of the UK code translates into a 0.54 to 0.62 -unit increase in the level of investor-friendliness of subsequent codes from other countries. Expressed in standardized coefficients, the investor-friendliness of UK codes has the largest coefficient. For example, in specification (3), a one standard deviation increase in 'Sophistication' is associated with a 0.53 standard deviation increase in the predicted level of investor-friendliness of subsequent codes, which is a stronger effect than that of any other variable. In specification (5), the dependent variable increases by 0.49 standard deviations and in specification (7) by 0.54 standard deviations if 'Sophistication' increases by one standard deviation, which is again larger than the effect of any of the other quantitative explanatory variables (not considering the dummies). Figure 3 shows the influence of individual observations on the coefficient estimates (based on equation (5) in Table 7). The observation in the upper right-hand corner is the Greek code of 2011, the observation in the lower right-hand corner the Bulgarian code of 2007, and the observation at the bottom to the left the Belgian code of 1998 issued by the Federation of Belgian Enterprises. ${ }^{65}$ If we exclude these three observations,

\footnotetext{
${ }^{64}$ Both the Akaike information criterion (AIC) and the Bayesian information criterion (BIC) indicate a significantly better fit of regression (5) with an AIC of -29.92 and a BIC of -9.57 , compared with -18.34 and -7.24 , respectively, for regression (3).

${ }^{65}$ Not identical with the 1998 code issued by the Belgian Corporate Governance Committee, which is also in the sample.
} 
which have the largest influence on the estimate, ${ }^{66}$ the coefficient on 'Sophistication' remains statistically significant at the 1 percent level.

[Figure 3 about here]

The economic controls are not statistically significant, with the exception of portfolio equity net inflows, which is positively associated with the investorfriendliness of the response code. This is intuitive; we would expect investors who do not intend to acquire a major stake, but only a minority holding giving them limited or no influence on the management of the company, ${ }^{67}$ to be particularly anxious to promote legal devices strengthening the control of management, such as those captured by the board structure variable. The effect of portfolio equity net inflows is, however, relatively small compared to that of the UK benchmark codes. A one standard deviation increase in portfolio equity net inflows is associated with a 0.16 standard deviation increase in the level of investorfriendliness of corporate governance codes. ${ }^{68}$ In addition, the estimates are sensitive to the inclusion of individual observations. The regressions in columns (1) to (6) of Table 7 do not include the Luxembourg code of 2006. Inclusion of the Luxembourg code does not have an effect on the significance levels of 'Sophistication', German legal origins, and unitary boards. It does, however, change the sign of the coefficient on portfolio equity inflows and render the coefficient insignificant. The reason is that in the case of Luxembourg, because of its attractiveness to foreign investors and the small size of its economy, portfolio equity inflows as a percentage of GDP are by several orders of magnitude larger than for any other country in the sample. ${ }^{69}$ Since the influence of the Luxembourg code on the estimates is very significant, ${ }^{70} \mathrm{I}$ exclude the code from the main regressions and the robustness checks. Without Luxembourg, the relationship between portfolio equity inflows and the investor-friendliness of codes is significant for most specifications, as shown by Figure 4.

[Figure 4 about here]

Of the legal and political variables, only the German legal origins dummy and the unitary board dummy are statistically significant, at least as long as 'Sophistication' is measured as the level of investor-friendliness of the UK benchmark codes. German legal origin is significant at the 1 percent level for all model specifications.

66 The Belgian code of 1998 shifts the coefficient on 'Sophistication' 0.50 standard errors, the Bulgarian code of 20070.51 standard errors, and the Greek code of 20110.44 standard errors.

67 The investment would therefore not qualify as foreign direct investment as defined by the World Bank. For a description of the economic variables see above Section 5.

68 The raw data is on a different scale than that of the other two economic variables because the log transformation required a preceding transformation to eliminate negative values (i.e. net outflows of portfolio investments).

69 See above $n 44$.

70 If we regress board structure on portfolio equity inflows and the other controls as specified in equation

(5), the Luxembourg code shifts the coefficient on portfolio equity inflows 37 standard errors. 
Codes from common law jurisdictions can be expected to have a level of investorfriendliness that is between 0.22 and 0.33 (on a scale from 0 to 1) higher than codes from countries belonging to the German legal tradition, everything else held constant. We should, however, be careful with the conclusions that we draw from this observation. The coefficient estimates merely highlight that codes in the German legal tradition tend to be less concerned than common law codes with the strategies for the protection of investors embodied in the definitions of the six legal variables used to assess investor-friendliness. For example, codes in the German legal tradition tend to define 'independence' in general terms, rather than drawing up a list of criteria as in Commission Recommendation 2005/162/EC, and consequently receive a relatively low score. The estimates do not allow us to assess the level of investor protection on the whole in the respective jurisdiction. In particular, if it is correct, as has been pointed out in the literature (Cools 2005), that substitute mechanisms exist in civil law countries, for example strong decision rights of shareholders, the comparatively low level of investor-friendliness of German legal origin codes may simply be an expression of the fact that investor protection is achieved through different channels.

As far as the coefficient on 'unitary board' is concerned, the estimates are mainly driven by one country: the Netherlands (see Figure 5). ${ }^{71}$ This explains the possibly surprising result that jurisdictions providing for a unitary board model tend to produce codes with a lower level of investor-friendliness than dual board jurisdictions. In general (but not always ${ }^{72}$ ), countries in the German legal tradition follow the two-tier board model and the other legal traditions the one-tier model, which would lead us to expect that the coefficient on 'unitary board' should be positive. However, the Netherlands, a jurisdiction that has traditionally placed great emphasis on investor protection and whose codes receive the highest score for investor-friendliness of the whole sample, requires large companies to form a two-tier board. Without the two Dutch codes, the coefficient is still negative, but no longer significant.

[Figure 5 about here]

How should these results be interpreted? The clearest finding is that corporate governance codes that are internationally recognized as establishing benchmark rules of good governance are highly influential on the content of new codes or the reform of existing codes in other jurisdictions. The investor/issuer-orientation of drafting committees, on the other hand, is on balance not statistically significantly associated with the level of investor-friendliness of codes. Rather than attempting to engage in regulatory arbitrage by offering advantageous conditions to their constituencies, policy-makers seem to be motivated by the desire to emulate

71 The Dutch code of 2003 shifts the coefficient nearly by one standard error.

${ }^{72}$ See above text to $n 47$. 
internationally accepted standards of good governance. Differences in a jurisdiction's legal environment also engender different approaches to designing principles of good governance, with codes belonging to the French and German legal traditions being less investor-friendly than common law codes. The statistical significance of the relationship between some of the legal traditions and the investor-friendliness of corporate governance codes is not surprising, given that codes are developed within a broader legislative framework and code provisions interact with this framework, for example where they reflect the one-tier/two-tier board structure distinction. ${ }^{73}$ But the findings do not allow us to draw any conclusions regarding the overall disposition of a jurisdiction towards issuer or investor interests. Furthermore, the insignificant coefficients on French legal origins show that we cannot confirm the claim that inherent differences between common law and civil law have an effect on the level of investor-friendliness of a jurisdiction (see La Porta, Lopez-de-Silanes, and Shleifer 2008). The scores for individual codes and summary statistics from above illustrate this. ${ }^{74}$ While the scores received by the German codes, compared with the UK codes, ostensibly corroborate the claim that the common law is favourably inclined towards investor protection, the Scandinavian countries, but also the Belgian, French, and Spanish codes, show that civil law countries are perfectly capable of producing investorfriendly rules.

I modify the calculation of some variables and the model specifications to check the robustness of these findings. Table 8 reports estimates of the same regressions as Table 7 , but now the international diffusion of corporate governance innovations is modeled as the time lag between the first comprehensive corporate governance initiative in Europe, the Cadbury Report of 1992, and the adoption of the response code. ${ }^{75}$ The results by and large confirm the findings from above. In particular, the coefficient on 'Sophistication' continues to be positive and statistically significant at the 1 percent level throughout. Again, exclusion of the codes with the highest leverage as shown in Figure 6 does not change the significance level. The level of investor-friendliness increases per year by around 0.03 in absolute terms or by 9.7 percent. Portfolio equity inflows are also significant but sensitive to the inclusion of the Luxembourg code (regression (7) of Table 8). Now both French and German legal origins are statistically significant at the 5 and 1 percent level, respectively, with a higher negative coefficient, i.e. a lower level of investor-friendliness compared with common law codes, for German origin codes. However, the same caveat applies as above. The negative coefficient reflects differences in the approach to regulating by means of

\footnotetext{
${ }^{73}$ Notably, the variables measuring the distinction between executive and non-executive directors and the separation of chairman and CEO are not applicable to two-tier board model jurisdictions, which are most jurisdictions in the German legal tradition. This can be expected to influence the results.

74 Tables 1 and 4.

${ }^{75}$ Luxembourg is again excluded (except for regression (7)), but the four UK codes included so that we have 51 observations.
} 
(non-binding) corporate governance codes, but not necessarily deficiencies in the level of investor protection in the legal system as a whole.

[Table 8 and Figure 6 about here]

In Tables 7 and 8 the model with the best fit is regression (5). ${ }^{76} \mathrm{I}$ therefore take this model and vary the calculation of the investor/issuer-orientation of corporate governance committees as described above. ${ }^{77}$ Table 9 reports the estimates. All results are robust to the different calculations of the investor/issuer-orientation of the committee ('Authors') as regards both economic magnitude and significance levels. I also use specification (5) from Tables 7 and 8 to check robustness of the findings to a binary, as opposed to nuanced, coding of the legal variables. The coefficient estimates are reported in Table 10. The magnitude of the coefficients changes and the investor/issuer-orientation of committees is not significant under any specification, but the two variations of 'Sophistication' and German and French legal origins remain significant. Importantly, the model fit is consistently not as good as in Tables 7-9, suggesting that nuanced coding captures the variation in the content of the codes better than binary coding.

Finally, I use a structural equation model to test whether the aggregate board structure variable is a good proxy for the investor-friendliness of codes. I treat investor-friendliness as a latent variable and the four elements of board structure that apply to all jurisdictions as indicator variables. ${ }^{78}$ Panel A of Table 11 reports estimates for a single-factor confirmatory model. The factor loadings are all statistically significant at the 1 or 5 percent level ${ }^{79}$ and the common factor explains the variance in the indicators reasonably well (with some reservations concerning 'cooling-off period'). Panel B shows that the model fit is very good. The differences between the fitted correlation matrix and the correlations calculated from the sample are small. In a second step, I run regressions (5) from Tables 7 and 8, i.e. the first version of measuring the investor/issuer-orientation of the drafting committees and the two methods of calculating 'Sophistication' with the four elements of board structure used in the confirmatory factor analysis as endogenous indicators of the investor-friendliness of codes and economic and legal controls. ${ }^{80}$ The structural model confirms all results. The investor/issuer-

\footnotetext{
${ }^{76}$ Model fit is judged by means of the Akaike information criterion (AIC) and Bayesian information criterion.

77 Section 5.

78 These are: number of in-dependent directors; definition of independence; cooling-off period for the $\mathrm{CEO}$; and committee structure.

${ }^{79}$ The p-value for "cooling-off period" is 0.11 .

80 The measurement part is therefore of the form:

$$
y_{i}=\alpha_{i 0}+\alpha_{i 1} \eta+\varepsilon_{i}
$$

where $y_{i}, i=1, \ldots, 4$ are the endogenous observed variables (the four elements of board structure as discussed in the text), $\eta$ is the endogenous latent variable "investor-friendliness", $\alpha_{i, j}$ are the intercepts and coefficients, and $\varepsilon_{i}$ the error terms. The structural part is of the form of a general regression equation:
} 
orientation of committees is not significant, but the diffusion of corporate governance initiatives, portfolio equity inflows from abroad, and French and German legal origins are.

[Tables 9-11 about here]

\section{CONVERGENCE}

It has been a longstanding claim that corporate governance systems, and corporate law in general, converge. Famously, Hansmann, and Kraakman (2000) have argued that corporate law systems exhibit a tendency towards 'a single, standard model' of corporate governance informed by Anglo-American legal solutions. This claim has not remained unchallenged (see, for example, Kershaw 2002), and it has been suggested alternatively that the social forces that shape legal rules, for example corporate ownership structures, impede convergence because they depend in part on the structures that an economy had at earlier times (Bebchuk and Roe 1999). On this view, legal systems are path-dependent and legal differences are likely to persist.

It is clear that jurisdictions learn from each other in the sense that policymakers interact in various informal or institutionalized ways, exchange information, and are aware of regulatory initiatives stemming from other jurisdictions. ${ }^{81}$ The realization that such an international flow of legal ideas takes place is, of course, an essential feature of the theoretical framework proposed here, since I argue that certain regulatory initiatives can be seen as benchmark rules (here the UK codes) that influence the process of rule-making in other countries. If the convergence claim is understood to mean that legal systems move towards a particular level of regulation, for example the level of investor protection achieved by Anglo-American law, the findings of this study confirm the claim. As shown, the average level of investor-friendliness of codes increases over the sample period, and this increase is associated with a high level of investorfriendliness of the UK benchmark codes. Such convergence may be termed 'outcome convergence' since the outcome of a set of legal rules (here quantified as 'level of investor-friendliness') approaches, on average, that of benchmark rules.

$$
\eta=X \beta+u
$$

where $X$ is a matrix that contains the regressors and $\beta$ and $u$ vectors containing the coefficients and error terms.

${ }^{81}$ This is true at the international level and even more so within the EU. See, for example, Commission Decision 2004/706/EC of 15 October 2004 establishing the European Corporate Governance Forum, OJ L 321 of 22.10.2004, p. 53, noting explicitly that the Forum "should serve as a body for exchange of information and best practices existing in Member States in order to enhance the convergence of national codes of corporate governance as well as a body for reflection, debate and advice to the Commission in the field of corporate governance." Ibid., recital 6. 
However, convergence may also be defined more ambitiously as the evolution of legal systems towards a standard set of rules. Defined this way, convergence requires not only that legal systems achieve regulatory effects approaching a benchmark. It is also not sufficient to show that particular legal innovations are transmitted across borders and absorbed by foreign jurisdictions. ${ }^{82}$ Rather, convergence in the strict sense occurs if the regulatory techniques employed by different jurisdictions across a whole legal area become increasingly similar. In order to assess this claim, it is useful to develop a formal measure of convergence. If legal rules have been quantified and a cross-section of legal indices computed, a natural candidate to measure convergence is the variance of the legal variable. In Table 12, mean and variance of the board structure variable are analysed in different ways to examine whether corporate governance models converge in the strict sense.

[Table 12 about here]

I first divide the sample into two subsamples, the first one comprising codes adopted between 1998 and 2004 and the second one codes adopted between 2005 and 2011. Panel A reports the mean and median of 'Board structure' and the investor/issuer-orientation of the drafting committees for the two subsamples and the estimates of a paired mean equality test. As we would expect, the mean and median of the board structure variable are statistically significantly higher in the second subsample, but not those of investor/issuer-orientation. In Panel B, I compare the standard deviation of both variables for the two subsamples. The standard deviations are slightly smaller, but the difference is not significant. Next, I compute the standard deviation of codes in force in any given year, i.e. I discard codes that have been superseded by a newer code from the same issuer. If convergence in the strict sense occurs, and the convergence claim also holds for the legal mechanisms analyzed here, we would expect the standard deviation to decrease over time. However, Panel $\mathrm{C}$ shows that while mean and median of the board structure variable increase (as we already saw in Figure 1 above), the variance remains fairly constant. This means that codes influence each other by reinforcing a trend towards a higher level of investor-friendliness, but they do so with mechanisms that differed as much in the beginning of the sample period as they do today. Finally, in Panel D I calculate on a rolling basis mean and variance of codes newly adopted in the last three years. I then contrast the means of the new codes with those of the codes in force in the relevant year. The intuition is the same as before. If corporate governance models converge, the variance of the new codes and difference in means should decrease. However, again the data does not substantiate the strict convergence hypothesis. The variance and difference

82 This phenomenon has been discussed widely in the literature on convergence and path dependence. 
fluctuate over time, but there is no clear trend towards smaller variance or difference.

A possible explanation is that the benchmark system, the UK, is an outlier in the sample. European jurisdictions are dominated by the French and German legal traditions and traditionally only the laws of Cyprus and Malta were closely aligned with English law. Therefore, it is not surprising that the reception of legal innovations stemming initially from the UK does not lead to a decrease in the variation of legal techniques or even results in greater variance, at least in the short run. Diversity within a legal family increases as jurisdictions move away from their 'old' standard model of corporate governance. They do so at different times and with different speeds and often do not implement the foreign legal innovation faithfully, but modify it to reconcile it with their own legal tradition. Thus, the transmission of legal ideas from other traditions does not immediately give rise to a new standard model, and it is unclear whether and when it will do so in the context examined here. For now, a standard model of corporate governance characterized by largely similar rules has not emerged in Europe. Considerable differences remain in the techniques of board structure regulation, even though a trend towards more investor-friendly codes is discernible.

In summary, the lesson to be taken away from the analysis is that the transmission of legal concepts across borders and the evolution of regulatory outcomes towards a benchmark do not necessarily result in convergence in the strict sense, i.e. the use of increasingly similar regulatory techniques across a whole set of rules (a legal system or subsystem). Jurisdictions influence and learn from each other, but convergence, modelled formally as the lower variance of a legal variable over time, may nevertheless not occur.

\section{CONCLUSION}

In this article, I model the political economy of corporate governance codes as a linear relationship between the level of investor-friendliness of corporate governance codes, the composition of the committees that draft the codes, the international spread of corporate governance initiatives and benchmark codes, and economic and legal conditions in the issuer country. The approach taken here is in several respects different from existing studies. First, I construct a detailed proxy for the investor-friendliness of the 52 codes in the sample by analysing and quantifying representative code provisions. In order to ensure the robustness of the coding process, I use two approaches to quantification, a nuanced, comprehensive interpretation of the legal provisions and simplified, binary coding. Second, the drafting committees are not simply classified according to the identity of code issuers, but the affiliation of each individual on the committee is recorded and hereby the political orientation of the drafting committee (as investor or issuer-oriented) computed. Third, it is generally accepted that certain countries are 
at the forefront of corporate governance reform and policy-makers in other jurisdictions are well aware of the initiatives emanating from the innovating country. In Europe, the most influential jurisdiction in this respect is the United Kingdom. I therefore suggest two methods of modeling the dissemination of legal ideas in the field of corporate governance. The first is to quantify the legal innovations in the same way as the response codes (the legal proxy used as dependent variable) and assess empirically how the former are associated with the latter. The second is to include a time trend starting with the legal innovation to capture the development of codes over time.

I hypothesize that the main determinants of corporate governance reform include: (1) the diffusion of an international benchmark model of corporate governance; (2) approaches to corporate governance and the protection of different stakeholders embodied in a country's legal system; (3) the desire to attract foreign investors and strengthen the domestic capital market; and (4) the influence of interest groups on the drafting process. I find strong evidence that the international diffusion of principles of good governance (defined as the investorfriendliness of the UK codes and the distance in years between the first comprehensive UK corporate governance initiative, the Cadbury Report of 1992, and the adoption of the response code) is positively correlated with the level of investor-friendliness of the response codes. The drafters of codes seem to emulate internationally accepted standards of good governance. As regulatory initiatives (in the form of complete codes or specific provisions that embody novel approaches to addressing corporate governance conflicts) become publicly available, they are studied and, if found convincing, replicated. In this way, an above-average level of investor-friendliness of some foreign codes exerts pressure on the national policymaker to meet the international standard, thus creating a self-enforcing trend towards higher average levels.

I also find strong evidence that codes belonging to the German legal tradition (and, to a lesser extent, those belonging to the French legal tradition) tend to exhibit statistically significantly lower levels of investor-friendliness than common law codes. However, these findings do not allow us to draw any conclusions regarding the level of investor protection in the respective jurisdiction as a whole. Legal mechanisms contained in the binding company laws of German or French origin jurisdictions may operate as functional substitutes for less investor-friendly rules in the non-binding codes. On this view, the statistically significant relationship is an expression of different regulatory techniques, rather than different levels of investor protection. Binding rules may substitute for nonbinding ones and mechanisms not related to board structure (such as direct decision rights of shareholders) may substitute for board structure regulation.

I find some evidence that portfolio equity inflows are an indicator of the investor-friendliness of codes, but the estimates are sensitive to which countries are included in the sample. The intuition, in any case, is clear. A strong presence of international investors in the country may induce corporate governance 
committees to be more sensitive to the expectations of these investors and, thus, receptive to widely accepted principles of good governance and investor protection.

Under most model specifications, the investor/issuer-orientation of corporate governance committees is not statistically significantly associated with the level of investor-friendliness. While anecdotal evidence indicates that interest groups attempt to promote the interests of their constituencies, in a multiple linear regression model the influence of the affiliation of committee members is insignificant next to other explanatory factors. The findings, therefore, add a (formal) dimension to the literature on interest group politics. As the international diffusion of corporate governance best practices evolves, committee members base their policy-making decisions predominantly on these initiatives as a benchmark, irrespective of their affiliation.

Finally, I test the claim that corporate governance systems converge towards a single, standard governance model. Modelling convergence/divergence formally as the development of the variance of a legal variable over time, I do not find any evidence supporting the convergence hypothesis. This means that the international diffusion and transplantation of legal ideas, which is a well-documented phenomenon, and the convergence of sets of legal rules should be distinguished, at least if convergence is understood formally. 


\section{References}

Adams, Renée B., and Tom Kirchmaier. 2013. Making It to the Top: From Female Labor Force Participation to Boardroom Gender Diversity. ECGI Finance Working Paper No. 347/2013. Available at: http://ssm.com/abstract $=2192918$.

Aguilera, Ruth V., and Alvaro Cuervo-Cazurra. 2004. Codes of Good Governance Worldwide: What is the Trigger? Organization Studies 25:417-445.

Aguilera, Ruth V., and Alvaro Cuervo-Cazurra. 2009. Codes of Good Governance. Corporate Governance: An International Review 17:376-387.

Andres, Christian, and Erik Theissen. 2008. Setting a fox to keep the geese - Does the comply-or-explain principle work? Journal of Corporate Finance 14:289301.

Arcot, Sridhar, Valentina Bruno, and Antoine Faure-Grimaud. 2010. Corporate governance in the UK: Is the comply or explain approach working? International Review of Law and Economics 30:193-201.

Armour, John, Simon Deakin, Viviana Mollica, and Mathias Siems. 2010. Law and Financial Development: What We are Learning from Time Series Evidence. Brigham Young University Law Review 2010:1435-1500.

Armour, John, Simon Deakin, Prabirjit Sarkar, Mathias Siems, and Ajit Singh. 2009. Shareholder Protection and Stock Market Development: An Empirical Test of the Legal Origins Hypothesis. Journal of Empirical Legal Studies 6:343-380.

Armour, John, Simon Deakin, Priya Lele, and Mathias Siems. 2009. How do legal rules evolve? Evidence from a cross-country comparison of shareholder, creditor, and worker protection. American Journal of Comparative Law 57:579629.

Armour, John, and David A. Skeel, Jr. 2007. Who Writes the Rules for Hostile Takeovers, and Why?--The Peculiar Divergence of U.S. and U.K. Takeover Regulation. Georgetown Law Journal 95:1727-1794.

Bebchuk, Lucian A., and Zvika Neeman. 2010. Investor Protection and Interest Group Politics. Review of Financial Studies 23:1089-1119.

Bebchuk, Lucian A., and Mark J. Roe. 1999. A Theory of Path Dependence in Corporate Ownership and Governance. Stanford Law Review 52:127-170.

Bebchuk, Lucian A., and Michael S. Weisbach. 2010. The State of Corporate Governance Research. Review of Financial Studies 23:939-961.

Business Roundtable. 1978. The Role and Composition of the Board of Directors of the Large Publicly Owned Corporation. Business Lanyer 33:2083-2113.

Cheffins, Brian R. 2001. Does Law Matter? The Separation of Ownership and Control in the United Kingdom. Journal of Legal Studies 30:459-484.

Committee on the Financial Aspects of Corporate Governance (Cadbury Committee). 1992. The Financial Aspects of Corporate Governance (Cadbury Report). Available at: http://www.ecgi.org/codes/documents/cadbury.pdf.

Coffee, John C. 2001. The Rise of Dispersed Ownership: The Roles of Law and the State in the Separation of Ownership and Control. Yale Law Journal 111:1-82. 
Cools, Sofie. 2005. The Real Difference in Corporate Law between the United States and Continental Europe: Distribution of Powers. Delaware Journal of Corporate Law 30:697-766.

Davies, Paul, and Sarah Worthington. 2012. Gower and Davies' Principles of Modern Company Law. 9th ed., Sweet \& Maxwell.

Djankov, Simeon, Rafael La Porta, Florencio Lopez-de-Silanes, and Andrei Shleifer. 2008. The law and economics of self-dealing. Journal of Financial Economics 88:430-465.

Engert, Andreas, and D. Gordon Smith. 2009. Unpacking Adaptability. Brigham Young University Law Review 2009:1553-1570.

Ferran, Eilis. 2011. After the crisis: the regulation of hedge funds and private equity in the EU. European Business Organization Law Review 12:379-414.

Gerner-Beuerle, Carsten, Philipp Paech, and Edmund-Philipp Schuster. 2013. Study on directors' duties and liability, prepared for the European Commission DG Markt. Available at: http://ec.europa.eu/internal_market/company/board/index_en.htm.

Gerner-Beuerle, Carsten, and Schuster, Edmund-Philipp. 2013. Mapping Directors' Duties: Strategies and Trends in the EU, in: Hanne Birkmose, Mette Neville \& Karsten Engsig Sørensen (eds.). Boards of Directors in European Companies, Kluwer Law International.

Glenn, Patrick. 2010. Legal Traditions of the World. 4th ed., Oxford University Press.

Gompers, Paul A., Joy L. Ishii, and Andrew Metrick. 2003. Corporate Governance and Equity Prices. Quarterly Journal of Economics 118: 107-155/

Hansmann, Henry, and Reinier Kraakman. 2000. The End of History for Corporate Law. Georgetown Law Journal 89:439-468.

Higgs, Derek. 2003. Review of the role and effectiveness of non-executive directors, prepared for the UK Department of Trade and Industry. Available at: http://www.ecgi.org/codes/documents/higgsreport.pdf.

Kaufmann, Daniel, Aart Kraay, and Massimo Mastruzzi. 2010. The Worldwide Governance Indicators: Methodology and Analytical Issues, World Bank Policy Research Working Paper No. 5430. Available at: http://ssrn.com/abstract $=1682130$.

Kershaw, David. 2002. No end in sight for the history of corporate law: the case of employee participation in corporate governance. Journal of Corporate Law Studies 2:34-81.

Kraakman, Reinier et al. 2009. The Anatomy of Corporate Law. A Comparative and Functional Approach. 2nd ed., Oxford University Press.

La Porta, Rafael, Florencio Lopez-de-Silanes, and Andrei Shleifer. 2008. What Works in Securities Laws? Journal of Finance 61:1-32.

La Porta, Rafael, Florencio Lopez-de-Silanes, and Andrei Shleifer. 2008. The Economic Consequences of Legal Origins. Journal of Economic Literature 46:285-332.

La Porta, Rafael, Florencio Lopez-de-Silanes, Andrei Shleifer, and Robert Vishny. 1997. Legal Determinants of External Finance. Journal of Finance 52:11311150.

La Porta, Rafael, Florencio Lopez-de-Silanes, Andrei Shleifer, and Robert Vishny. 1998. Law and Finance. Journal of Political Economy 106:1113-1155. 
La Porta, Rafael, Florencio Lopez-de-Silanes, Andrei Shleifer, and Robert Vishny. 2000. Investor protection and corporate governance. Journal of Financial Economics 58:3-27.

MacNeil, Iain, and Xiao Li. 2006. "Comply or Explain": Market Discipline and Non-Compliance with the Combined Code. Corporate Governance: An International Review 14:486-496.

Michaels, Ralf. 2006. The Functional Method of Comparative Law, in: Mathias Reimann and Reinhard Zimmermann (eds.). The Oxford Handbook of Comparative Law 339-382, Oxford University Press.

Michaels, Ralf. 2009. Comparative Law by Numbers? Legal Origins Thesis, Doing Business Reports, and the Silence of Traditional Comparative Law. American Journal of Comparative Law 57:765-795.

Monks, Robert A.G., and Nell Minow. 2011. Corporate Governance. 5th ed., John Wiley \& Sons.

RiskMetrics Group. 2009. Study on Monitoring and Enforcement Practices in Corporate Governance in the Member States.

Roe, Mark J. 2005. Delaware's Politics. Harvard Law Review 118:2491-2543.

Schouten, Michael C. 2009. The Political Economy of Cross-Border Voting in Europe. Columbia Journal of European Law 16:1-36.

Siems, Mathias. 2005a. What does not work in comparing securities laws: A critique on La Porta et al.'s methodology. International Company and Commercial Law Review 2005:300-305.

Siems, Mathias. 2005b. Numerical comparative law: Do we need statistical evidence in law in order to reduce complexity. Cardozo Journal of International \& Comparative Law 13:521-540.

Siems, Mathias. 2007. Legal Origins: Reconciling Law \& Finance and Comparative Law. McGill Law Journal 52:55-81.

Spamann, Holger. 2006. On the Insignificance and/or Endogeneity of La Porta et al.'s 'Anti-Director Rights Index' under Consistent Coding. Harvard Law School John M. Olin Center Discussion Paper No. 7 (2006), ECGI - Law Working Paper No. 67/2006.

Spamann, Holger. 2009a. Contemporary Legal Transplants -- Legal Families and the Diffusion of (Corporate) Law. Brigham Young University Law Review 2009:1813-1877.

Spamann, Holger. 2009b. Large-Sample, Quantitative Research Designs for Comparative Law? American Journal of Comparative Law 57:797-810.

Spamann, Holger. 2009c. The 'Antidirector Rights Index' Revisited. Review of Financial Studies 23:467-486.

Tschentscher, Axel. 2007. Dialektische Rechtsvergleichung - Zur Methode der Komparistik im öffentlichen Recht. Juristenzeitung 2007:807-816.

Weil, Gotshal \& Manges. 2002. Comparative Study of Corporate Governance Codes Relevant to the European Union and Its Member States. Available at:

http://ec.europa.eu/internal_market/company/otherdocs/index_en.htm.

Zanetti, Alessandro, and Francesca Cuomo. 2008. Why Adopt Codes of Good Governance? A Comparison of Institutional and Efficiency Perspectives. Corporate Governance: An International Review 16:1-15. 
Zweigert, Konrad, and Hein Kötz. 1998. Introduction to Comparative Law. Translation Tony Weir. 3d ed., Oxford University Press. 
Table 1. Investor-friendliness of corporate governance codes

Table 1 reports the legal scores of the six elements of board structure for each corporate governance code, as well as the total score, which is treated as a proxy for the investor-friendliness of the code and used in the regression analysis as dependant variable. A higher value indicates a higher level of investor protection achieved by the relevant code provisions. The detailed legal definitions are contained in Appendix A and the coding protocol in Appendix B.

\begin{tabular}{|c|c|c|c|c|c|c|c|}
\hline \multirow[t]{2}{*}{ Country } & \multicolumn{6}{|c|}{ Individual measures of investor-friendliness } & \multirow{2}{*}{$\begin{array}{l}\text { Total } \\
\text { board } \\
\text { structure }\end{array}$} \\
\hline & $\begin{array}{c}\text { Executive/ } \\
\text { non-exec. }\end{array}$ & $\begin{array}{l}\text { No. ind. } \\
\text { directors }\end{array}$ & $\begin{array}{l}\text { Definition } \\
\text { of indep. }\end{array}$ & $\begin{array}{l}\text { Separation } \\
\text { chair/CEO }\end{array}$ & $\begin{array}{l}\text { Cooling- } \\
\text { off period }\end{array}$ & $\begin{array}{l}\text { Committee } \\
\text { structure }\end{array}$ & \\
\hline $\begin{array}{l}\text { Austria } \\
2009 \\
2002 \\
\end{array}$ & $\begin{array}{l}\mathrm{n} / \mathrm{a} \\
\mathrm{n} / \mathrm{a}\end{array}$ & $\begin{array}{l}1 \\
0.5 \\
\end{array}$ & $\begin{array}{l}0.3 \\
0.2\end{array}$ & $\begin{array}{l}\mathrm{n} / \mathrm{a} \\
\mathrm{n} / \mathrm{a}\end{array}$ & $\begin{array}{l}0.4 \\
0 \\
\end{array}$ & $\begin{array}{l}1 \\
0.5 \\
\end{array}$ & $\begin{array}{l}0.675 \\
0.3 \\
\end{array}$ \\
\hline $\begin{array}{l}\text { Belgium } \\
2009 \\
2004 \\
1998 \mathrm{E} \\
1998 \mathrm{C}\end{array}$ & $\begin{array}{l}1 \\
1 \\
0 \\
1\end{array}$ & $\begin{array}{l}0.5 \\
0.5 \\
0 \\
0 \\
\end{array}$ & $\begin{array}{l}1 \\
0.9 \\
0 \\
0.3\end{array}$ & $\begin{array}{l}1 \\
1 \\
0 \\
0\end{array}$ & $\begin{array}{l}0 \\
0 \\
0 \\
0\end{array}$ & $\begin{array}{l}1 \\
1 \\
0.08 \\
0.5\end{array}$ & $\begin{array}{l}0.75 \\
0.73 \\
0.01 \\
0.3 \\
\end{array}$ \\
\hline $\begin{array}{l}\text { Bulgaria } \\
2007\end{array}$ & 0 & 0 & 0.05 & 1 & 0 & 0.17 & 0.2 \\
\hline $\begin{array}{l}\text { Cyprus } \\
2002\end{array}$ & 0.5 & 1 & 0.3 & 0.75 & 0 & 0.67 & 0.54 \\
\hline $\begin{array}{l}\text { Denmark } \\
2010 \\
2003 \\
\end{array}$ & $\begin{array}{l}1 \\
1 \\
\end{array}$ & $\begin{array}{l}1 \\
1 \\
\end{array}$ & $\begin{array}{l}1 \\
0.4 \\
\end{array}$ & $\begin{array}{l}1 \\
0.5 \\
\end{array}$ & $\begin{array}{l}0 \\
0 \\
\end{array}$ & $\begin{array}{l}1 \\
0 \\
\end{array}$ & $\begin{array}{l}0.83 \\
0.48 \\
\end{array}$ \\
\hline $\begin{array}{l}\text { Finland } \\
2008 \\
2003 \\
\end{array}$ & $\begin{array}{l}1 \\
1 \\
\end{array}$ & $\begin{array}{l}1 \\
1 \\
\end{array}$ & $\begin{array}{l}0.8 \\
0.55 \\
\end{array}$ & & $\begin{array}{l}0 \\
0 \\
\end{array}$ & $\begin{array}{l}1 \\
0.67 \\
\end{array}$ & $\begin{array}{l}0.8 \\
0.7 \\
\end{array}$ \\
\hline $\begin{array}{l}\text { France } \\
2011 \\
2010 \\
2003 \\
1998 \\
1995 \\
\end{array}$ & $\begin{array}{l}0.5 \\
0.75 \\
0.75 \\
0.5 \\
0.5 \\
\end{array}$ & $\begin{array}{l}0.5 \\
0.75 \\
0.75 \\
0.5 \\
0.5 \\
\end{array}$ & $\begin{array}{l}0.65 \\
0.45 \\
0.45 \\
0.45 \\
0.4 \\
\end{array}$ & $\begin{array}{l}0.75 \\
0 \\
0 \\
0.5 \\
0 \\
\end{array}$ & $\begin{array}{l}0 \\
0 \\
0 \\
0 \\
0\end{array}$ & $\begin{array}{l}0.67 \\
1 \\
1 \\
0.58 \\
0.5 \\
\end{array}$ & $\begin{array}{l}0.51 \\
0.49 \\
0.49 \\
0.42 \\
0.32 \\
\end{array}$ \\
\hline $\begin{array}{l}\text { Germany } \\
2010 \\
2002 \\
2000 B \\
2000 \\
\end{array}$ & $\begin{array}{l}\mathrm{n} / \mathrm{a} \\
\mathrm{n} / \mathrm{a} \\
\mathrm{n} / \mathrm{a} \\
\mathrm{n} / \mathrm{a}\end{array}$ & $\begin{array}{l}0 \\
0 \\
0 \\
0 \\
\end{array}$ & $\begin{array}{l}0.3 \\
0.3 \\
0 \\
0.3 \\
\end{array}$ & $\begin{array}{l}\mathrm{n} / \mathrm{a} \\
\mathrm{n} / \mathrm{a} \\
\mathrm{n} / \mathrm{a} \\
\mathrm{n} / \mathrm{a}\end{array}$ & $\begin{array}{l}0.2 \\
0 \\
0 \\
0 \\
\end{array}$ & $\begin{array}{l}0.33 \\
0.17 \\
0.42 \\
0.25 \\
\end{array}$ & $\begin{array}{l}0.21 \\
0.12 \\
0.11 \\
0.14 \\
\end{array}$ \\
\hline $\begin{array}{l}\text { Greece } \\
2011 \\
2001 \\
1999 \\
\end{array}$ & $\begin{array}{l}0.75 \\
0 \\
1 \\
\end{array}$ & $\begin{array}{l}1 \\
0 \\
0\end{array}$ & $\begin{array}{l}0.8 \\
0.1 \\
0.3 \\
\end{array}$ & $\begin{array}{l}0.25 \\
0 \\
0.5 \\
\end{array}$ & $\begin{array}{l}0.175 \\
0 \\
0 \\
\end{array}$ & $\begin{array}{l}0.83 \\
0.25 \\
0.25 \\
\end{array}$ & $\begin{array}{l}0.63 \\
0.06 \\
0.34 \\
\end{array}$ \\
\hline $\begin{array}{l}\text { Hungary } \\
2004\end{array}$ & $\mathrm{n} / \mathrm{a}$ & 1 & 0.3 & $\mathrm{n} / \mathrm{a}$ & 0 & 1 & 0.58 \\
\hline $\begin{array}{l}\text { Italy } \\
2011 \\
1999 \\
\end{array}$ & $\begin{array}{l}0 \\
0\end{array}$ & $\begin{array}{l}0.5 \\
0\end{array}$ & $\begin{array}{l}0.4 \\
0.2\end{array}$ & $\begin{array}{l}0.75 \\
0\end{array}$ & $\begin{array}{l}0 \\
0\end{array}$ & $\begin{array}{l}0.75 \\
0.42 \\
\end{array}$ & $\begin{array}{l}0.4 \\
0.1\end{array}$ \\
\hline $\begin{array}{l}\text { Luxemb. } \\
2006\end{array}$ & 0 & 0 & 0.3 & 1 & 0 & 0.5 & 0.3 \\
\hline $\begin{array}{l}\text { Malta } \\
2001\end{array}$ & 0 & 1 & 0.3 & 0.75 & 0 & 0.67 & 0.45 \\
\hline
\end{tabular}




\begin{tabular}{|c|c|c|c|c|c|c|c|}
\hline $\begin{array}{l}\text { Netherl. } \\
2008 \\
2003 \\
\end{array}$ & $\begin{array}{l}\mathrm{n} / \mathrm{a} \\
\mathrm{n} / \mathrm{a}\end{array}$ & $\begin{array}{l}1 \\
1 \\
\end{array}$ & $\begin{array}{l}0.7 \\
0.7 \\
\end{array}$ & $\begin{array}{l}\mathrm{n} / \mathrm{a} \\
\mathrm{n} / \mathrm{a}\end{array}$ & $\begin{array}{l}1 \\
1 \\
\end{array}$ & $\begin{array}{l}1 \\
1 \\
\end{array}$ & $\begin{array}{l}0.925 \\
0.925 \\
\end{array}$ \\
\hline $\begin{array}{l}\text { Norway } \\
2010 \\
2004 \\
\end{array}$ & $\begin{array}{l}1 \\
1 \\
\end{array}$ & $\begin{array}{l}1 \\
0.5 \\
\end{array}$ & $\begin{array}{l}0.7 \\
0.7\end{array}$ & $\begin{array}{l}1 \\
1\end{array}$ & $\begin{array}{l}0 \\
0\end{array}$ & $\begin{array}{l}1 \\
0.67\end{array}$ & $\begin{array}{l}0.78 \\
0.645 \\
\end{array}$ \\
\hline $\begin{array}{l}\text { Poland } \\
2010 \\
2002 G \\
2002 C \\
\end{array}$ & $\begin{array}{l}\mathrm{n} / \mathrm{a} \\
\mathrm{n} / \mathrm{a} \\
\mathrm{n} / \mathrm{a}\end{array}$ & $\begin{array}{l}0.5 \\
0.5 \\
0.5 \\
\end{array}$ & $\begin{array}{l}1 \\
0.3 \\
0.3 \\
\end{array}$ & $\begin{array}{l}\mathrm{n} / \mathrm{a} \\
\mathrm{n} / \mathrm{a} \\
\mathrm{n} / \mathrm{a}\end{array}$ & $\begin{array}{l}0 \\
0 \\
0 \\
\end{array}$ & $\begin{array}{l}1 \\
0.08 \\
0.17 \\
\end{array}$ & $\begin{array}{l}0.625 \\
0.22 \\
0.24 \\
\end{array}$ \\
\hline $\begin{array}{l}\text { Portugal } \\
2010 \\
1999 \\
\end{array}$ & $\begin{array}{l}0.5 \\
0 \\
\end{array}$ & $\begin{array}{l}0.5 \\
0.125 \\
\end{array}$ & $\begin{array}{l}0.5 \\
0.1 \\
\end{array}$ & $\begin{array}{l}0 \\
0 \\
\end{array}$ & $\begin{array}{l}0 \\
0 \\
\end{array}$ & $\begin{array}{l}0.5 \\
0.25 \\
\end{array}$ & $\begin{array}{l}0.33 \\
0.08 \\
\end{array}$ \\
\hline $\begin{array}{l}\text { Slovakia } \\
2008\end{array}$ & $\mathrm{n} / \mathrm{a}$ & 0.5 & 0.4 & $\mathrm{n} / \mathrm{a}$ & 0.5 & 0.75 & 0.54 \\
\hline $\begin{array}{l}\text { Slovenia } \\
2009 \\
2004 \\
\end{array}$ & $\begin{array}{l}\mathrm{n} / \mathrm{a} \\
\mathrm{n} / \mathrm{a}\end{array}$ & $\begin{array}{l}0.5 \\
1 \\
\end{array}$ & $\begin{array}{l}1 \\
0.3 \\
\end{array}$ & $\begin{array}{l}\mathrm{n} / \mathrm{a} \\
\mathrm{n} / \mathrm{a}\end{array}$ & $\begin{array}{l}0.4 \\
0 \\
\end{array}$ & $\begin{array}{l}0.67 \\
0.33 \\
\end{array}$ & $\begin{array}{l}0.64 \\
0.41\end{array}$ \\
\hline $\begin{array}{l}\text { Spain } \\
2006 \\
2004 \\
2003\end{array}$ & $\begin{array}{l}1 \\
0.5 \\
1\end{array}$ & $\begin{array}{l}0.5 \\
0.75 \\
0.5\end{array}$ & $\begin{array}{l}0.9 \\
1 \\
0.3\end{array}$ & $\begin{array}{l}0.25 \\
1 \\
0\end{array}$ & $\begin{array}{l}0 \\
0 \\
0\end{array}$ & $\begin{array}{l}0.67 \\
0.83 \\
0.5\end{array}$ & $\begin{array}{l}0.55 \\
0.68 \\
0.38\end{array}$ \\
\hline $\begin{array}{l}\text { Sweden } \\
2010 \\
2001 \\
\end{array}$ & $\begin{array}{l}1 \\
1\end{array}$ & $\begin{array}{l}1 \\
1\end{array}$ & $\begin{array}{l}0.8 \\
0 \\
\end{array}$ & $\begin{array}{l}1 \\
1 \\
\end{array}$ & $\begin{array}{l}0 \\
0.5\end{array}$ & $\begin{array}{l}0.67 \\
0.5 \\
\end{array}$ & $\begin{array}{l}0.745 \\
0.67 \\
\end{array}$ \\
\hline $\begin{array}{l}\text { Switzerl. } \\
2007 \\
2002\end{array}$ & $\begin{array}{l}1 \\
1\end{array}$ & $\begin{array}{l}0 \\
0\end{array}$ & $\begin{array}{l}0.3 \\
0.3\end{array}$ & $\begin{array}{l}0 \\
0\end{array}$ & $\begin{array}{l}0 \\
0\end{array}$ & $\begin{array}{l}0.75 \\
0.75\end{array}$ & $\begin{array}{l}0.34 \\
0.34\end{array}$ \\
\hline $\begin{array}{l}\mathrm{UK}^{83} \\
2010 \\
2003 \\
1998 \\
1992\end{array}$ & $\begin{array}{l}0.75 \\
0.75 \\
0.5 \\
0\end{array}$ & $\begin{array}{l}1 \\
1 \\
1 \\
1\end{array}$ & $\begin{array}{l}0.675 \\
0.675 \\
0.3 \\
0.3\end{array}$ & $\begin{array}{l}1 \\
1 \\
0.75 \\
0\end{array}$ & $\begin{array}{l}1 \\
1 \\
0 \\
0\end{array}$ & $\begin{array}{l}1 \\
1 \\
0.83 \\
0.33\end{array}$ & $\begin{array}{l}0.9 \\
0.9 \\
0.56 \\
0.27\end{array}$ \\
\hline
\end{tabular}

${ }^{83}$ For purposes of developing a benchmark to be used as explanatory variable in the regressions below in Table 7, I take the value for board structure of the UK codes of 1992-2003. Beginning in 2006, after adoption of Commission Recommendation 2005/162/EC, I combine the Recommendation and the UK code and quantify the elements of board structure according to the more investor-friendly rule. The score of the combined UK Corporate Governance Code 2010 and the Commission Recommendation is as follows: executive/non-executive 0.75 (UK code); number of independent directors 1 (UK code); definition of independence 1 (Commission Recommendation); separation chairman and CEO 1 (UK code); cooling-off period 1 (UK code); committee structure 1 (UK code); total board structure 0.96 . 
Table 2. Composition of corporate governance committees

The Table reports the composition of corporate governance committees in the sample jurisdictions by affiliation of the committee member as issuer representative, investor representative, or neutral (technocrat, academic, government body, stock exchange etc.). Authors1 is the sum of 1 times the number of investor representatives and 0.5 times the number of neutral members divided by the total number of committee members. Authors2 equals the ratio of investor representatives to the sum of investor and issuer representatives, i.e. not counting the neutral members. Authors3 equals 1 if a majority of committee members are investor representatives, 0.5 if the same number of issuer and investor representatives are on the committee, and 0 otherwise, again excluding the neutral members.

\begin{tabular}{|c|c|c|c|c|c|c|c|}
\hline Country & Committee & Issuer & Inv. & Neutral & $\begin{array}{l}\text { Authors } \\
1\end{array}$ & $\begin{array}{l}\text { Authors } \\
2\end{array}$ & $\begin{array}{l}\text { Authors } \\
3\end{array}$ \\
\hline $\begin{array}{l}\text { Austria } \\
2009 \\
2002\end{array}$ & $\begin{array}{l}\text { Working Group Corp. Gov. } \\
\text { Working Group Corp. Gov. }\end{array}$ & $\begin{array}{l}8 \\
8\end{array}$ & $\begin{array}{l}5 \\
5\end{array}$ & $\begin{array}{l}12 \\
12\end{array}$ & $\begin{array}{l}0.44 \\
0.44\end{array}$ & $\begin{array}{l}0.38 \\
0.38\end{array}$ & $\begin{array}{l}0 \\
0\end{array}$ \\
\hline $\begin{array}{l}\text { Belgium } \\
2009 \\
2004 \\
1998 \mathrm{E} \\
1998 \mathrm{C}\end{array}$ & $\begin{array}{l}\text { Belg. Corp. Gov. Committee } \\
\text { Belg. Corp. Gov. Committee } \\
\text { Federation Belg. Enterprises } \\
\text { Corp. Gov. Committee } 84\end{array}$ & $\begin{array}{l}11 \\
11 \\
9 \\
5\end{array}$ & $\begin{array}{l}5 \\
1 \\
1 \\
3\end{array}$ & $\begin{array}{l}7 \\
3 \\
0 \\
6\end{array}$ & $\begin{array}{l}0.37 \\
0.17 \\
0.1 \\
0.43\end{array}$ & $\begin{array}{l}0.3 \\
0.08 \\
0.1 \\
0.38\end{array}$ & $\begin{array}{l}0 \\
0 \\
0 \\
0\end{array}$ \\
\hline $\begin{array}{l}\text { Bulgaria } \\
2007\end{array}$ & Bulgarian Stock Exchange & 5 & 3 & 9 & 0.44 & 0.38 & 0 \\
\hline $\begin{array}{l}\text { Cyprus } \\
2002\end{array}$ & Cyprus Stock Exchange & 0 & 0 & 1 & 0.5 & 0.5 & 0.5 \\
\hline $\begin{array}{l}\text { Denmark } \\
2010 \\
2003 \\
\end{array}$ & $\begin{array}{l}\text { Copenhagen Stock Exch. }{ }^{85} \\
\text { Copenhagen Stock Exch. }\end{array}$ & $\begin{array}{l}4 \\
4 \\
\end{array}$ & $\begin{array}{l}1 \\
1\end{array}$ & $\begin{array}{l}3 \\
2 \\
\end{array}$ & $\begin{array}{l}0.31 \\
0.29 \\
\end{array}$ & $\begin{array}{l}0.2 \\
0.2 \\
\end{array}$ & $\begin{array}{l}0 \\
0 \\
\end{array}$ \\
\hline $\begin{array}{l}\text { Finland } \\
2008 \\
2003 \\
\end{array}$ & $\begin{array}{l}\text { Securities Market Assoc. } \\
\text { Various organisations }{ }^{86} \\
\end{array}$ & $\begin{array}{l}6 \\
6 \\
\end{array}$ & $\begin{array}{l}1 \\
0\end{array}$ & $\begin{array}{l}1 \\
3\end{array}$ & $\begin{array}{l}0.19 \\
0.17\end{array}$ & $\begin{array}{l}0.14 \\
0\end{array}$ & $\begin{array}{l}0 \\
0\end{array}$ \\
\hline $\begin{array}{l}\text { France } \\
2011 \\
2010 \\
2003 \\
1998 \\
1995 \\
\end{array}$ & $\begin{array}{l}\text { AFG }^{87} \\
\text { AFEP/MEDEF } 88 \\
\text { AFEP/MEDEF } 89 \\
\text { AFG } \\
\text { Vienot I (AFEP) }\end{array}$ & $\begin{array}{l}13 \\
0 \\
13 \\
\end{array}$ & $\begin{array}{l}0 \\
13 \\
1 \\
\end{array}$ & $\begin{array}{l}1 \\
0 \\
0\end{array}$ & $\begin{array}{l}1 \\
0.04 \\
0.04 \\
1 \\
0.07\end{array}$ & $\begin{array}{l}1 \\
0 \\
0 \\
1 \\
0.07 \\
\end{array}$ & $\begin{array}{l}1 \\
0 \\
0 \\
1 \\
0\end{array}$ \\
\hline $\begin{array}{l}\text { Germany } \\
2010 \\
2002 \\
2000 B \\
2000\end{array}$ & $\begin{array}{l}\text { Government Commission } \\
\text { Government Commission } \\
\text { Berliner Initiativkreis } \\
\text { Panel on Corp. Governance }\end{array}$ & $\begin{array}{l}3 \\
6 \\
5 \\
4\end{array}$ & $\begin{array}{l}2 \\
2 \\
0 \\
2\end{array}$ & $\begin{array}{l}8 \\
5 \\
5 \\
4\end{array}$ & $\begin{array}{l}0.46 \\
0.35 \\
0.25 \\
0.4\end{array}$ & $\begin{array}{l}0.4 \\
0.25 \\
0 \\
0.33\end{array}$ & $\begin{array}{l}0 \\
0 \\
0 \\
0\end{array}$ \\
\hline $\begin{array}{l}\text { Greece } \\
2011 \\
2001 \\
1999\end{array}$ & $\begin{array}{l}\mathrm{SEV}^{90} \\
\text { Federation Greek Industries } \\
\text { Capital Market Commission }\end{array}$ & $\begin{array}{l}1 \\
1 \\
5\end{array}$ & $\begin{array}{l}0 \\
0 \\
2 \\
\end{array}$ & $\begin{array}{l}0 \\
0 \\
10 \\
\end{array}$ & $\begin{array}{l}0 \\
0 \\
0.41\end{array}$ & $\begin{array}{l}0 \\
0 \\
0.29\end{array}$ & $\begin{array}{l}0 \\
0 \\
0 \\
\end{array}$ \\
\hline
\end{tabular}

${ }^{84}$ Cardon Report, prepared by the Belgian Corporate Governance Committee - Commission Bancaire et Financiere.

${ }^{85}$ The Stock Exchange has appointed a Corporate Governance Committee (Komité for god Selskabsledelse), which drafts the code.

${ }^{86}$ HEX Plc; Central Chamber of Commerce of Finland; Confederation of Finnish Industry and Employers.

${ }^{87}$ Classification of committee composition is based on the AFG code of 1998.

${ }^{88}$ Classification of committee composition is based on the AFEP/MEDEF code of 2003.

${ }^{89}$ The Code is based on 'Promoting Better Corporate Governance In Listed Companies', Report of a working group chaired by Daniel Bouton. Our classification is based on the composition of this working group.

${ }^{90}$ Hellenic Federation of Enterprises. 


\begin{tabular}{|c|c|c|c|c|c|c|c|}
\hline $\begin{array}{l}\text { Hungary } \\
2004\end{array}$ & Budapest Stock Exchange & 1 & 1 & 14 & 0.5 & 0.5 & 0.5 \\
\hline $\begin{array}{l}\text { Italy } \\
2011 \\
1999 \\
\end{array}$ & $\begin{array}{l}\text { Borsa Italiana } \\
\text { Borsa Italiana (Preda Code) }\end{array}$ & $\begin{array}{l}19 \\
15 \\
\end{array}$ & $\begin{array}{l}3 \\
3 \\
\end{array}$ & $\begin{array}{l}5 \\
8 \\
\end{array}$ & $\begin{array}{l}0.2 \\
0.27 \\
\end{array}$ & $\begin{array}{l}0.14 \\
0.17\end{array}$ & $\begin{array}{l}0 \\
0\end{array}$ \\
\hline $\begin{array}{l}\text { Luxemb. } \\
2006\end{array}$ & Luxemb. Stock Exchange & 9 & 5 & 2 & 0.375 & 0.36 & 0 \\
\hline $\begin{array}{l}\text { Malta } \\
2001\end{array}$ & Malta Stock Exchange & 1 & 2 & 4 & 0.57 & 0.67 & 1 \\
\hline $\begin{array}{l}\text { Netherl. } \\
2008 \\
2003\end{array}$ & $\begin{array}{l}\text { Monitoring Committee } \\
\text { Tabaksblat Committee }\end{array}$ & $\begin{array}{l}2 \\
4\end{array}$ & $\begin{array}{l}2 \\
3 \\
\end{array}$ & $\begin{array}{l}4 \\
6\end{array}$ & $\begin{array}{l}0.50 \\
0.46\end{array}$ & $\begin{array}{l}0.5 \\
0.43\end{array}$ & $\begin{array}{l}0.5 \\
0\end{array}$ \\
\hline $\begin{array}{l}\text { Norway } \\
2010 \\
2004\end{array}$ & $\begin{array}{l}\text { Corp. Governance Board } \\
\text { Various organisations }\end{array}$ & $\begin{array}{l}2 \\
2\end{array}$ & $\begin{array}{l}5 \\
5\end{array}$ & $\begin{array}{l}2 \\
2\end{array}$ & $\begin{array}{l}0.67 \\
0.67\end{array}$ & $\begin{array}{l}0.71 \\
0.71\end{array}$ & $\begin{array}{l}1 \\
1\end{array}$ \\
\hline $\begin{array}{l}\text { Poland } \\
2010 \\
2002 \mathrm{G} \\
2002 \mathrm{C} \\
\end{array}$ & $\begin{array}{l}\text { Warsaw Stock Exchange } \\
\text { Gdańsk Institute } \\
\text { Corp. Governance Forum }\end{array}$ & $\begin{array}{l}0 \\
0 \\
0\end{array}$ & $\begin{array}{l}0 \\
5 \\
0 \\
\end{array}$ & $\begin{array}{l}1 \\
2 \\
6\end{array}$ & $\begin{array}{l}0.5 \\
0.86 \\
0.5 \\
\end{array}$ & $\begin{array}{l}0.5 \\
1 \\
0.5\end{array}$ & $\begin{array}{l}0.5 \\
1 \\
0.5\end{array}$ \\
\hline $\begin{array}{l}\text { Portugal } \\
2010 \\
1999\end{array}$ & $\begin{array}{l}\text { CMVM }^{91} \\
\text { CMVM }^{92}\end{array}$ & $\begin{array}{l}0 \\
0\end{array}$ & $\begin{array}{l}0 \\
0\end{array}$ & $\begin{array}{l}1 \\
1\end{array}$ & $\begin{array}{l}0.5 \\
0.5\end{array}$ & $\begin{array}{l}0.5 \\
0.5\end{array}$ & $\begin{array}{l}0.5 \\
0.5\end{array}$ \\
\hline $\begin{array}{l}\text { Slovakia } \\
2008\end{array}$ & Corp. Gov. Association ${ }^{93}$ & 1 & 1 & 3 & 0.5 & 0.5 & 0.5 \\
\hline $\begin{array}{l}\text { Slovenia } \\
2009 \\
2004\end{array}$ & $\begin{array}{l}\text { Various organisations }^{94} \\
\text { Various organisations }^{95}\end{array}$ & $\begin{array}{l}2 \\
2\end{array}$ & $\begin{array}{l}0 \\
0\end{array}$ & $\begin{array}{l}1 \\
1\end{array}$ & $\begin{array}{l}0.17 \\
0.17\end{array}$ & $\begin{array}{l}0 \\
0\end{array}$ & $\begin{array}{l}0 \\
0\end{array}$ \\
\hline $\begin{array}{l}\text { Spain } \\
2006 \\
2004 \\
2003\end{array}$ & $\begin{array}{l}\text { CNMV }^{96} \\
\text { IC-A }^{97} \\
\text { Aldama Commission }^{98}\end{array}$ & $\begin{array}{l}3 \\
1 \\
3\end{array}$ & $\begin{array}{l}0 \\
0 \\
0\end{array}$ & $\begin{array}{l}11 \\
0 \\
12 \\
\end{array}$ & $\begin{array}{l}0.39 \\
0 \\
0.4\end{array}$ & $\begin{array}{l}0 \\
0 \\
0 \\
\end{array}$ & $\begin{array}{l}0 \\
0 \\
0\end{array}$ \\
\hline $\begin{array}{l}\text { Sweden } \\
2010 \\
2001 \\
\end{array}$ & $\begin{array}{l}\text { Corp. Governance Board } \\
\text { Shareholders' Association }\end{array}$ & $\begin{array}{l}6 \\
0 \\
\end{array}$ & $\begin{array}{l}3 \\
1\end{array}$ & $\begin{array}{l}5 \\
0 \\
\end{array}$ & $\begin{array}{l}0.39 \\
1 \\
\end{array}$ & $\begin{array}{l}0.33 \\
1 \\
\end{array}$ & $\begin{array}{l}0 \\
1\end{array}$ \\
\hline $\begin{array}{l}\text { Switzerl. } \\
2007 \\
2002\end{array}$ & $\begin{array}{l}\text { Economiesuisse } \\
\text { Economiesuisse }\end{array}$ & $\begin{array}{l}6 \\
4\end{array}$ & $\begin{array}{l}0 \\
0\end{array}$ & $\begin{array}{l}3 \\
2\end{array}$ & $\begin{array}{l}0.17 \\
0.17\end{array}$ & $\begin{array}{l}0 \\
0\end{array}$ & $\begin{array}{l}0 \\
0\end{array}$ \\
\hline $\begin{array}{l}\mathrm{UK} \\
2010 \\
2003^{99} \\
1998 \\
1992 \\
\end{array}$ & $\begin{array}{l}\text { FRC } \\
\text { FRC/Higgs/Smith } \\
\text { Hampel } \\
\text { Cadbury }\end{array}$ & $\begin{array}{l}2 \\
3 \\
6 \\
3 \\
\end{array}$ & $\begin{array}{l}3 \\
1 \\
2 \\
1\end{array}$ & $\begin{array}{l}3 \\
4 \\
3 \\
8 \\
\end{array}$ & $\begin{array}{l}0.56 \\
0.375 \\
0.32 \\
0.42 \\
\end{array}$ & $\begin{array}{l}0.6 \\
0.25 \\
0.25 \\
0.25 \\
\end{array}$ & $\begin{array}{l}1 \\
0 \\
0 \\
0\end{array}$ \\
\hline
\end{tabular}

${ }^{91}$ Comissão do Mercado de Valores Mobiliários. The code was drafted exclusively by employees of CMVM without outside involvement. The committee is therefore classified as 'neutral'.

92 See $\mathrm{n} 91$ above.

${ }^{93}$ Stredoeurópska asociácia správy a riadenia spoločností (Central European Corporate Governance Association).

${ }^{94}$ Ljubljana Stock Exchange; Association of Supervisory Board Members of Slovenia; Managers' Association of Slovenia.

${ }^{95}$ Ljubljana Stock Exchange; Association of Supervisory Board Members of Slovenia; Managers' Association of Slovenia.

${ }^{96}$ Comisión Nacional del Mercado de Valores.

${ }^{97}$ Instituto de Consejeros-Administradores (Institute of Directors-Administrators).

${ }^{98}$ Special Commission to foster transparency and security in the markets and in listed companies.

99 The Combined Code of 2003 was published by the Financial Reporting Council (FRC) and derived from the Higgs Report (2003) and a review of audit committees by a group led by Sir Robert Smith (Smith Report, 2003). Our classification of the composition of the corporate governance committee is based on both the background of Sir Derek Higgs and the composition of the Smith group. 


\section{Table 3. Country dummies}

The Table reports the allocation of countries to legal families and the coding of the legal and political dummies. Unitary board is 1 if the country's company law provides for a unitary, one-tier board model; Employee representation is 1 if the country's company law requires at least one employee representative at board level. Both variables represent the legal situation as of the time of adoption of the respective corporate governance code. Political orientation of the governing party is 1 if the party in power in the year before publication of the code was social democratic.

\begin{tabular}{|c|c|c|c|c|c|}
\hline \multirow{2}{*}{$\begin{array}{l}\text { Country } \\
\text { Austria }\end{array}$} & \multirow{3}{*}{$\begin{array}{l}\text { Legal family } \\
\text { German }\end{array}$} & \multirow{3}{*}{$\begin{array}{c}\text { Unitary board } \\
0\end{array}$} & \multirow{2}{*}{$\begin{array}{l}\text { Employee } \\
\text { representation }\end{array}$} & \multicolumn{2}{|c|}{$\begin{array}{l}\text { Political orientation of the } \\
\text { governing party }\end{array}$} \\
\hline & & & & 2009 & 1 \\
\hline & & & & 2002 & 0 \\
\hline \multirow[t]{3}{*}{ Belgium } & French & 1 & 0 & 2009 & 0 \\
\hline & & & & 2004 & 0 \\
\hline & & & & 1998 & 0 \\
\hline Bulgaria & French & 1 & 0 & 2007 & 1 \\
\hline Cyprus & Common law & 1 & 0 & 2002 & 0 \\
\hline \multirow[t]{2}{*}{ Denmark } & Scandinavian & 1 & 1 & 2010 & 0 \\
\hline & & & & 2003 & 0 \\
\hline \multirow[t]{2}{*}{ Finland } & Scandinavian & 1 & 1 & 2008 & 0 \\
\hline & & & & 2003 & 1 \\
\hline \multirow[t]{5}{*}{ France } & French & 1 & 0 & 2011 & 0 \\
\hline & & & & 2010 & 0 \\
\hline & & & & 2003 & 0 \\
\hline & & & & 1998 & 0 \\
\hline & & & & 1995 & 0 \\
\hline \multirow[t]{3}{*}{ Germany } & German & 0 & 1 & 2010 & 0 \\
\hline & & & & 2002 & 1 \\
\hline & & & & 2000 & 1 \\
\hline \multirow[t]{3}{*}{ Greece } & German & 1 & 0 & 2011 & 1 \\
\hline & & & & 2001 & 1 \\
\hline & & & & 1999 & 1 \\
\hline Hungary & German & 0 & 1 & 2004 & 1 \\
\hline \multirow{2}{*}{ Italy } & French & 1 & 0 & 2011 & 0 \\
\hline & & & & 1999 & 1 \\
\hline Luxembourg & French & 1 & 1 & 2006 & 0 \\
\hline Malta & Common law & 1 & 0 & 2001 & 0 \\
\hline \multirow[t]{2}{*}{ Netherlands } & French & 0 & 0 & 2008 & 1 \\
\hline & & & & 2003 & 0 \\
\hline \multirow[t]{2}{*}{ Norway } & Scandinavian & 1 & 1 & 2010 & 1 \\
\hline & & & & 2004 & 0 \\
\hline \multirow[t]{2}{*}{ Poland } & German & 0 & 0 & 2010 & 0 \\
\hline & & & & 2002 & 1 \\
\hline \multirow[t]{2}{*}{ Portugal } & German & 1 & 0 & 2010 & 1 \\
\hline & & & & 1999 & 1 \\
\hline Slovakia & German & 0 & 1 & 2008 & 1 \\
\hline \multirow[t]{2}{*}{ Slovenia } & German & 0 & 1 & 2009 & 1 \\
\hline & & & & 2004 & 0 \\
\hline \multirow[t]{3}{*}{ Spain } & French & 1 & 0 & 2006 & 1 \\
\hline & & & & 2004 & 0 \\
\hline & & & & 2003 & 0 \\
\hline \multirow[t]{2}{*}{ Sweden } & Scandinavian & 1 & 1 & 2010 & 0 \\
\hline & & & & 2001 & 1 \\
\hline \multirow[t]{2}{*}{ Switzerland } & German & 1 & 0 & 2007 & 0 \\
\hline & & & & 2002 & 0 \\
\hline \multirow[t]{4}{*}{ UK } & Common law & 1 & 0 & 2010 & 1 \\
\hline & & & & 2003 & 1 \\
\hline & & & & 1998 & 1 \\
\hline & & & & 1992 & 0 \\
\hline
\end{tabular}


Table 4. Summary statistics

The table reports summary statistics for the variables in the dataset with the exception of the legal origins dummies. Board structure is the mean of the six legal elements reported in Table 1 and is used as a proxy for investor-friendliness of corporate governance codes. The variable is continuous on a scale from 0 to 1 . Authors1-3 are based on the three methods of calculating the investor/issuer orientation of corporate governance committees, also measured on a scale from 0 to 1 . A higher score indicates a greater proportion of investor-affiliated persons on the committee. Country-level scores of the author variables are reported in Table 2. Sophistication I measures the international dissemination of corporate governance initiatives ("sophistication" of the corporate governance debate) by using the UK corporate governance code in force at the relevant time as a benchmark. Sophistication II measures the dissemination of corporate governance initiatives as the time lag between the publication of the first European initiative, the Cadbury Report of 1992, and the adoption of the respective code. Market cap/GDP is the ratio of market capitalization and GDP, measured as a five-year average counting back from the adoption of the code in order to limit fluctuations. FDI is the ratio of foreign direct investment net inflows and GDP, and Portfolio equity the ratio of portfolio equity net inflows and GDP. These two variables are also measured as a five-year average. Government effectiveness measures perceptions of the quality of public services and the civil service on a scale from 0 to 5 (transcribed from the original World Bank data on a scale from -2.5 to 2.5). Regulatory quality measures perceptions of the government's ability to promote private sector development on the same scale as Government effectiveness. The three dummy variables Political (political orientation of the governing party), Unitary board (one-tier vs. two-tier board model), and Employee rep. (employee representative at board level) are described in Table 3.

\begin{tabular}{lllllll}
\hline & Obs. & Mean & Median & Min. & Max. & Std. Dev. \\
\hline Board structure & 52 & 0.48 & 0.49 & 0.01 & 0.93 & 0.25 \\
Authors1 & 52 & 0.38 & 0.39 & 0 & 1 & 0.24 \\
Authors2 & 52 & 0.32 & 0.3 & 0 & 1 & 0.29 \\
Authors3 & 52 & 0.23 & 0 & 0 & 1 & 0.38 \\
Sophistication I & 48100 & 0.74 & 0.9 & 0.27 & 0.96 & 0.23 \\
Sophistication II & 52 & 12.27 & 11.5 & 0 & 17 & 4.58 \\
Market cap/GDP & 52 & 0.72 & 0.54 & 0.07 & 2.53 & 0.53 \\
FDI & 52 & 0.06 & 0.04 & 0 & 0.54 & 0.09 \\
Portfolio equity & 52 & 0.09 & 0.01 & -0.01 & 4.02 & 0.56 \\
Gov. effectiveness & 52 & 3.98 & 4.20 & 2.48 & 4.79 & 0.56 \\
Regulatory quality & 52 & 3.79 & 3.79 & 3.05 & 4.54 & 0.39 \\
Political & 52 & 0.46 & 0 & 0 & 1 & 0.503 \\
Unitary board & 52 & 0.71 & 1 & 0 & 1 & 0.46 \\
Employee rep. & 52 & 0.37 & 0 & 0 & 1 & 0.49 \\
\hline
\end{tabular}

\footnotetext{
100 Because the four UK codes are used as a benchmark.
} 
Table 5. Comparison of board structure and composition of corporate governance committees

This table compares board structure and the composition of corporate governance committees for selected observations. The selection focuses on countries with several codes in the sample and/or different code issuers.

\begin{tabular}{llllll}
\hline Country & Code issuer & $\begin{array}{l}\text { Board } \\
\text { structure }\end{array}$ & Authors1 & Authors2 & Authors3 \\
\hline Belgium 2009 & Corp. Gov. Committee & 0.75 & 0.37 & 0.3 & 0 \\
Belgium 2004 & Corp. Gov. Committee & 0.73 & 0.17 & 0.08 & 0 \\
Belgium 1998 & Federation Enterprises & 0.01 & 0.1 & 0.1 & 0 \\
Belgium 1998 & Corp. Gov. Committee & 0.3 & 0.43 & 0.38 & 0 \\
France 2011 & AFG & 0.51 & 1 & 1 & 1 \\
France 2010 & AFEP/MEDEF & 0.49 & 0.04 & 0 & 0 \\
France 2003 & AFEP/MEDEF & 0.49 & 0.04 & 0 & 0 \\
France 1998 & AFG & 0.42 & 1 & 1 & 1 \\
France 1995 & Vienot I (AFEP) & 0.32 & 0.07 & 0.07 & 0 \\
Greece 2011 & Industry & 0.63 & 0 & 0 & 0 \\
Greece 2001 & Industry & 0.06 & 0 & 0 & 0 \\
Greece 1999 & Capital Market Comm. & 0.34 & 0.41 & 0.29 & 0 \\
Italy 2011 & Borsa Italiana & 0.4 & 0.2 & 0.14 & 0 \\
Italy 1999 & Borsa Italiana (Preda) & 0.1 & 0.27 & 0.17 & 0 \\
Poland 2010 & Stock Exchange & 0.625 & 0.5 & 0.5 & 0.5 \\
Poland 2002 & Gdańsk Institute & 0.22 & 0.86 & 1 & 1 \\
Poland 2002 & Corp. Gov. Forum & 0.24 & 0.5 & 0.5 & 0.5 \\
Sweden 2010 & Corp. Gov. Board & 0.745 & 0.39 & 0.33 & 0 \\
Sweden 2001 & Shareholders' Assoc. & 0.67 & 1 & 1 & 1 \\
& & & & & \\
\hline
\end{tabular}


Table 6. Analysis of investor-friendliness

Panel A. Elements of board structure regulation

The table reports summary statistics for the six elements of the board structure variable as described in Appendix A.

\begin{tabular}{lllllll}
\hline & Obs. & Mean & Median & Max. & Min. & Std. Dev. \\
\hline $\begin{array}{l}\text { Executive/non- } \\
\text { executive }\end{array}$ & 37 & 0.628 & 0.75 & 1 & 0 & 0.407 \\
$\begin{array}{l}\text { Number of in- } \\
\text { dependent directors }\end{array}$ & 52 & 0.565 & 0.5 & 1 & 0 & 0.399 \\
$\begin{array}{l}\text { Definition of } \\
\text { independence }\end{array}$ & 52 & 0.463 & 0.35 & 1 & 0 & 0.288 \\
$\begin{array}{l}\text { Separation of } \\
\text { chairman/CEO }\end{array}$ & 37 & 0.534 & 0.75 & 1 & 0 & 0.446 \\
$\begin{array}{l}\text { Cooling-off period } \\
\text { for CEO }\end{array}$ & 52 & 0.119 & 0 & 1 & 0 & 0.286 \\
$\begin{array}{l}\text { Committee } \\
\text { structure }\end{array}$ & 52 & 0.624 & 0.67 & 1 & 0 & 0.307 \\
$\begin{array}{l}\text { Total board } \\
\text { structure }\end{array}$ & 52 & 0.475 & 0.488 & 0.925 & 0.013 & 0.251 \\
\hline
\end{tabular}

Panel B. Pairwise correlation of the elements of board structure regulation (significance at the 10, 5 and 1 percent levels are indicated by $*, * *$ and $* * *$, respectively)

\begin{tabular}{l|cccccc} 
& Exec. & $\begin{array}{l}\text { Number } \\
\text { ind. dir. }\end{array}$ & $\begin{array}{l}\text { Def. ind. } \\
\text { dir. }\end{array}$ & Sep. & $\begin{array}{l}\text { Cooling- } \\
\text { off }\end{array}$ & Comm. \\
\hline $\begin{array}{l}\text { Executive/non- } \\
\text { executive }\end{array}$ & 1 & & & & \\
$\begin{array}{l}\text { Number of in- } \\
\text { dependent directors }\end{array}$ & $0.308^{*}$ & 1 & & & \\
$\begin{array}{l}\text { Definition of } \\
\text { independence }\end{array}$ & $0.528^{* * *}$ & $0.418^{* * *}$ & 1 & & \\
$\begin{array}{l}\text { Separation of } \\
\text { chairman/CEO }\end{array}$ & 0.215 & $0.459^{* * *}$ & $0.47^{* * *}$ & 1 & \\
$\begin{array}{l}\text { Cooling-off period } \\
\text { for CEO }\end{array}$ & 0.128 & $0.351^{* *}$ & 0.194 & $0.289^{*}$ & 1 \\
$\begin{array}{l}\text { Committee } \\
\text { structure }\end{array}$ & $0.454^{* *}$ & $0.535^{* * *}$ & $0.645^{* * *}$ & $0.392^{* *}$ & $0.37^{* * *}$ & 1
\end{tabular}


Panel C. Investor-friendliness by legal tradition

\begin{tabular}{|c|c|c|c|c|c|c|c|c|c|c|c|c|}
\hline \multirow[t]{2}{*}{ Observations } & \multicolumn{3}{|c|}{$\begin{array}{c}\text { English }^{101} \\
6\end{array}$} & \multicolumn{3}{|c|}{$\begin{array}{c}\text { French }^{102} \\
18^{105} \\
\end{array}$} & \multicolumn{3}{|c|}{$\begin{array}{l}\text { German }^{103} \\
20^{106}\end{array}$} & \multicolumn{3}{|c|}{$\begin{array}{l}\text { Scandinavian } \\
8 \\
8\end{array}$} \\
\hline & Mean & Median & Std. Dev. & Mean & Median & Std. Dev. & Mean & Median & Std. Dev. & Mean & Median & Std. Dev. \\
\hline $\begin{array}{l}\text { Executive/non- } \\
\text { executive }\end{array}$ & 0.42 & 0.5 & 0.34 & 0.53 & 0.5 & 0.42 & 0.61 & 0.75 & 0.45 & 1 & 1 & 0 \\
\hline $\begin{array}{l}\text { Number of in- } \\
\text { dependent directors }\end{array}$ & 1 & 1 & 0 & 0.46 & 0.5 & 0.33 & 0.38 & 0.5 & 0.39 & 0.94 & 1 & 0.18 \\
\hline $\begin{array}{l}\text { Definition of } \\
\text { independence }\end{array}$ & 0.43 & 0.3 & 0.19 & 0.51 & 0.45 & 0.31 & 0.37 & 0.3 & 0.27 & 0.62 & 0.7 & 0.31 \\
\hline $\begin{array}{l}\text { Separation of } \\
\text { chairman/CEO }\end{array}$ & 0.71 & 0.75 & 0.37 & 0.45 & 0.38 & 0.46 & 0.11 & 0 & 0.2 & 0.94 & 1 & 0.18 \\
\hline $\begin{array}{l}\text { Cooling-off period } \\
\text { for CEO }\end{array}$ & 0.33 & 0 & 0.52 & 0.11 & 0 & 0.32 & 0.08 & 0 & 0.16 & 0.06 & 0 & 0.18 \\
\hline $\begin{array}{l}\text { Committee } \\
\text { structure }\end{array}$ & 0.75 & 0.75 & 0.25 & 0.68 & 0.67 & 0.29 & 0.51 & 0.46 & 0.31 & 0.69 & 0.67 & 0.34 \\
\hline $\begin{array}{l}\text { Total board } \\
\text { structure }\end{array}$ & 0.61 & 0.55 & 0.25 & 0.47 & 0.46 & 0.26 & 0.35 & 0.34 & 0.21 & 0.71 & 0.72 & 0.11 \\
\hline
\end{tabular}

Differences and mean equality tests, t-statistics in parenthesis, $*$ denotes significance at the $5 \%$-level:

Common law vs. French: $0.13(1.06)$

Common law vs. German: $0.25(2.49 *)$

Common law vs. Scandinavian: $-0.11(-1.08)$

German vs. French legal origins: $-0.12(-1.62)$

101 The English legal family includes Cyprus, Malta, and the UK.

102 The French legal family includes Belgium, Bulgaria, Spain, France, Italy, Luxembourg, and the Netherlands.

${ }^{103}$ The German legal family includes Austria, Switzerland, Germany, Greece, Hungary, Poland, Portugal, Slovenia, and the Slovak Republic.

104 The Scandinavian legal family includes Denmark, Finland, Norway, and Sweden.

105 For the variables "Executive/non-executive" and "Separation of chairman/CEO", the number of observations is 16 because the coding of the two Dutch codes is based on the two-tier board structure (see Appendix B, Table B.1), for which the two variables are not applicable.

${ }^{106}$ For the variables "Executive/non-executive" and "Separation of chairman/CEO", the number of observations is 7 because the two variables are not applicable to jurisdictions providing for a twotier board structure (which are most jurisdictions belonging to the German legal family, with the exception of Switzerland, Greece, and Portugal; these cases are discussed in Appendix B, Table B.1) 
Panel D. Investor-friendliness: qualitative vs. binary coding of board structure

\begin{tabular}{|c|c|c|c|c|c|c|c|c|c|c|}
\hline \multirow[t]{2}{*}{ Observations } & \multicolumn{2}{|c|}{$\begin{array}{c}\text { Full sample } \\
52^{107}\end{array}$} & \multicolumn{2}{|c|}{$\underset{6}{\text { English }}$} & \multicolumn{2}{|c|}{$\begin{array}{c}\text { French } \\
18^{108}\end{array}$} & \multicolumn{2}{|c|}{$\begin{array}{c}\text { German } \\
20^{109}\end{array}$} & \multicolumn{2}{|c|}{$\begin{array}{c}\text { Scandinavian } \\
8\end{array}$} \\
\hline & $\begin{array}{l}\text { Mean } \\
\text { qualitative }\end{array}$ & Mean binary & $\begin{array}{l}\text { Mean } \\
\text { qualitative }\end{array}$ & Mean binary & $\begin{array}{l}\text { Mean } \\
\text { qualitative }\end{array}$ & Mean binary & $\begin{array}{l}\text { Mean } \\
\text { qualitative }\end{array}$ & Mean binary & $\begin{array}{l}\text { Mean } \\
\text { qualitative }\end{array}$ & Mean binary \\
\hline $\begin{array}{l}\text { Executive/non- } \\
\text { executive }\end{array}$ & 0.628 & 0.568 & 0.42 & 0.33 & 0.53 & 0.44 & 0.61 & 0.57 & 1 & 1 \\
\hline $\begin{array}{l}\text { Number of in- } \\
\text { dependent } \\
\text { directors }\end{array}$ & 0.565 & 0.462 & 1 & 1 & 0.46 & 0.28 & 0.38 & 0.3 & 0.94 & 0.88 \\
\hline $\begin{array}{l}\text { Definition of } \\
\text { independence }\end{array}$ & 0.463 & 0.442 & 0.43 & 0.33 & 0.51 & 0.56 & 0.37 & 0.25 & 0.62 & 0.75 \\
\hline $\begin{array}{l}\text { Separation of } \\
\text { chairman/CEO }\end{array}$ & 0.53 & 0.649 & 0.71 & 0.83 & 0.45 & 0.56 & 0.11 & 0.29 & 0.94 & 1 \\
\hline $\begin{array}{l}\text { Cooling-off } \\
\text { period for CEO }\end{array}$ & 0.119 & 0.192 & 0.33 & 0.33 & 0.11 & 0.11 & 0.08 & 0.25 & 0.06 & 0.13 \\
\hline $\begin{array}{l}\text { Committee } \\
\text { structure }\end{array}$ & 0.624 & 0.888 & 0.75 & 0.95 & 0.68 & 0.93 & 0.51 & 0.84 & 0.69 & 0.88 \\
\hline $\begin{array}{l}\text { Total board } \\
\text { structure }\end{array}$ & & 0.525 & 0.61 & 0.63 & 0.47 & 0.5 & 0.35 & 0.42 & 0.71 & 0.77 \\
\hline $\begin{array}{l}\text { Diff. of means } \\
\text { (total board } \\
\text { structure) } \text { ) }^{110}\end{array}$ & $0.05^{* * *}$ & & 0.024 & & 0.025 & & $0.074 * *$ & & $0.061^{* *}$ & \\
\hline
\end{tabular}

10737 Observations for the variables "Executive/non-executive" and "Separation of chairman/CEO".

108 See n 105 above.

${ }^{109}$ See $n 106$ above.

110 Paired mean equality test. ${ }^{* *}$ denotes significance at the 1 percent level, ${ }^{* *}$ denotes significance at the 5 percent level. 


\section{Table 7. Sophistication I}

The table reports OLS estimates with robust standard errors clustered on country level. Dependent variable is the investor-friendliness of corporate governance codes, measured on the basis of the board structure proxy. The composition of the corporate governance committee follows the first method of computation as explained in the article. A higher value indicates a higher level of investor-friendliness of the code and a greater disposition of the committee members towards investor protection, respectively. Sophistication is measured by using the UK corporate governance codes and Commission Recommendation 2005/162/EC as a benchmark (level of investor protection based on the rules in force in the yeat before adoption of the response code). Columns (1)-(6) include the full sample except Luxembourg and the UK, (7) is a robustness check with Luxembourg included.

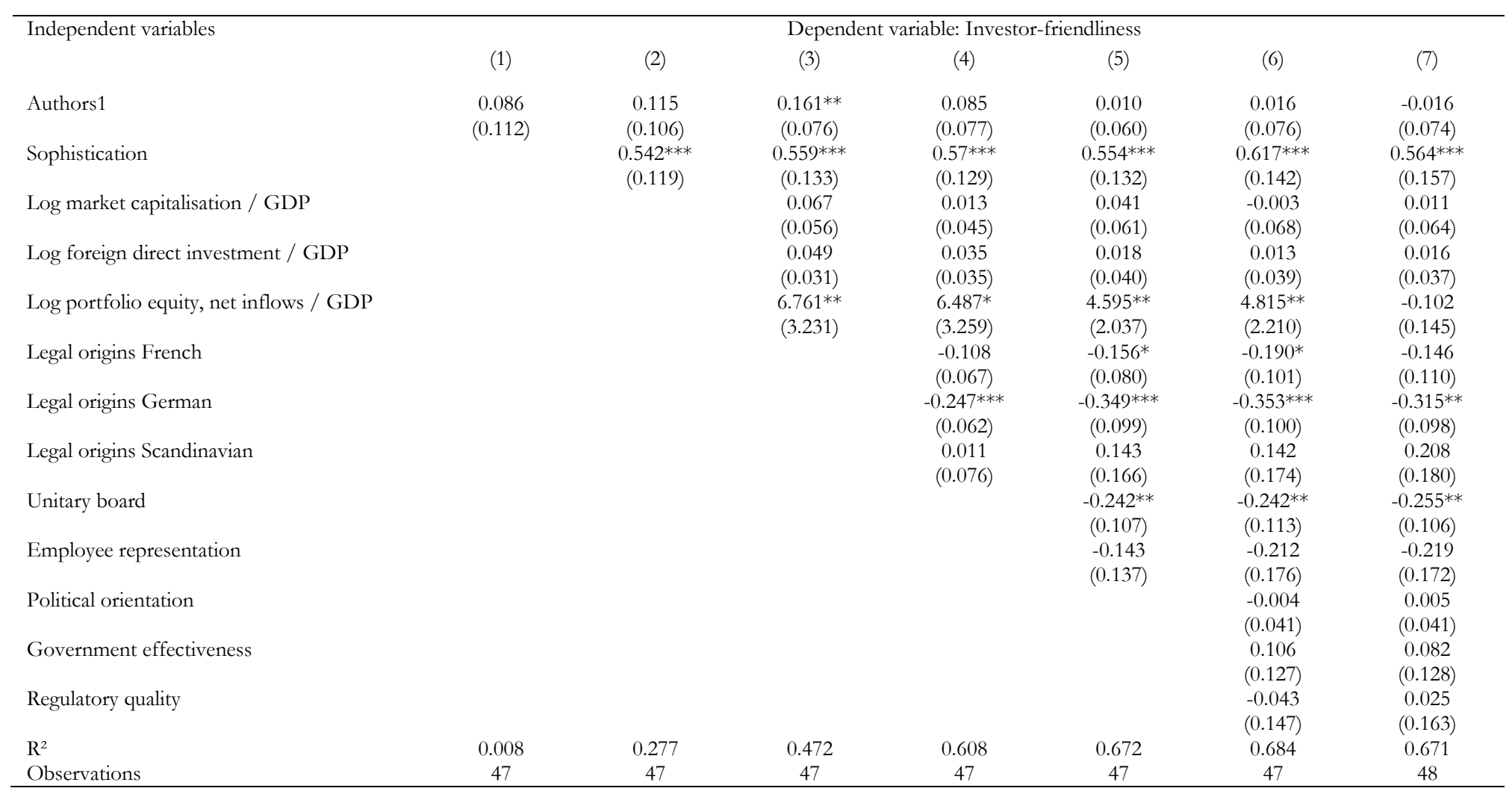

*** Significant at the 1 percent level. ** Significant at the 5 percent level. * Significant at the 10 percent level.

Robust standard errors are shown in parentheses. 
Table 8. Sophistication II

The table reports OLS estimates with robust standard errors clustered on country level. Dependent variable is the investor-friendliness of corporate governance codes, measured on the basis of the board structure proxy. The composition of the corporate governance committee follows the first method of computation as explained in the article. Sophistication of the corporate governance debate is measured as the time lag between the first comprehensive corporate governance initiative in Europe (Cadbury report) and the adoption of the respective code. Columns (1)-(6) include the full sample except Luxembourg, (7) is a robustness check with Luxembourg included.

Independent variables

Authors1

Sophistication

Log market capitalisation / GDP

Log foreign direct investment / GDP

Log portfolio equity, net inflows / GDP

Legal origins French

Legal origins German

Legal origins Scandinavian

Unitary board

Employee representation

Political orientation

Government effectiveness

Regulatory quality

$\mathrm{R}^{2}$

Observations
(1)

0.105

(0.113)

(2)

\subsection{9}

(0.115)

$0.028^{* * *}$
$(0.005)$

(0.005)

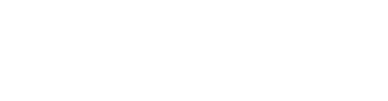

\section{Dependent variable: Investor-friendliness}

$\begin{array}{ccc}0.151^{*} & 0.059 & -0.004 \\ (0.083) & (0.076) & (0.065)\end{array}$

$\begin{array}{lll}0.151 * & & -0.004 \\ (0.083) & (0.076) & (0.065)\end{array}$

$\begin{array}{ccc}(0.083) & (0.076) & (0.065) \\ 0.028^{* * *} & 0.030^{* * *} & 0.029^{* * *}\end{array}$

(0.005)

0.076

$(0.054)$

$0.055^{*}$
$(0.030)$

$(0.030)$
$6.90 * * *$

(2.304)

$(0.005)$
0.017

(0.043)

0.043
$(0.032)$

$(0.032)$
$5.93 * * *$

$5.93^{* * *}$
$(2.019)$

$(2.019)$
$-0.159 * *$

(0.067)

$-0.274 * * *$

(0.076)

-0.034
$(0.039)$

$(0.005)$
0.044

0.044
$(0.055)$

0.026

0.026
$(0.037)$

$(0.037)$
$4.404 * *$

(1.767)

-0.191 ***

(0.043)

$-0.366^{* * *}$

$-0.366^{* * *}$
$(0.071)$

0.070
$(0.152)$

$(0.152)$
$-0.218^{*}$

(0.109)

$(0.109)$
-0.105

(0.145)
(6)

$-0.012$

$(0.072)$

$0.032^{* * *}$

(0.006)

0.012

(0.067)

0.024

(0.036)

$4.026^{* *}$

(1.718)

$-0.225^{* *}$

(0.082)

-0.391 ***

-0.391 ***
$(0.078)$

0.065

(0.164)

$-0.224 *$

(0.116)

$-0.164$

-0.164
$(0.187)$

$(0.187)$
0.034

0.034
$(0.032)$

0.110

(0.131)

$(0.131)$
-0.071

$(0.127)$
0.691
(7)

$-0.039$

$(0.070)$

0.031 ***

(0.006)

0.024
$(0.065)$

0.023

(0.034)

$-0.068$

(0.149)

$-0.232^{* *}$

$(0.087)$
$-0.405^{* * *}$

$(0.079)$

0.082

(0.166)

$-0.244^{* *}$

(0.108)

$-0.185$

(0.181)

0.055

(0.034)

0.121

(0.129)

$-0.043$

(0.140)

0.679

*** Significant at the 1 percent level. ** Significant at the 5 percent level. * Significant at the 10 percent level. Robust standard errors are shown in parentheses. 


\section{Table 9. Authors}

The table reports in columns (1)-(6) OLS estimates with clustered standard errors based on the model with the best fit derived from Tables 7 and 8 (equation (5) of each table), but varies the calculation of the composition of the corporate governance committee as explained in the article (Authors1, Authors2, and Authors3).

\begin{tabular}{|c|c|c|c|c|c|c|}
\hline \multirow[t]{2}{*}{ Independent variables } & \multicolumn{6}{|c|}{ Dependent variable: Investor-friendliness } \\
\hline & (1) & (2) & (3) & (4) & (5) & (6) \\
\hline Authors1 & $\begin{array}{c}0.010 \\
(0.060)\end{array}$ & & & $\begin{array}{l}-0.004 \\
(0.065)\end{array}$ & & \\
\hline Authors2 & & $\begin{array}{c}0.021 \\
(0.053)\end{array}$ & & & $\begin{array}{c}0.002 \\
(0.059)\end{array}$ & \\
\hline Authors 3 & & & $\begin{array}{c}0.029 \\
(0.058)\end{array}$ & & & $\begin{array}{c}0.030 \\
(0.051)\end{array}$ \\
\hline Sophistication I & $\begin{array}{c}0.554 * * * \\
(0.132)\end{array}$ & $\begin{array}{c}0.556^{* * *} \\
(0.132)\end{array}$ & $\begin{array}{c}0.554 * * * \\
(0.133)\end{array}$ & & & \\
\hline Sophistication II & & & & $\begin{array}{c}0.029^{* * *} \\
(0.005)\end{array}$ & $\begin{array}{c}0.029 * * * \\
(0.005)\end{array}$ & $\begin{array}{c}0.029 * * * \\
(0.005)\end{array}$ \\
\hline Log market capitalisation / GDP & $\begin{array}{c}0.041 \\
(0.061)\end{array}$ & $\begin{array}{c}0.043 \\
(0.062)\end{array}$ & $\begin{array}{c}0.045 \\
(0.063)\end{array}$ & $\begin{array}{c}0.044 \\
(0.055)\end{array}$ & $\begin{array}{c}0.045 \\
(0.057)\end{array}$ & $\begin{array}{c}0.049 \\
(0.058)\end{array}$ \\
\hline Log foreign direct investment / GDP & $\begin{array}{c}0.018 \\
(0.040)\end{array}$ & $\begin{array}{c}0.017 \\
(0.040)\end{array}$ & $\begin{array}{c}0.017 \\
(0.040)\end{array}$ & $\begin{array}{c}0.026 \\
(0.037)\end{array}$ & $\begin{array}{c}0.026 \\
(0.037)\end{array}$ & $\begin{array}{c}0.025 \\
(0.037)\end{array}$ \\
\hline Log portfolio equity, net inflows / GDP & $\begin{array}{c}4.595^{* *} \\
(2.037)\end{array}$ & $\begin{array}{c}4.648^{* *} \\
(2.007)\end{array}$ & $\begin{array}{c}4.679 * * \\
(1.936)\end{array}$ & $\begin{array}{c}4.404 * * \\
(1.767)\end{array}$ & $\begin{array}{l}4.426^{*} \\
(1.737)\end{array}$ & $\begin{array}{c}4.608^{* *} \\
(1.746)\end{array}$ \\
\hline Legal origins French & $\begin{array}{c}-0.156^{*} \\
(0.080)\end{array}$ & $\begin{array}{l}-0.153 \\
(0.076)\end{array}$ & $\begin{array}{l}-0.142 \\
(0.074)\end{array}$ & $\begin{array}{c}-0.191 \text { *** } \\
(0.043)\end{array}$ & $\begin{array}{c}-0.190^{* * *} \\
(0.044)\end{array}$ & $\begin{array}{c}-0.178^{* * * *} \\
(0.041)\end{array}$ \\
\hline Legal origins German & $\begin{array}{c}-0.349 * * * \\
(0.099)\end{array}$ & $\begin{array}{c}-0.345^{* * *} \\
(0.099)\end{array}$ & $\begin{array}{c}-0.337 * * * \\
(0.096)\end{array}$ & $\begin{array}{c}-0.366^{* * *} \\
(0.071)\end{array}$ & $\begin{array}{c}-0.365^{* * *} \\
(0.070)\end{array}$ & $\begin{array}{c}-0.356^{* * *} \\
(0.066)\end{array}$ \\
\hline Legal origins Scandinavian & $\begin{array}{c}0.143 \\
(0.166)\end{array}$ & $\begin{array}{c}0.138 \\
(0.169)\end{array}$ & $\begin{array}{c}0.137 \\
(0.165)\end{array}$ & $\begin{array}{c}0.070 \\
(0.152)\end{array}$ & $\begin{array}{c}0.069 \\
(0.155)\end{array}$ & $\begin{array}{c}0.057 \\
(0.153)\end{array}$ \\
\hline Unitary board & $\begin{array}{c}-0.242^{* *} \\
(0.107)\end{array}$ & $\begin{array}{c}-0.238^{* *} \\
(0.105)\end{array}$ & $\begin{array}{c}-0.236^{* *} \\
(0.102)\end{array}$ & $\begin{array}{l}-0.218^{*} \\
(0.109)\end{array}$ & $\begin{array}{l}-0.217^{*} \\
(0.107)\end{array}$ & $\begin{array}{l}-0.210^{*} \\
(0.104)\end{array}$ \\
\hline Employee representation & $\begin{array}{l}-0.143 \\
(0.137)\end{array}$ & $\begin{array}{l}-0.137 \\
(0.140)\end{array}$ & $\begin{array}{l}-0.131 \\
(0.140)\end{array}$ & $\begin{array}{l}-0.105 \\
(0.145)\end{array}$ & $\begin{array}{l}-0.103 \\
(0.149)\end{array}$ & $\begin{array}{l}-0.089 \\
(0.148)\end{array}$ \\
\hline $\mathrm{R}^{2}$ & 0.672 & 0.673 & 0.674 & 0.684 & 0.684 & 0.681 \\
\hline Observations & 47 & 47 & 47 & 51 & 51 & 51 \\
\hline
\end{tabular}

*** Significant at the 1 percent level. ** Significant at the 5 percent level. * Significant at the 10 percent level. Robust standard errors are shown in parentheses. 
Table 10. Binary coding of the board structure variable

The table reports OLS estimates with clustered standard errors based on the model with the best fit derived from Tables 7 and 8 (equation (5) of each table). The dependant variable (board structure) is calculated in a binary way as explained in Appendix B.7.

\begin{tabular}{|c|c|c|c|c|c|c|}
\hline \multirow[t]{2}{*}{ Independent variables } & \multicolumn{6}{|c|}{ Dependent variable: Investor-friendliness } \\
\hline & (1) & (2) & (3) & (4) & (5) & (6) \\
\hline Authors1 & $\begin{array}{l}-0.058 \\
(0.092)\end{array}$ & & & $\begin{array}{l}-0.065 \\
(0.097)\end{array}$ & & \\
\hline Authors2 & & $\begin{array}{l}-0.032 \\
(0.084)\end{array}$ & & & $\begin{array}{l}-0.048 \\
(0.091)\end{array}$ & \\
\hline Authors3 & & & $\begin{array}{l}-0.014 \\
(0.087)\end{array}$ & & & $\begin{array}{c}0.000 \\
(0.082)\end{array}$ \\
\hline Sophistication I & $\begin{array}{c}0.638^{* * *} \\
(0.121)\end{array}$ & $\begin{array}{c}0.641^{* * * *} \\
(0.122)\end{array}$ & $\begin{array}{c}0.645^{* * *} \\
(0.126)\end{array}$ & & & \\
\hline Sophistication II & & & & $\begin{array}{c}0.035^{* * *} \\
(0.005)\end{array}$ & $\begin{array}{c}0.035^{* * *} \\
(0.005)\end{array}$ & $\begin{array}{c}0.035^{* * *} \\
(0.006)\end{array}$ \\
\hline Log market capitalisation / GDP & $\begin{array}{c}0.027 \\
(0.087)\end{array}$ & $\begin{array}{c}0.027 \\
(0.090)\end{array}$ & $\begin{array}{c}0.029 \\
(0.090)\end{array}$ & $\begin{array}{c}0.027 \\
(0.080)\end{array}$ & $\begin{array}{c}0.025 \\
(0.083)\end{array}$ & $\begin{array}{c}0.032 \\
(0.083)\end{array}$ \\
\hline Log foreign direct investment / GDP & $\begin{array}{l}-0.009 \\
(0.044)\end{array}$ & $\begin{array}{l}-0.009 \\
(0.045)\end{array}$ & $\begin{array}{l}-0.010 \\
(0.045)\end{array}$ & $\begin{array}{c}0.002 \\
(0.039)\end{array}$ & $\begin{array}{c}0.002 \\
(0.040)\end{array}$ & $\begin{array}{c}0.000 \\
(0.040)\end{array}$ \\
\hline Log portfolio equity, net inflows / GDP & $\begin{array}{l}5.548^{*} \\
(3.055)\end{array}$ & $\begin{array}{l}5.712^{*} \\
(3.066)\end{array}$ & $\begin{array}{l}5.802^{*} \\
(3.045)\end{array}$ & $\begin{array}{c}5.548^{* *} \\
(2.354)\end{array}$ & $\begin{array}{c}5.604^{* *} \\
(2.305)\end{array}$ & $\begin{array}{c}5.769 * * \\
(2.365)\end{array}$ \\
\hline Legal origins French & $\begin{array}{c}-0.183^{* *} \\
(0.080)\end{array}$ & $\begin{array}{c}-0.184^{* *} \\
(0.083)\end{array}$ & $\begin{array}{c}-0.185^{*} \\
(0.092)\end{array}$ & $\begin{array}{c}-0.215^{* * *} \\
(0.056)\end{array}$ & $\begin{array}{c}-0.216^{* * *} \\
(0.060)\end{array}$ & $\begin{array}{c}-0.204^{* * *} \\
(0.061)\end{array}$ \\
\hline Legal origins German & $\begin{array}{c}-0.391 * * * \\
(0.137)\end{array}$ & $\begin{array}{c}-0.391 * * * \\
(0.137)\end{array}$ & $\begin{array}{c}-0.390 * * * \\
(0.136)\end{array}$ & $\begin{array}{c}-0.402 * * * \\
(0.101)\end{array}$ & $\begin{array}{c}-0.401 \text { *** } \\
(0.101)\end{array}$ & $\begin{array}{c}-0.389 * * * \\
(0.095)\end{array}$ \\
\hline Legal origins Scandinavian & $\begin{array}{c}0.006 \\
(0.224)\end{array}$ & $\begin{array}{c}0.000 \\
(0.227)\end{array}$ & $\begin{array}{l}-0.008 \\
(0.225)\end{array}$ & $\begin{array}{l}-0.077 \\
(0.209)\end{array}$ & $\begin{array}{l}-0.075 \\
(0.213)\end{array}$ & $\begin{array}{l}-0.091 \\
(0.212)\end{array}$ \\
\hline Unitary board & $\begin{array}{l}-0.198 \\
(0.178)\end{array}$ & $\begin{array}{l}-0.194 \\
(0.177)\end{array}$ & $\begin{array}{l}-0.189 \\
(0.177)\end{array}$ & $\begin{array}{l}-0.165 \\
(0.186)\end{array}$ & $\begin{array}{l}-0.164 \\
(0.185)\end{array}$ & $\begin{array}{l}-0.150 \\
(0.184)\end{array}$ \\
\hline Employee representation & $\begin{array}{l}-0.002 \\
(0.198)\end{array}$ & $\begin{array}{l}-0.002 \\
(0.203)\end{array}$ & $\begin{array}{c}0.002 \\
(0.206)\end{array}$ & $\begin{array}{c}0.043 \\
(0.204)\end{array}$ & $\begin{array}{c}0.040 \\
(0.210)\end{array}$ & $\begin{array}{c}0.056 \\
(0.212)\end{array}$ \\
\hline $\mathrm{R}^{2}$ & 0.555 & 0.554 & 0.553 & 0.591 & 0.59 & 0.588 \\
\hline Observations & 47 & 47 & 47 & 51 & 51 & 51 \\
\hline
\end{tabular}

*** Significant at the 1 percent level. ** Significant at the 5 percent level. * Significant at the 10 percent level.

Robust standard errors are shown in parentheses. 
Table 11. Structural equation model

Panel A. Factor analysis of investor friendliness of corporate governance codes

The table reports estimates for a single-factor confirmatory model, including the elements of the board structure variable that are applicable to all codes (i.e. excluding "Distinction between executive and nonexecutive directors" and "Separation of chairman and CEO"). The column "R" ${ }^{2}$ " reports the squared correlations between the indicator and the latent variable (investor-friendliness of corporate governance codes) for each measurement equation (communality). The estimates are based on all observations, including the UK codes.

\begin{tabular}{lcc}
\hline Element & Parameter estimate & $\mathrm{R}^{2}$ \\
Number of independent directors & 1 & 0.354 \\
& & \\
Definition of independence & $0.845^{* * *}$ & 0.484 \\
& $(0.22)$ & 0.161 \\
Cooling-off period & $0.483^{* *}$ & \\
& $(0.19)$ & 0.841 \\
Committee structure & $1.186^{* * *}$ & \\
& $(0.624)$ & \\
\hline
\end{tabular}

*** Significant at the 1 percent level. ** Significant at the 5 percent level. * Significant at the 10 percent level.

Standard errors are shown in parentheses.

Panel B. Residuals of the fitted values and the sample

The table reports the differences (residuals) between the fitted correlation matrix and the matrix computed from the sample.

\begin{tabular}{l|cccc} 
& $\begin{array}{l}\text { Number } \\
\text { ind. dir. }\end{array}$ & $\begin{array}{l}\text { Def. ind. } \\
\text { dir. }\end{array}$ & $\begin{array}{l}\text { Cooling- } \\
\text { off }\end{array}$ & Comm. \\
\hline $\begin{array}{l}\text { Number of in- } \\
\text { dependent directors }\end{array}$ & -0.000 & & & \\
$\begin{array}{l}\text { Definition of } \\
\text { independence }\end{array}$ & 0.001 & 0.000 & & \\
$\begin{array}{l}\text { Cooling-off period } \\
\text { for CEO }\end{array}$ & 0.013 & -0.007 & 0.000 & \\
$\begin{array}{l}\text { Committee } \\
\text { structure }\end{array}$ & -0.001 & 0.001 & 0.000 & 0.000
\end{tabular}


Panel C. Structural model with measurement part

The table reports estimates for a structural equation model with a measurement part as discussed above in Panel A, i.e. investor-friendliness of corporate governance codes is latent dependant variable and the four variables "Number of independent directors", "Definition of independence", "Cooling-off period", and "Committee structure" are indicator variables. "Sophistication I" refers to the UK corporate governance codes as benchmarks and "Sophistication II" to the time lag between the first comprehensive corporate governance initiative in Europe (Cadbury report) and the adoption of the respective code. The sample for (1) excludes the UK codes and Luxembourg, (2) excludes only Luxembourg. Standard errors are clustered by country.

\begin{tabular}{|c|c|c|}
\hline \multicolumn{3}{|l|}{ Independent variables } \\
\hline & (1) & (2) \\
\hline Authors1 & $\begin{array}{l}-0.085 \\
(0.067)\end{array}$ & $\begin{array}{l}-0.109 \\
(0.077)\end{array}$ \\
\hline Sophistication I & $\begin{array}{c}0.771 * * * \\
(0.186)\end{array}$ & \\
\hline Sophistication II & & $\begin{array}{c}0.039 * * * \\
(0.007)\end{array}$ \\
\hline Ratio market capitalisation / GDP & $\begin{array}{c}0.041 \\
(0.071)\end{array}$ & $\begin{array}{c}0.048 \\
(0.065)\end{array}$ \\
\hline Foreign direct investment & $\begin{array}{l}-0.016 \\
(0.048)\end{array}$ & $\begin{array}{l}-0.001 \\
(0.044)\end{array}$ \\
\hline Portfolio equity, net inflows & $\begin{array}{c}7.301 * * \\
(2.910)\end{array}$ & $\begin{array}{c}5.549 * * \\
(2.326)\end{array}$ \\
\hline Legal origins French & $\begin{array}{c}-0.236^{* *} \\
(0.120)\end{array}$ & $\begin{array}{c}-0.252^{* * *} \\
(0.088)\end{array}$ \\
\hline Legal origins German & $\begin{array}{c}-0.469 * * * \\
(0.135)\end{array}$ & $\begin{array}{c}-0.476 * * * \\
(0.115)\end{array}$ \\
\hline Legal origins Scandinavian & $\begin{array}{l}-0.053 \\
(0.166)\end{array}$ & $\begin{array}{l}-0.094 \\
(0.153)\end{array}$ \\
\hline Unitary board & $\begin{array}{c}-0.264^{* *} \\
(0.116)\end{array}$ & $\begin{array}{c}-0.267^{* *} \\
(0.131)\end{array}$ \\
\hline Employee representation & $\begin{array}{l}-0.165 \\
(0.137)\end{array}$ & $\begin{array}{l}-0.121 \\
(0.154)\end{array}$ \\
\hline Observations & 47 & 51 \\
\hline
\end{tabular}

The other measures of author (Author2 and Author3) are not significant at the 10 percent level under model specifications both with Sophistication I and Sophistication II (results here omitted). 
Table 12. Evolution and convergence

Panel A. Comparison of means

We calculate mean and median for two subsamples. The first one comprises the first code adopted in each country between 1998 and 2004, the second one the most recent code from the interval 2005-2011. We omit countries with only one code. In countries with more than one code issuer, we pair the codes that influenced each other. For Belgium, these are 1998C and 2009 (omitting 1998E), for France 1995 (Vienot I) and 2010 (AFEP/MEDEF) as well as 1998 (AFG) and 2010 (AFG), for Germany 2000 and 2010 (omitting 2000B), for Greece we pair both 1999 and 2001 with 2011 since the latter code draws on both prior codes (see p. 4 of the 2011 code), for Poland 2002C and 2010 (see p. 2 of the 2010 code), for Spain 2003 and 2006 (omitting 2004; see p. 3 of the 2006 code), and for the UK 1998 and 2010. The table reports estimates of a paired mean equality test with t-statistics in parentheses.

\begin{tabular}{|c|c|c|c|c|c|}
\hline & \multicolumn{2}{|c|}{ 1998-2004 } & \multicolumn{2}{|c|}{ 2005-2011 } & \\
\hline & Mean & Median & Mean & Median & Diff. \\
\hline Board structure & 0.39 & 0.34 & 0.62 & 0.63 & $\begin{array}{l}-0.228^{* * *} \\
(-6.28)\end{array}$ \\
\hline Authors1 & 0.4 & 0.4 & 0.36 & 0.39 & $\begin{array}{l}0.044 \\
(1.07)\end{array}$ \\
\hline Observations & 19 & & 19 & & \\
\hline
\end{tabular}

*** Significant at the 1 percent level.

Panel B. Convergence by comparison of variance

We pair codes as described above in Panel A and compare the variances of the two subsamples 1998-2004 and 2005-2011 (only p-values are reported).

\begin{tabular}{|c|c|c|c|c|c|}
\hline & 1998-2004 & $2005-2011$ & \multicolumn{3}{|c|}{ P-values } \\
\hline & Std. Dev. & Std. Dev. & F-test & $\begin{array}{l}\text { Brown- } \\
\text { Forsythe }\end{array}$ & $\begin{array}{l}\text { Brown-F. } \\
\text { (median) }\end{array}$ \\
\hline Board structure & 0.23 & 0.2 & 0.59 & 0.84 & 0.86 \\
\hline Authors1 & 0.27 & 0.25 & 0.78 & 0.89 & 0.88 \\
\hline Observations & 19 & 19 & & & \\
\hline
\end{tabular}


Panel C. Convergence by variance of codes in force 1998-2011

For each year in the sample, we calculate mean, median, and standard deviation of all codes in force in that year. Codes are regarded as being "in force" if they have not been superseded by a newer code from the same issuer. Therefore, in some countries more than code may be in force in any given year (see, for example, France, where codes from two issuers, AFEP/MEDEF and AFG, are regularly updated).

\begin{tabular}{lllll}
\hline Year & \multicolumn{3}{c}{ Board structure } \\
\hline 1998 & Mean & Median & Std. Dev. & Obs. \\
1999 & 0.32 & 0.32 & 0.2 & 5 \\
2000 & 0.27 & 0.31 & 0.19 & 8 \\
2001 & 0.24 & 0.22 & 0.18 & 10 \\
2002 & 0.27 & 0.3 & 0.21 & 13 \\
2003 & 0.3 & 0.3 & 0.19 & 17 \\
2004 & 0.38 & 0.34 & 0.26 & 21 \\
2006 & 0.45 & 0.42 & 0.25 & 24 \\
2007 & 0.45 & 0.42 & 0.25 & 25 \\
2008 & 0.44 & 0.42 & 0.24 & 26 \\
2009 & 0.45 & 0.42 & 0.25 & 27 \\
2010 & 0.47 & 0.49 & 0.25 & 27 \\
2011 & 0.53 & 0.55 & 0.24 & 26 \\
\hline
\end{tabular}

Panel D. Convergence by difference between codes adopted on a rolling basis in the last three years (measured for 2000-2012) and all codes in force

\begin{tabular}{llllll}
\hline Year & \multicolumn{5}{l}{ Board structure } \\
\hline & $\begin{array}{l}\text { Mean of } \\
\text { codes in } \\
\text { force }\end{array}$ & $\begin{array}{l}\text { Number of } \\
\text { codes newly } \\
\text { adopted }\end{array}$ & $\begin{array}{l}\text { Mean of } \\
\text { codes newly } \\
\text { adopted }\end{array}$ & $\begin{array}{l}\text { Difference } \\
\text { between } \\
\text { means }\end{array}$ & $\begin{array}{l}\text { Std. Dev. of } \\
\text { codes newly } \\
\text { adopted }\end{array}$ \\
\hline 2000 & 0.24 & 7 & 0.26 & -0.02 & 0.2 \\
2001 & 0.27 & 9 & 0.23 & 0.04 & 0.19 \\
2002 & 0.3 & 8 & 0.24 & 0.06 & 0.22 \\
2003 & 0.38 & 11 & 0.29 & 0.09 & 0.19 \\
2004 & 0.45 & 15 & 0.45 & 0 & 0.26 \\
2006 & 0.45 & 17 & 0.51 & -0.06 & 0.23 \\
2007 & 0.44 & 13 & 0.6 & -0.16 & 0.19 \\
2008 & 0.45 & 9 & 0.49 & -0.04 & 0.19 \\
2009 & 0.47 & 7 & 0.52 & -0.05 & 0.27 \\
2010 & 0.53 & 8 & 0.61 & -0.08 & 0.24 \\
2011 & 0.57 & 14 & 0.66 & -0.09 & 0.21 \\
2012 & 0.57 & 14 & 0.61 & -0.04 & 0.2 \\
\hline
\end{tabular}




\section{Figures}

Figure 1. Corporate governance codes and composition of corporate governance committees over time (averages for board structure and authors1 of codes in force in any given year).

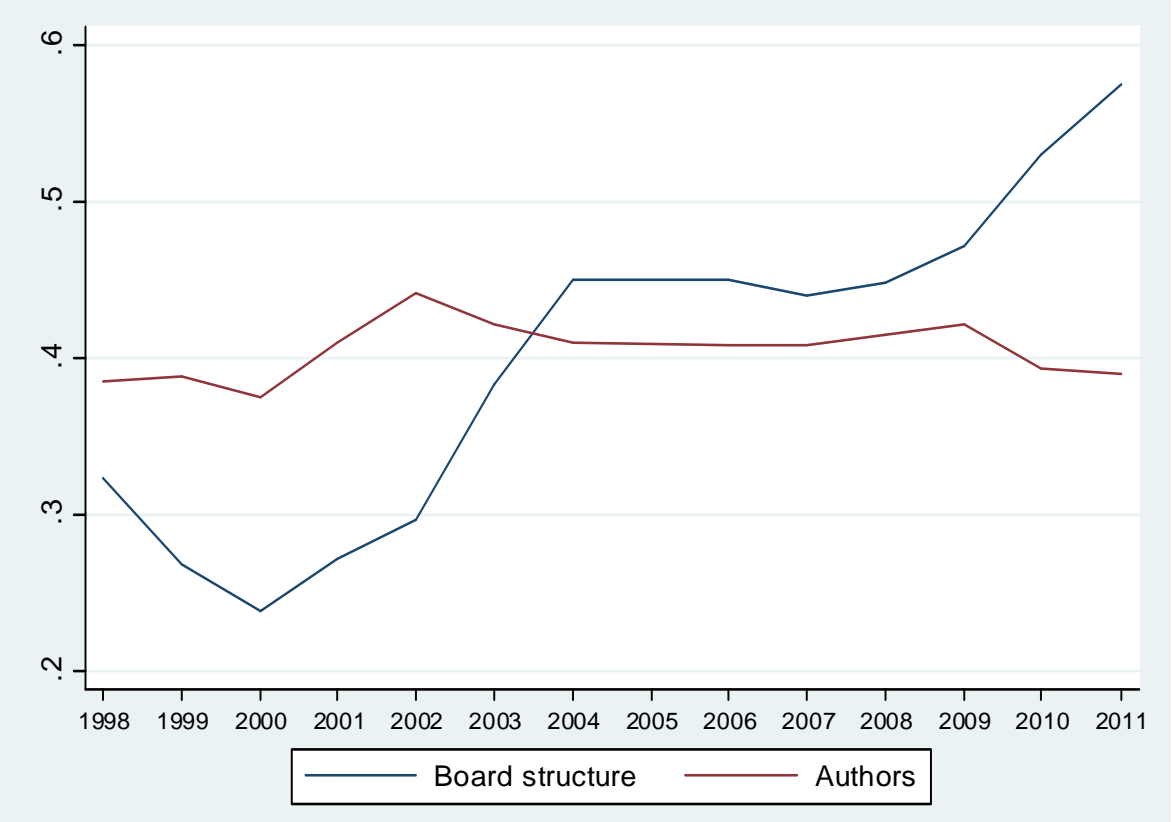


Figure 2. Partial-regression plot of the relationship between the regulation of board structure and the composition of corporate governance committees based on model specification (5) in Table 7.

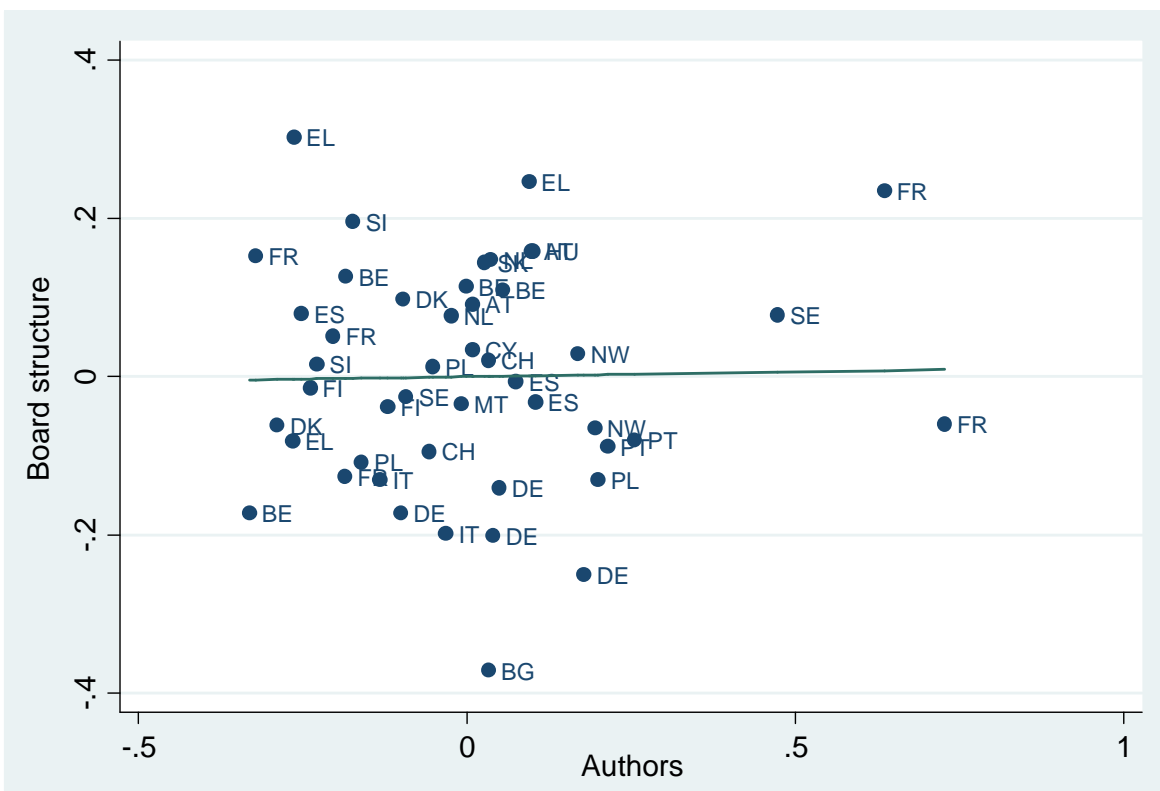

coef $=.01207843$, (robust) se $=.06032495, t=.2$ 
Figure 3. Partial-regression plot of the relationship between the regulation of board structure and the benchmark UK codes as a proxy for the diffusion of corporate governance innovations, based on model specification (5) in Table 7.

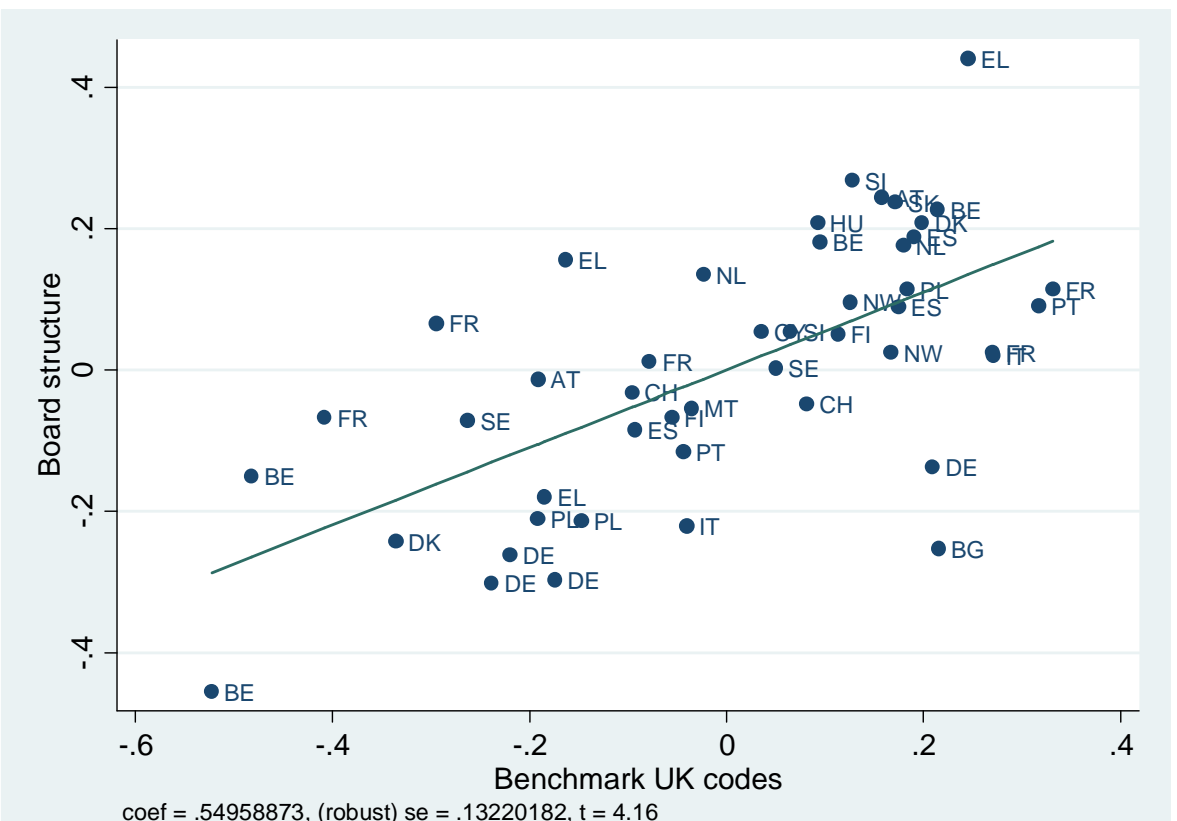

coef $=.54958873$, (robust) $\mathrm{se}=.13220182, \mathrm{t}=4.16$ 
Figure 4. Partial-regression plot of the relationship between the regulation of board structure and portfolio equity net inflows, based on model specification (5) in Table 7.

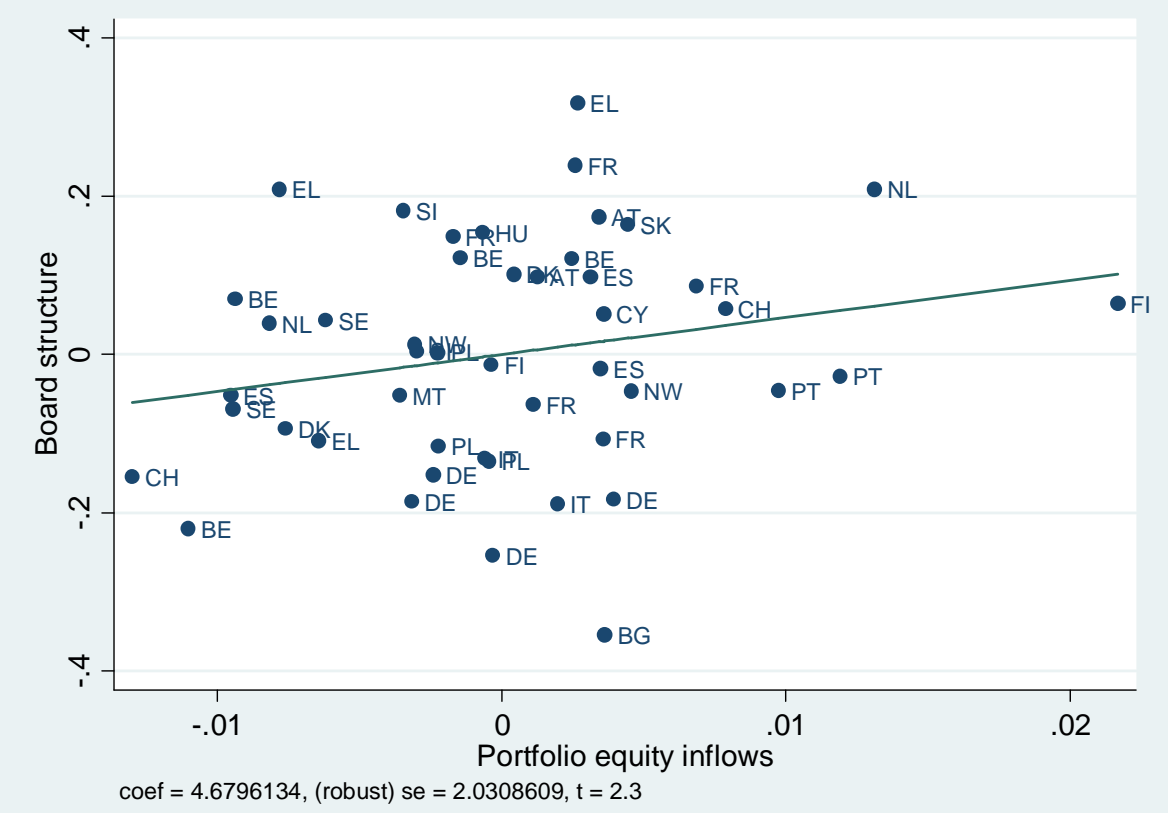


Figure 5. Partial-regression plot of the relationship between the regulation of board structure and unitary (one-tier) vs. dual (two-tier) board models, based on model specification (5) in Table 7.

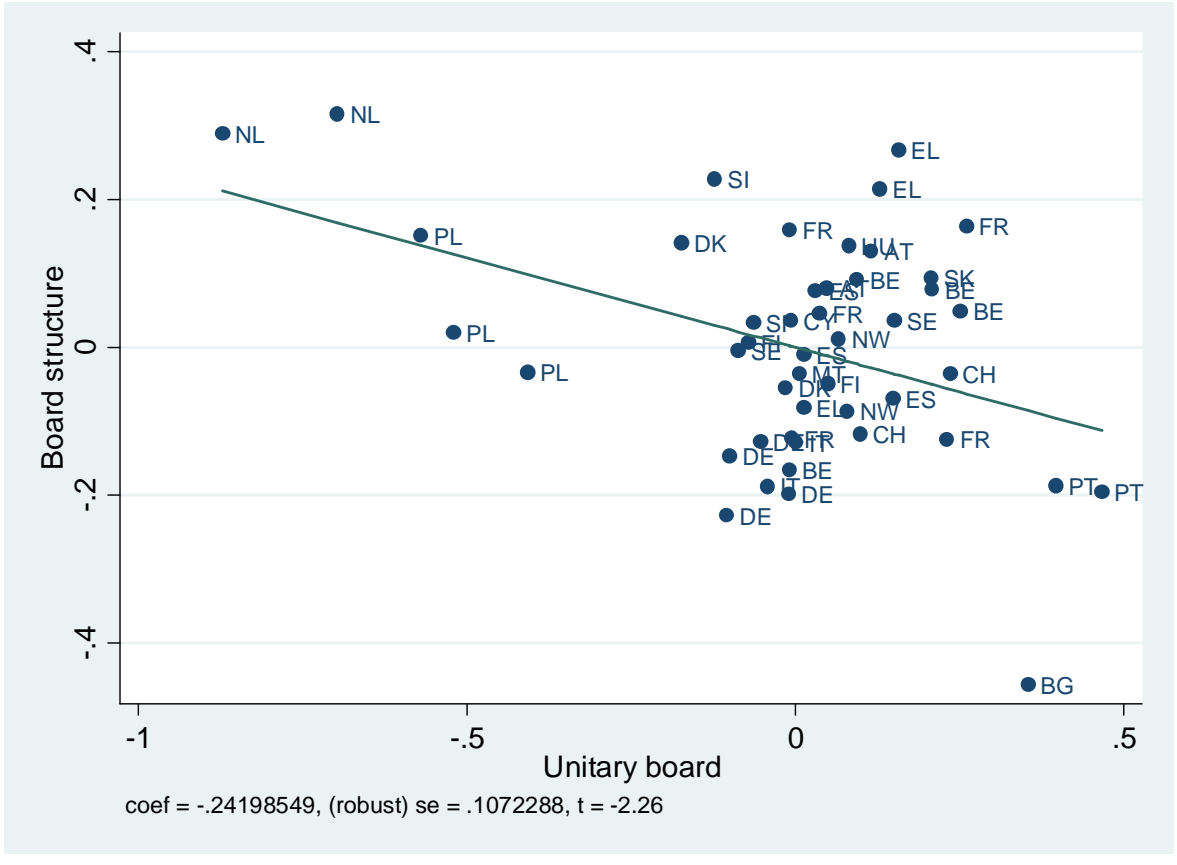


Figure 6. Partial-regression plot of the relationship between the regulation of board structure and the evolution of the corporate governance movement (measured as the number of years since the first major initiative in Europe, i.e. the Cadbury Report), based on model specification (5) in Table 8.

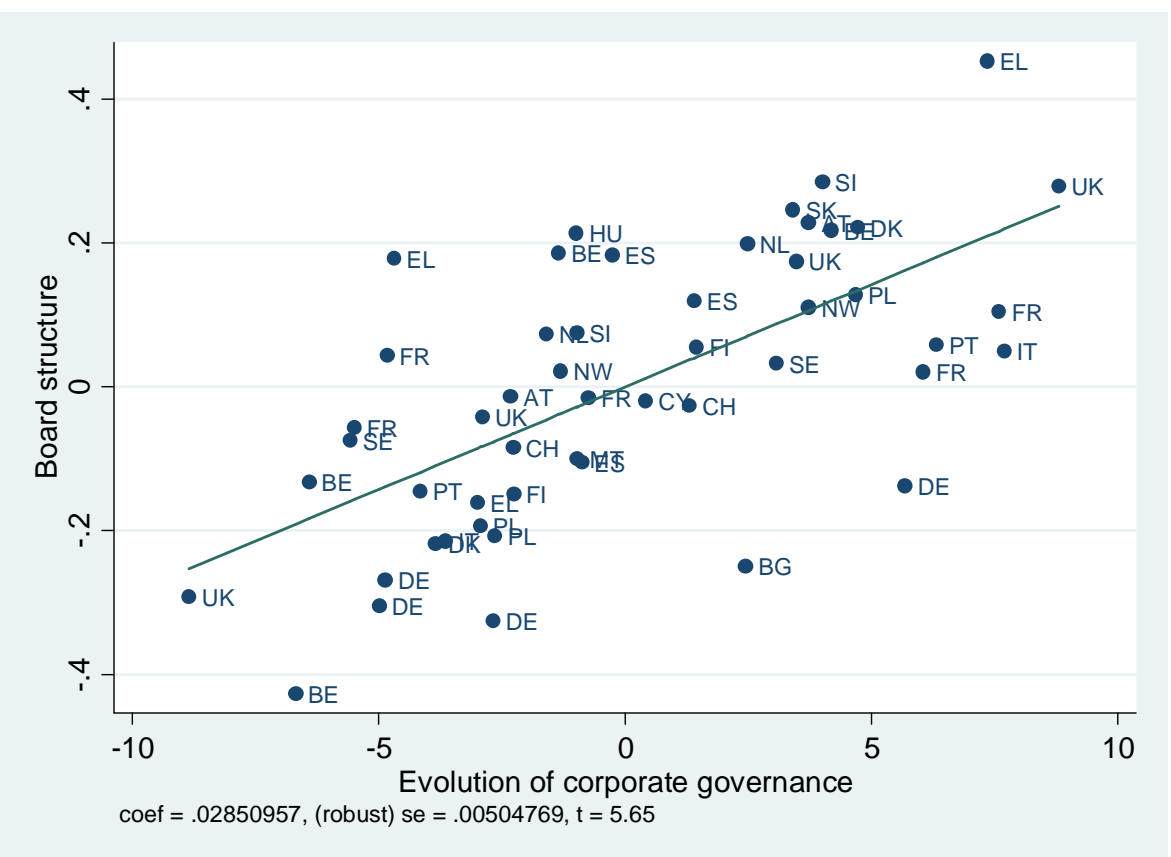


Appendix A: Definition of the board structure variable (STRUC)

Table A.1. Unitary boards

\begin{tabular}{|l|l|}
\hline Elements & Quantification \\
\hline \hline $\begin{array}{l}\text { (1) Distinction between } \\
\text { executive and non-executive } \\
\text { directors (EXD) }\end{array}$ & $\begin{array}{l}\text { Measured on a scale from 0 to 1 and shall be: } \\
\text { (a) } 1 \text { if the code requires a minimum proportion of non- } \\
\text { executive directors that should be at least one half; } \\
\text { (b) } 0.5 \text { if the code does not require half (or more) of the } \\
\text { board members to be non-executive directors, but specifies } \\
\text { a number or proportion of members that should be non- } \\
\text { executive directors (e.g., two members or one third); } \\
\text { (c) } 0 \text { if the code contains only general statements, such as } \\
\text { that the balance between executive and non-executive } \\
\text { directors should be 'appropriate'.1 }\end{array}$ \\
\hline $\begin{array}{l}\text { (2) Quantitative measure of } \\
\text { independence of non- } \\
\text { executive directors (NO_IND) }\end{array}$ & $\begin{array}{l}\text { Measured on a scale from 0 to 1 and shall be: } \\
\text { (a) } 1 \text { if the code requires that a majority of the non- } \\
\text { executive directors should be independent; } \\
\text { (b) 0.5 if the code does not require a majority of the non- } \\
\text { executive directors to be independent, but specifies a } \\
\text { number or proportion of members that should satisfy the } \\
\text { independence requirements (e.g., two members or one } \\
\text { third); } \\
\text { (c) 0 if the code contains only general statements, such as } \\
\text { that a 'sufficient number' of non-executive directors should } \\
\text { be independent.' }\end{array}$ \\
\hline $\begin{array}{l}\text { (3) Qualitative measure of } \\
\text { independence of non- } \\
\text { executive directors } \\
\text { (DEF_IND) }\end{array}$ & $\begin{array}{l}\text { EITHER measured on a scale from 0 to 1 by adding 0.1 } \\
\text { for each of the following criteria that the definition of } \\
\text { independence in the code contains:3 } \\
\text { (a) the director was not an executive director of the } \\
\text { company or an associated company for a period of time } \\
\text { not shorter than five years preceding his/her appointment; } \\
\text { (b) the director was not an executive director of the } \\
\text { company or an associated company for a period of time } \\
\text { not shorter than three years (or one year, in which case the } \\
\text { value to be added is } 0.05) \text { preceding his/her appointment } \\
\text { (if the code provides for a minimum period of five years or }\end{array}$ \\
\hline
\end{tabular}

\footnotetext{
${ }^{1}$ See e.g. UK Corporate Governance Code 2010, B.1, Supporting Principle: 'The board should include an appropriate combination of executive and non-executive directors (and, in particular, independent non-executive directors) such that no individual or small group of individuals can dominate the board's decision taking.'

2 See e.g. Commission Recommendation 2005/162/EC, Sec. 4: 'A sufficient number of independent non-executive or supervisory directors should be elected to the (supervisory) board of companies to ensure that any material conflict of interest involving directors will be properly dealt with.'

${ }^{3}$ The criteria listed in Annex II of Commission Recommendation 2005/162/EC are used, with some alterations, as a benchmark.

${ }^{4}$ Commission Recommendation 2005/162/EC, Annex II(1)(a).
} 


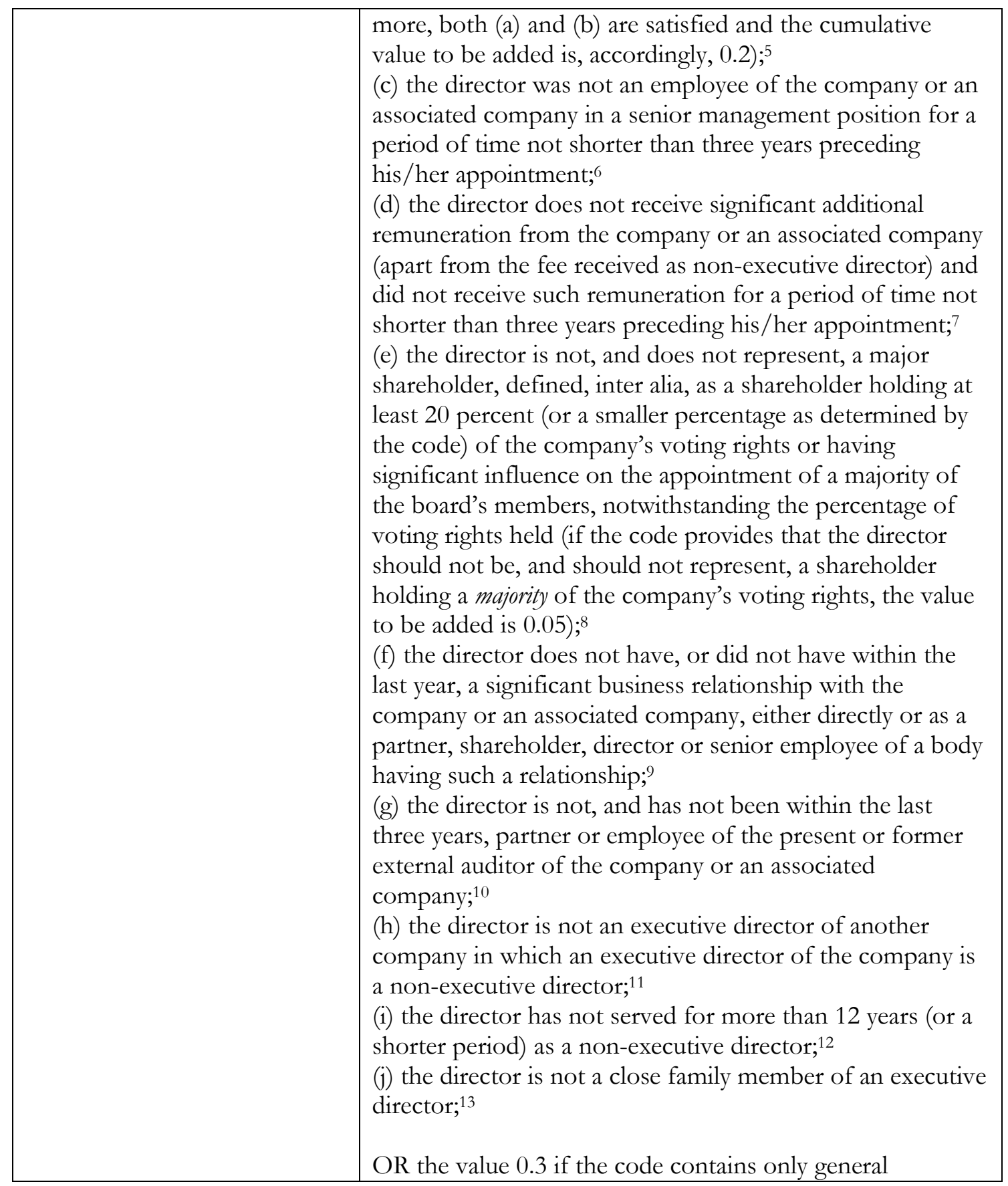

${ }^{5}$ Not contained in Commission Recommendation 2005/162/EC.

${ }^{6}$ Commission Recommendation 2005/162/EC, Annex II(1)(b).

7 Commission Recommendation 2005/162/EC defines 'additional remuneration' as follows: 'Such additional remuneration covers in particular any participation in a share option or any other performance-related pay scheme; it does not cover the receipt of fixed amounts of compensation under a retirement plan (including deferred compensation) for prior service with the company (provided that such compensation is not contingent in any way on continued service)', see Annex II(1)(c).

${ }^{8}$ Commission Recommendation 2005/162/EC requires that the director should not be, and should not represent, a 'controlling shareholder' and refers to Art 1(1) of council Directive 83/349/EEC for the determination of control, see Annex II(1)(d).

${ }^{9}$ Commission Recommendation 2005/162/EC, Annex II(1)(e).

${ }^{10}$ Commission Recommendation 2005/162/EC, Annex II(1)(f).

${ }^{11}$ Commission Recommendation 2005/162/EC, Annex II(1)(g).

${ }^{12}$ Commission Recommendation 2005/162/EC, Annex II(1)(h).

${ }_{13}$ Commission Recommendation 2005/162/EC, Annex II(1)(i). 


\begin{tabular}{|c|c|}
\hline & $\begin{array}{l}\text { statements, such as that independent directors should not } \\
\text { have any 'business or personal relationships' with the } \\
\text { company or its management; } \\
\text { OR, if the code contains both a list of criteria and general } \\
\text { statements, whichever of the above values is higher. }\end{array}$ \\
\hline $\begin{array}{l}\text { (4) Separation of chairman and } \\
\text { CEO (SEP) }\end{array}$ & $\begin{array}{l}\text { Measured on a scale from } 0 \text { to } 1 \text { and shall be: } \\
\text { (a) } 1 \text { if the CEO and chairman are separated; the roles } \\
\text { should not be exercised by the same individual; } \\
\text { (b) } 0 \text { if the same individual can be chairman of the board } \\
\text { and CEO. }\end{array}$ \\
\hline $\begin{array}{l}\text { (5) Cooling-off period for the } \\
\text { CEO to become chairman of } \\
\text { the board (COOL) }\end{array}$ & $\begin{array}{l}\text { Measured on a scale from } 0 \text { to } 1 \text { and shall be: } 14 \\
\text { (a) } 1 \text { if the CEO should not go on to be chairman of the } \\
\text { board for a period of at least five years after the end of } \\
\text { his / her tenure as CEO; } \\
\text { (b) } 0.7 \text { if the waiting period is at least three, but less than } \\
\text { five, years; } \\
\text { (c) } 0.4 \text { if the waiting period is at least one, but less than } \\
\text { three, years; } \\
\text { (d) } 0 \text { otherwise. }\end{array}$ \\
\hline $\begin{array}{l}\text { (6) Structures to mitigate } \\
\text { conflicts of interest (CON) })^{15} \\
\text { (a) Appointments to the board } \\
\text { (b) Responsibility for internal } \\
\text { control and appointment of } \\
\text { the external auditor } \\
\text { (c) Remuneration decisions }\end{array}$ & $\begin{array}{l}\text { (a) Appointments to the board: the variable is measured on } \\
\text { a scale from } 0 \text { to } 1 \text { and shall be: } \\
\text { (i) } 1 \text { if the code requires that a nomination } \\
\text { committee is set up within the board to make the } \\
\text { appointment decision or prepare the appointment decision } \\
\text { of the board and that the committee is composed of a } \\
\text { majority of independent non-executive directors; }{ }^{16} \\
\text { (ii) } 0.5 \text { if the code requires that a nomination } \\
\text { committee is set up within the board, but the code does not } \\
\text { require a majority of the board members to be independent } \\
\text { non-executive directors; } \\
\text { (iii) } 0 \text { if neither (i) nor (ii) are satisfied. } \\
\text { (b) Responsibility for internal control and appointment of } \\
\text { the external auditor: the variable is measures on a scale } \\
\text { from } 0 \text { to } 1 \text { and shall be: } \\
\text { (i) } 1 \text { if the code requires that an audit committee is } \\
\text { set up within the board to monitor the integrity of the } \\
\text { financial information provided by the company, review the } \\
\text { internal control and risk management systems, decide on, } \\
\text { or make recommendations with respect to, the selection, } \\
\text { appointment, and removal of the external auditor, and }\end{array}$ \\
\hline
\end{tabular}

${ }^{14}$ The values are based on the realistic assumption that the first year is more important than the following years in addressing potential conflicts of interest.

${ }^{15}$ Commission Recommendation 2005/162/EC identifies three conflicts of interest that are particularly important, see Sec. 5. The variable deals with these three conflicts.

${ }^{16}$ This is the benchmark according to Commission Recommendation 2005/162/EC, Annex I(2.1)(2). 


\begin{tabular}{|l|l|}
\hline $\begin{array}{r}\text { monitor the external auditor; and further if the code } \\
\text { requires that the committee is composed of a majority of } \\
\text { independent non-executive directors; }{ }^{17} \\
\text { (ii) } 0.5 \text { if the code requires that an audit committee } \\
\text { is set up within the board, but the code does not require a } \\
\text { majority of the board members to be independent non- } \\
\text { executive directors; } \\
\text { (iii) } 0 \text { if neither (i) nor (ii) are satisfied. }\end{array}$ \\
$\begin{array}{l}\text { (c) Remuneration decisions: the variable is measured on a } \\
\text { scale from } 0 \text { to } 1 \text { and shall be: } \\
\text { (i) } 1 \text { if the code requires that a remuneration } \\
\text { committee is set up within the board to determine the } \\
\text { remuneration of the executive directors or make proposals } \\
\text { for the determination of remuneration and that the } \\
\text { committee is composed of a majority of independent non- } \\
\text { executive directors; } 18 \\
\text { (ii) } 0.5 \text { if the code requires that a remuneration } \\
\text { committee is set up within the board, but the code does not } \\
\text { require a majority of the board members to be independent } \\
\text { non-executive directors; } \\
\text { (iii) } 0 \text { if neither (i) nor (ii) are satisfied. } \\
\text { The total value for 'Structures to mitigate conflicts of } \\
\text { interest' is the average of the above components, provided } \\
\text { that they are applicable. }\end{array}$ \\
\hline
\end{tabular}

\footnotetext{
17 Commission Recommendation 2005/162/EC, Annex I(4.1), requires that the committee should be composed exclusively of non-executive or supervisory directors and that a majority of its members should be independent. I have simplified the recommendation to focus on a criterion that is relevant for both unitary and dual board systems.

${ }_{18}$ Commission Recommendation 2005/162/EC, Annex I(3.1)(2), requires that the committee should be composed exclusively of non-executive or supervisory directors and that a majority of its members should be independent. I have simplified the recommendation to focus on a criterion that is relevant for both unitary and dual board systems.
} 
Table A.2. Dual boards ${ }^{19}$

\begin{tabular}{|c|c|}
\hline Elements & Quantification \\
\hline $\begin{array}{l}\text { (1) Distinction between } \\
\text { executive and non-executive } \\
\text { directors (EXD) }\end{array}$ & $\begin{array}{l}\text { Not applicable, since the distinction between executive and } \\
\text { non-executive directors is built into the structure of two- } \\
\text { tier boards. }\end{array}$ \\
\hline $\begin{array}{l}\text { (2) Quantitative measure of } \\
\text { independence of members of } \\
\text { the supervisory board } \\
\text { (NO_IND) }\end{array}$ & $\begin{array}{l}\text { Measured on a scale from } 0 \text { to } 1 \text { and shall be: } \\
\text { (a) } 1 \text { if the code requires that a majority of the members of } \\
\text { the supervisory board should be independent; } \\
\text { (b) } 0.5 \text { if the code does not require a majority of the } \\
\text { members of the supervisory board to be independent, but } \\
\text { specifies a number or proportion of members that should } \\
\text { satisfy the independence requirements (e.g., two members } \\
\text { or one third); } \\
\text { (c) } 0 \text { if the code contains only general statements, such as } \\
\text { that a 'sufficient number' of members of the supervisory } \\
\text { board should be independent. }\end{array}$ \\
\hline $\begin{array}{l}\text { (3) Qualitative measure of } \\
\text { independence of members of } \\
\text { the supervisory board } \\
\text { (DEF_IND) }\end{array}$ & $\begin{array}{l}\text { As in Panel A, but replace 'executive director' by 'member } \\
\text { of the management board' and 'non-executive director' by } \\
\text { 'member of the supervisory board'. }\end{array}$ \\
\hline $\begin{array}{l}\text { (4) Separation of chairman and } \\
\text { CEO (SEP) }\end{array}$ & $\begin{array}{l}\text { Not applicable, since the separation of chairman and CEO } \\
\text { is built into the structure of two-tier boards. }\end{array}$ \\
\hline $\begin{array}{l}\text { (5) Cooling-off period for the } \\
\text { CEO (chairman of the } \\
\text { management board) to } \\
\text { become chairman of the } \\
\text { supervisory board (COOL) }\end{array}$ & $\begin{array}{l}\text { Measured on a scale from } 0 \text { to } 1 \text { and shall be: } 20 \\
\text { (a) } 1 \text { if the CEO should not go on to be chairman of the } \\
\text { supervisory board for a period of at least five years after } \\
\text { the end of his/her tenure as CEO; } \\
\text { (b) } 0.7 \text { if the waiting period is at least three, but less than } \\
\text { five, years; } \\
\text { (c) } 0.4 \text { if the waiting period is at least one, but less than } \\
\text { three, years; } \\
\text { (d) } 0 \text { otherwise. }\end{array}$ \\
\hline
\end{tabular}

${ }_{19}$ This panel applies to the following countries: Austria, Germany, Hungary, Netherlands, Poland, Slovakia, and Slovenia. See below Appendix B, Table B.1.

${ }^{20}$ The values are based on the realistic assumption that the first year is more important than the following years in addressing potential conflicts of interest. 


(6) Structures to mitigate
conflicts of interest (CON)
(a) Appointments to the board
(b) Responsibility for internal
control and appointment of
the external auditor
(c) Remuneration decisions

(a) Appointments to the management board: the variable is measured on a scale from 0 to 1 and shall be:

(i) 1 if the code requires that a nomination committee is set up within the supervisory board to make the appointment decision or prepare the appointment decision of the supervisory board and that the committee is composed of a majority of independent members of the supervisory board;

(ii) 0.5 if the code requires that a nomination committee is set up within the supervisory board, but the code does not require a majority of the board members to be independent members of the supervisory board;

(iii) 0 if neither (i) nor (ii) are satisfied.

(b) Responsibility for internal control and appointment of the external auditor: the variable is measures on a scale from 0 to 1 and shall be:

(i) 1 if the code requires that an audit committee is set up within the supervisory board to monitor the integrity of the financial information provided by the company, review the internal control and risk management systems, decide on, or make recommendations with respect to, the selection, appointment, and removal of the external auditor, and monitor the external auditor; and further if the code requires that the committee is composed of a majority of independent members of the supervisory board;

(ii) 0.5 if the code requires that an audit committee is set up within the supervisory board, but the code does not require a majority of the board members to be independent members of the supervisory board;

(iii) 0 if neither (i) nor (ii) are satisfied.

(c) Remuneration decisions: the variable is measured on a scale from 0 to 1 and shall be:

(i) 1 if the code requires that a remuneration committee is set up within the supervisory board to determine the remuneration of the members of the management board or make proposals for the determination of remuneration and that the committee is composed of a majority of independent members of the supervisory board;

(ii) 0.5 if the code requires that a remuneration committee is set up within the supervisory board, but the code does not require a majority of the board members to be independent members of the supervisory board;

(iii) 0 if neither (i) nor (ii) are satisfied.

The total value for 'Structures to mitigate conflicts of interest' is the average of the above components, provided that they are applicable. 
Appendix B: Coding of the board structure variable

Table B.1: Distinction between executive and non-executive directors (EXD)

\begin{tabular}{|c|c|c|c|c|}
\hline Country & Value & $\begin{array}{l}\text { Adjustment } \\
\text { Factor }(\%)\end{array}$ & $\begin{array}{l}\text { Total } \\
\text { value }\end{array}$ & Code provision \\
\hline $\begin{array}{l}\text { †Austria } \\
2009 \\
2002\end{array}$ & $\begin{array}{l}\mathrm{n} / \mathrm{a} \\
\mathrm{n} / \mathrm{a}\end{array}$ & & & \\
\hline $\begin{array}{l}\text { †Belgium } \\
2009 \\
2004 \\
1998 E^{21} \\
1998 C^{22}\end{array}$ & $\begin{array}{l}1 \\
1 \\
0 \\
1\end{array}$ & $\begin{array}{l}100 \\
100 \\
- \\
100\end{array}$ & $\begin{array}{l}1 \\
1 \\
0 \\
1\end{array}$ & $\begin{array}{l}2.3 \\
2.2 \\
1.3,2.2 \\
\text { I.B.1.4 }\end{array}$ \\
\hline $\begin{array}{l}\ddagger \text { 的ulgaria } \\
2007\end{array}$ & 0 & - & 0 & 3.2 \\
\hline $\begin{array}{l}* \text { Cyprus } \\
2002 \\
\end{array}$ & 0.5 & 100 & 0.5 & A.2.1 \\
\hline $\begin{array}{l}\text { †Denmark } \\
2010 \\
2003\end{array}$ & $\begin{array}{l}123 \\
124 \\
\end{array}$ & $\begin{array}{l}100 \\
100\end{array}$ & $\begin{array}{l}1 \\
1\end{array}$ & $\begin{array}{l}\text { Companies Act, } \int 111(1)(a) \\
\text { V.4 }\end{array}$ \\
\hline $\begin{array}{l}\text { †Finland } \\
2008 \\
2003\end{array}$ & $\begin{array}{l}1 \\
1\end{array}$ & $\begin{array}{l}100 \\
100\end{array}$ & $\begin{array}{l}1 \\
1\end{array}$ & $\begin{array}{l}14,15 \\
17,18\end{array}$ \\
\hline $\begin{array}{l}\ddagger \text { France } \\
2011^{25} \\
2010^{26} \\
2003^{27} \\
1998^{28} \\
1995^{29}\end{array}$ & $\begin{array}{l}0.5^{30} \\
1 \\
1 \\
0.5^{31} \\
0.5^{32} \\
\end{array}$ & $\begin{array}{l}100 \\
75^{33} \\
75^{34} \\
100 \\
100 \\
\end{array}$ & $\begin{array}{l}0.5 \\
0.75 \\
0.75 \\
0.5 \\
0.5 \\
\end{array}$ & $\begin{array}{l}\text { II.B.1 } \\
6.3,8.2 \\
6.3,8.2 \\
\text { II.B.1 } \\
\text { II.2 } \\
\end{array}$ \\
\hline
\end{tabular}

${ }^{21}$ Author: Federation of Belgian Enterprises (VBO/FEB).

22 Cardon Report, prepared by the Belgian Corporate Governance Committee - Commission Bancaire et Financiere.

${ }^{23}$ Danish company law requires the majority of the members of the supervisory board to be non-executive directors, see Jesper L. Hansen, The Danish Green Paper on Company Law Reform - Modernising Company Law in the 21st Century, 10 EBOR 73, 87 (2009); Report on Corporate Governance in Denmark of 2003, p. 16.

${ }^{24}$ See $\mathrm{n} 23$.

${ }^{25}$ Author: Association Française de la Gestion Financière (AFG-ASFFI).

26 Author: Association Française des Entreprises Privées (AFEP), Mouvement des Entreprises de France (MEDEF).

27 Author: as the code of 2010 (n 26).

28 Author: AFG.

${ }^{29}$ Vienot I Report. The Vienot commission was set up by the French Employers' Association CNPF (Conseil National du Patronat Français) and AFEP.

30 The code does not contain a separate provision regarding the balance between executive and non-executive directors, but requires one third of the board to be comprised of independent directors. Since independence encompasses the requirement that the director should not be an officer of the corporation, I assign the value of 0.5. Code de Commerce, Art. L225-53, provides that the number of executive directors (directeurs généraux délégués) shall not exceed five. Given that the number of directors on the board of the public company (sociéte anonyme) shall range between 3 and 18 (Art. L225-17), the statute does not necessarily require a greater proportion of non-executive directors than the code.

${ }^{31}$ See n 30 .

32 The code does not contain a separate provision regarding the balance between executive and non-executive directors, but restrictions are derived from statute, see n 30 above. 


\begin{tabular}{|c|c|c|c|c|}
\hline $\begin{array}{l}\text { †Germany } \\
2010^{35} \\
2002^{36} \\
2000 B^{37} \\
2000^{38}\end{array}$ & $\begin{array}{l}\mathrm{n} / \mathrm{a} \\
\mathrm{n} / \mathrm{a} \\
\mathrm{n} / \mathrm{a} \\
\mathrm{n} / \mathrm{a}\end{array}$ & & & \\
\hline $\begin{array}{l}* \text { Greece } \\
2011^{39} \\
200140 \\
199941\end{array}$ & $\begin{array}{l}1 \\
0 \\
1\end{array}$ & $\begin{array}{l}75^{42} \\
- \\
100\end{array}$ & $\begin{array}{l}0.75 \\
0 \\
1\end{array}$ & $\begin{array}{l}\text { A.II. } 2.2 \\
\text { B.2.1 } \\
5.6\end{array}$ \\
\hline $\begin{array}{l}\ddagger \text { Hungary } \\
2004\end{array}$ & $\mathrm{n} / \mathrm{a}$ & & & \\
\hline $\begin{array}{l}\text { †Italy } \\
2011 \\
199943\end{array}$ & $\begin{array}{l}0 \\
0\end{array}$ & $\begin{array}{l}- \\
-\end{array}$ & $\begin{array}{l}0 \\
0\end{array}$ & $\begin{array}{l}2 . P .3 \\
2.1\end{array}$ \\
\hline $\begin{array}{l}\ddagger \text { Luxemb. } \\
2006\end{array}$ & 0 & - & 0 & 3.3 \\
\hline $\begin{array}{l}* \text { Malta } \\
2001\end{array}$ & 0 & - & 0 & 2.3 \\
\hline $\begin{array}{l}\text { fNetherl. } \\
2008 \\
2003 \\
\end{array}$ & $\begin{array}{l}\mathrm{n} / \mathrm{a} \\
\mathrm{n} / \mathrm{a}\end{array}$ & & & \\
\hline $\begin{array}{l}\text { *Norway } \\
2010 \\
2004\end{array}$ & $\begin{array}{l}1 \\
1\end{array}$ & $\begin{array}{l}100 \\
100\end{array}$ & $\begin{array}{l}1 \\
1\end{array}$ & $\begin{array}{l}8 \\
8\end{array}$ \\
\hline $\begin{array}{l}\text { †Poland } \\
2010 \\
2002 G^{44} \\
2002 C^{45} \\
\end{array}$ & $\begin{array}{l}\mathrm{n} / \mathrm{a} \\
\mathrm{n} / \mathrm{a} \\
\mathrm{n} / \mathrm{a}\end{array}$ & & & \\
\hline $\begin{array}{l}\ddagger \text { Portugal } \\
2010 \\
1999\end{array}$ & $\begin{array}{l}0.5^{46} \\
0\end{array}$ & $\begin{array}{l}100 \\
-\end{array}$ & $\begin{array}{l}0.5 \\
0\end{array}$ & $\begin{array}{l}\text { II.1.2.1 } \\
14\end{array}$ \\
\hline $\begin{array}{l}\text { †lovakia } \\
2008\end{array}$ & $\mathrm{n} / \mathrm{a}$ & & & \\
\hline
\end{tabular}

33 The code does not contain a separate provision regarding the balance between executive and non-executive directors, but requires half of the board to be comprised of independent directors in widely held companies without controlling shareholders, and one third in other corporations. Accordingly, I assign the value of 1, but adjust by 75 percent to take account of the fact that the correct value for companies without dispersed shareholders is 0.5 .

34 See $n 33$.

35 German Corporate Governance Code, prepared by the Government Commission on the German Corporate Governance Code.

${ }^{36}$ Cromme Code, prepared by the Government Commission (n 35).

${ }_{37}$ German Code of Corporate Governance, prepared by the Berlin Initiative Group (Berliner Initiativkreis).

${ }_{38}$ Corporate Governance Rules for German Quoted Companies, prepared by the German Panel on Corporate Governance.

39 Author: Hellenic Federation of Enterprises (SEV).

40 Author: same as n 39.

${ }^{41}$ Author: Committee on Corporate Governance in Greece, set up by the Capital Market Commission.

42 The code allows smaller companies (as defined in Annex I) to have less than half the board comprised of nonexecutive directors.

43 Preda Code.

${ }^{44}$ Gdańsk Code.

45 Polish Corporate Governance Forum

${ }^{46}$ The code does not specify a minimum number of non-executive directors, but it requires that at least one fourth of the board is composed of independent directors. According to the Portuguese Company Act, Art. 414-A(1)(b), independence means that the director must not exercise management functions within the company. 


\begin{tabular}{|c|c|c|c|c|}
\hline $\begin{array}{l}\text { ‡Slovenia } \\
2009 \\
2004\end{array}$ & $\begin{array}{l}\mathrm{n} / \mathrm{a} \\
\mathrm{n} / \mathrm{a}\end{array}$ & & & \\
\hline $\begin{array}{l}\text { *Spain } \\
2006 \\
2004 \\
2003\end{array}$ & $\begin{array}{l}1 \\
0.5^{47} \\
1\end{array}$ & $\begin{array}{l}100 \\
100 \\
100\end{array}$ & $\begin{array}{l}1 \\
0.5 \\
1\end{array}$ & $\begin{array}{l}\text { II.10 } \\
\text { I.3 } \\
\text { IV.3 }\end{array}$ \\
\hline $\begin{array}{l}\text { *Sweden } \\
2010 \\
2001\end{array}$ & $\begin{array}{l}1 \\
1\end{array}$ & $\begin{array}{l}100 \\
100\end{array}$ & $\begin{array}{l}1 \\
1\end{array}$ & $\begin{array}{l}\text { III. } 4.3 \\
3.1\end{array}$ \\
\hline $\begin{array}{l}\text { †Switzerl. } \\
2007 \\
2002 \\
\end{array}$ & $\begin{array}{l}1 \\
1 \\
\end{array}$ & $\begin{array}{l}100 \\
100 \\
\end{array}$ & $\begin{array}{l}1 \\
1 \\
\end{array}$ & $\begin{array}{l}12 \\
12 \\
\end{array}$ \\
\hline $\begin{array}{l}* \mathrm{UK} \\
2010^{48} \\
2003^{49} \\
1998^{50} \\
1992^{51}\end{array}$ & $\begin{array}{l}1 \\
1 \\
0.5 \\
0\end{array}$ & $\begin{array}{l}75^{52} \\
75^{53} \\
100 \\
-\end{array}$ & $\begin{array}{l}0.75 \\
0.75 \\
0.5 \\
0\end{array}$ & $\begin{array}{l}\text { B. } 1.2 \\
\text { A.3.2 } \\
3.14 \\
1.3\end{array}$ \\
\hline
\end{tabular}

*denotes countries with a unitary board system.

tdenotes countries with a dual board system for public companies.

łdenotes countries that offer a choice between the unitary and dual board systems. In this case, the assessment is based on the unitary board system (with the exception of the Netherlands, where the dual system is mandatory for large companies (structuur vennootschappen), Hungary, where the unitary board system has only recently been introduced (2006) and has no tradition in Hungarian company law, and Slovenia, where the majority of companies opt for the two-tier system). In Switzerland, board structure is formally based on the one-tier model, but corporate law is so flexible that corporations can structure (and many corporations have, in fact, structured) the board in a way that resembles the German two-tier model. ${ }^{54} \mathrm{We}$ use the definitions of the board structure variable applicable to the one-tier board. The Danish model is also a hybrid form that distinguishes between the (supervisory) board and the executive board (management). However, the two boards are not as clearly separated as, for example, in the German system, and the supervisory board may be

\footnotetext{
47 The code does not provide for a minimum proportion of non-executive directors, but at least one third of the board members must be independent. Independence requires that the director does not perform executive functions (see Code Provision I.4).

48 UK Corporate Governance Code, published by the Financial Reporting Council (FRC).

${ }^{49}$ Combined Code on Corporate Governance, based on the Higgs Report and Smith Report and published by the Financial Reporting Council (FRC).

${ }^{50}$ Principles of Corporate Governance based on the Hampel Report.

${ }^{51}$ Code of Best Practice proposed by the Cadbury Report. The coding is not based on the Report itself, but on the Code of Best Practice derived from the Report, since the code is the part of the Report to which the comply-or-explain principle applies (see para. 3.7 of the Report). It should be noted that the Report is in several respects more shareholder-friendly than the code.

${ }^{52}$ The code allows smaller companies (defined as companies below the FTSE 350) to have less than half the board comprised of non-executive directors.

53 See n 52.

${ }^{54}$ Swiss Code of Obligations (Obligationenrecht), Arts. 707-726.
} 
composed of both executive and non-executive members. ${ }^{55}$ We therefore use the definitions of the board structure variable applicable to the one-tier board.

55 On the Danish system see Jesper L. Hansen, The New Danish Companies Act of 2009, 11 EBOR 87 (2010); Hansen, n 23 above. 
Table B.2. Quantitative measure of independence of non-executive directors/members of the supervisory board (NO_IND)

\begin{tabular}{|c|c|c|c|c|}
\hline Country & Value & $\begin{array}{l}\text { Adjustment } \\
\text { Factor }(\%)\end{array}$ & $\begin{array}{l}\text { Total } \\
\text { value }\end{array}$ & Code provision \\
\hline $\begin{array}{l}\text { Austria } \\
2009 \\
2002\end{array}$ & $\begin{array}{l}1 \\
1\end{array}$ & $\begin{array}{l}100 \\
50^{56}\end{array}$ & $\begin{array}{l}1 \\
0.5\end{array}$ & $\begin{array}{l}53 \\
52-55\end{array}$ \\
\hline $\begin{array}{l}\text { Belgium } \\
2009 \\
2004 \\
1998 \mathrm{E} \\
1998 \mathrm{C}\end{array}$ & $\begin{array}{l}0.5 \\
0.5 \\
0 \\
0\end{array}$ & $\begin{array}{l}100 \\
100 \\
- \\
-\end{array}$ & $\begin{array}{l}0.5 \\
0.5 \\
0 \\
0\end{array}$ & $\begin{array}{l}\text { 2.3: at least three members } \\
2.2 \text { : at least three members } \\
2.2 \\
\text { I.B. } 2.2\end{array}$ \\
\hline $\begin{array}{l}\text { Bulgaria } \\
2007\end{array}$ & 0 & - & 0 & 3.2 \\
\hline $\begin{array}{l}\text { Cyprus } \\
2002\end{array}$ & 1 & 100 & 1 & A. 2.2 \\
\hline $\begin{array}{l}\text { Denmark } \\
2010 \\
2003\end{array}$ & $\begin{array}{l}157 \\
1^{58}\end{array}$ & $\begin{array}{l}100 \\
100\end{array}$ & $\begin{array}{l}1 \\
1\end{array}$ & $\begin{array}{l}5.4 .1 \\
\text { V.4 }\end{array}$ \\
\hline $\begin{array}{l}\text { Finland } \\
2008 \\
2003\end{array}$ & $\begin{array}{l}1 \\
1\end{array}$ & $\begin{array}{l}100 \\
100\end{array}$ & $\begin{array}{l}1 \\
1\end{array}$ & $\begin{array}{l}14 \\
17\end{array}$ \\
\hline $\begin{array}{l}\text { France } \\
2011 \\
2010 \\
2003 \\
1998 \\
1995\end{array}$ & $\begin{array}{l}0.5 \\
1 \\
1 \\
0.5 \\
0.5\end{array}$ & $\begin{array}{l}100 \\
75^{59} \\
75^{60} \\
100 \\
100\end{array}$ & $\begin{array}{l}0.5 \\
0.75 \\
0.75 \\
0.5 \\
0.5 \\
\end{array}$ & $\begin{array}{l}\text { II.B.1 } \\
8.2 \\
8.2 \\
\text { II.B.1 } \\
\text { II.2: at least two members } \\
\end{array}$ \\
\hline $\begin{array}{l}\text { Germany } \\
2010 \\
2002 \\
2000 B \\
2000\end{array}$ & $\begin{array}{l}0 \\
0 \\
0 \\
0\end{array}$ & $\begin{array}{l}- \\
- \\
-\end{array}$ & $\begin{array}{l}0 \\
0 \\
0 \\
0\end{array}$ & $\begin{array}{l}\text { 5.4.2: adequate number of ind. } \\
\text { Directors } \\
\text { 5.4.1 } \\
\text { No mention of independence. } \\
\text { III.1(b): sufficient number of ind. } \\
\text { directors }\end{array}$ \\
\hline
\end{tabular}

${ }^{56}$ Quantitative independence requirements relate only to particular types of relation of the director with the company (see, e.g., 52: 'To ensure the independence of the advisory and monitoring tasks of the supervisory board, not more than two former members of the management board or senior management may be appointed to the supervisory board.').

57 The code requires half of the members elected by the general meeting to be independent. Since independence means that the board member is a non-executive director, the requirement of NO_IND(a) is satisfied that a majority of the non-executive directors should be independent (members not elected by the general meeting are not considered).

${ }^{58}$ The code requires a majority of the members elected by the general meeting to be independent. Since independence means that the board member is a non-executive director, the requirement of NO_IND(a) is satisfied that a majority of the non-executive directors should be independent (members not elected by the general meeting are not considered). 59 The code requires half of the members of the board to be independent in widely held corporations without controlling shareholders and one third in other corporations. Since independence means that the board member is a non-executive director, the requirement of NO_IND(a) that a majority of the non-executive directors should be independent is satisfied for widely held corporations. However, it is not necessarily satisfied for companies with controlling shareholders. I therefore adjust by 75 percent.

${ }^{60}$ See n 59 . 


\begin{tabular}{|c|c|c|c|c|}
\hline $\begin{array}{l}\text { Greece } \\
2011 \\
2001 \\
1999\end{array}$ & $\begin{array}{l}1 \\
0 \\
0\end{array}$ & $\begin{array}{l}100 \\
- \\
-\end{array}$ & $\begin{array}{l}1 \\
0 \\
0\end{array}$ & $\begin{array}{l}\text { A.II.2.3 } \\
\text { B.2.3 } \\
6.2\end{array}$ \\
\hline $\begin{array}{l}\text { Hungary } \\
2004\end{array}$ & 1 & 100 & 1 & 1.5 .5 \\
\hline $\begin{array}{l}\text { Italy } \\
2011 \\
1999\end{array}$ & $\begin{array}{l}0.5 \\
0\end{array}$ & $\begin{array}{l}- \\
-\end{array}$ & $\begin{array}{l}0.5 \\
0\end{array}$ & $\begin{array}{l}\text { 3.C.3: at least two members } \\
3\end{array}$ \\
\hline $\begin{array}{l}\text { Luxemb. } \\
2006\end{array}$ & 0 & - & 0 & 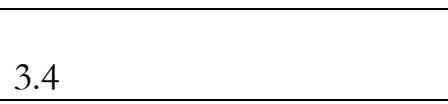 \\
\hline $\begin{array}{l}\text { Malta } \\
2001\end{array}$ & $1^{61}$ & 100 & 1 & 2.5 \\
\hline $\begin{array}{l}\text { Netherl. } \\
2008 \\
2003\end{array}$ & $\begin{array}{l}1 \\
1\end{array}$ & $\begin{array}{l}100 \\
100\end{array}$ & $\begin{array}{l}1 \\
1\end{array}$ & $\begin{array}{l}\text { III.2.1 } \\
\text { III.2.1 }\end{array}$ \\
\hline $\begin{array}{l}\text { Norway } \\
2010 \\
2004 \\
\end{array}$ & $\begin{array}{l}1 \\
0.5\end{array}$ & $\begin{array}{l}100 \\
100\end{array}$ & $\begin{array}{l}1 \\
0.5\end{array}$ & $\begin{array}{l}8 \\
\text { 8: one-half }\end{array}$ \\
\hline $\begin{array}{l}\text { Poland } \\
2010 \\
2002 \mathrm{G} \\
2002 \mathrm{C}\end{array}$ & $\begin{array}{l}0.5 \\
0.5 \\
0.5\end{array}$ & $\begin{array}{l}100 \\
100 \\
100\end{array}$ & $\begin{array}{l}0.5 \\
0.5 \\
0.5\end{array}$ & $\begin{array}{l}\text { III.6: at least two members } \\
\text { II.1: at least two members } \\
\text { 20(a): one-half }\end{array}$ \\
\hline $\begin{array}{l}\text { Portugal } \\
2010 \\
1999\end{array}$ & $\begin{array}{l}0.5 \\
0.5\end{array}$ & $\begin{array}{l}100 \\
2562\end{array}$ & $\begin{array}{l}0.5 \\
0.125\end{array}$ & $\begin{array}{l}\text { II.1.2..2: one-fourth } \\
\text { 15: at least one member }\end{array}$ \\
\hline $\begin{array}{l}\text { Slovakia } \\
2008\end{array}$ & 1 & $50^{63}$ & 0.5 & V.E.1 \\
\hline $\begin{array}{l}\text { Slovenia } \\
2009 \\
2004 \\
\end{array}$ & $\begin{array}{l}0.5 \\
1\end{array}$ & $\begin{array}{l}100 \\
100\end{array}$ & $\begin{array}{l}0.5 \\
1\end{array}$ & $\begin{array}{l}6.2 \\
3.3 .1\end{array}$ \\
\hline $\begin{array}{l}\text { Spain } \\
2006 \\
2004 \\
2003 \\
\end{array}$ & $\begin{array}{l}0.5 \\
1 \\
0.5^{64} \\
\end{array}$ & $\begin{array}{l}100 \\
75^{65} \\
100\end{array}$ & $\begin{array}{l}0.5 \\
0.75 \\
0.5 \\
\end{array}$ & $\begin{array}{l}\text { II.13 } \\
\text { I.3 } \\
\text { IV.3 } \\
\end{array}$ \\
\hline
\end{tabular}

${ }^{61}$ The code provides that '[n]on-executive Directors should be free from any business or other relationship, which could interfere materially with the exercise of their independent and impartial judgement.' See Code Provision 2.5. I interpret this provision as meaning that all non-executive directors should satisfy the independence requirements laid down in the code.

${ }^{62}$ Independence is understood not in the common sense of independent from management, but only from the dominant shareholders (see also DEF_IND) (although it is acknowledged that the dominant shareholders are likely to exert control over the company's operations; independence from them is, therefore, of particular importance in jurisdictions characterised by large blockholdings). In addition, the code's requirement ('one or more members') is not substantially different from the definition of NO_IND(c) (the code contains only general statements). Therefore, I adjust two times by the usual amount (50 percent).

${ }^{63}$ The binding principle only provides that the supervisory board 'should include independent members' and that the chairman 'should always be an independent person.' The requirement that a majority of the members of the supervisory board shall be independent is included in the Notes to Code Principle V.E.1. Since the notes are nonbinding (see Corporate Governance Code for Slovakia, p. 4), I apply an adjustment of 50 percent.

${ }^{64}$ The code speaks of 'a very significant number of independent directors', which I interpret as being more than merely a general statement within the meaning of NO_IND(c).

${ }^{65}$ The code requires only companies without a majority or controlling shareholder to have a majority of independent non-executive directors. For other companies, the number should not fall below one third of total board members. The provision is, therefore, between NO_IND(a) and (b). 


\begin{tabular}{|l|l|l|l|l|}
\hline Sweden & & 100 & 1 & III.4.4 \\
2010 & 1 & 100 & 1 & 3.1 \\
2001 & 1 & & & \\
\hline Switzerl. & & 0 & 12 \\
2007 & 0 & - & 0 & 12 \\
2002 & 0 & & & \\
\hline UK & & 100 & 1 & B.1.2 \\
2010 & 1 & 100 & 1 & A.3.2 \\
2003 & 1 & 100 & 1 & $2.5,3.9$ \\
1998 & 1 & 100 & 1 & 2.2 \\
1992 & 1 & & & \\
\hline
\end{tabular}




\section{Table B.3. Qualitative measure of independence of non-executive directors/members of the supervisory board (DEF_IND)}

\begin{tabular}{|c|c|c|c|c|}
\hline Country & Value & $\begin{array}{l}\text { Adjustment } \\
\text { Factor }(\%)\end{array}$ & $\begin{array}{l}\text { Total } \\
\text { value }\end{array}$ & Code provision \\
\hline $\begin{array}{l}\text { Austria } \\
2009 \\
2002\end{array}$ & $\begin{array}{l}0.3^{66} \\
0.2\end{array}$ & $\begin{array}{l}100 \\
100\end{array}$ & $\begin{array}{l}0.3 \\
0.2\end{array}$ & $\begin{array}{l}\text { 53, Annex } 1 \\
52,53,55^{67}\end{array}$ \\
\hline $\begin{array}{l}\text { Belgium } \\
2009 \\
2004 \\
1998 E \\
1998 C \\
\end{array}$ & $\begin{array}{l}1 \\
0.9 \\
0 \\
0.35 \\
\end{array}$ & $\begin{array}{l}100 \\
100 \\
- \\
50^{68}\end{array}$ & $\begin{array}{l}1 \\
0.9 \\
0 \\
0.3^{69}\end{array}$ & $\begin{array}{l}\text { Appendix A } \\
\text { Appendix A } \\
2.2 \\
\text { I.B.2.2 }\end{array}$ \\
\hline $\begin{array}{l}\text { Bulgaria } \\
2007\end{array}$ & 0.1 & $50^{70}$ & 0.05 & $\begin{array}{l}\text { 4.4: independent directors should not } \\
\text { receive any additional remuneration }\end{array}$ \\
\hline $\begin{array}{l}\text { Cyprus } \\
2002\end{array}$ & 0.3 & 100 & 0.3 & A.2.2 \\
\hline $\begin{array}{l}\text { Denmark } \\
2010 \\
2003\end{array}$ & $\begin{array}{l}1 \\
0.4^{71}\end{array}$ & $\begin{array}{l}100 \\
100\end{array}$ & $\begin{array}{l}1 \\
0.4\end{array}$ & $\begin{array}{l}5.4 .1 \\
\text { V.4 }\end{array}$ \\
\hline $\begin{array}{l}\text { Finland } \\
2008 \\
2003\end{array}$ & $\begin{array}{l}0.9 \\
0.6\end{array}$ & $\begin{array}{l}50 \text { for }(\mathrm{i}) \\
\text { and }(\mathrm{j})^{72} \\
50 \text { for }(\mathrm{j})^{73}\end{array}$ & $\begin{array}{l}0.8 \\
0.55\end{array}$ & $\begin{array}{l}15 \\
18\end{array}$ \\
\hline $\begin{array}{l}\text { France } \\
2011 \\
2010\end{array}$ & $\begin{array}{l}0.7 \\
0.9\end{array}$ & $\begin{array}{l}50 \text { for }(f)^{74} \\
50^{75}\end{array}$ & $\begin{array}{l}0.65 \\
0.45\end{array}$ & $\begin{array}{l}\text { II.B.1 } \\
8.3-8.5\end{array}$ \\
\hline
\end{tabular}

66 The code contains the general statement that independent supervisory board members should 'not have any business or personal relations with the company or its management board that constitute a material conflict of interests'. Annex 1 also contains a list of factors (six of which meet the benchmark of the Commission Recommendation) that indicate independence. However, these factors are merely guidelines (see Annex 1). Pursuant to Code Provision 53, the supervisory board has to define the criteria that constitute independence on the basis of the general clause and ' $[\mathrm{t}]$ he guidelines in Annex 1 shall serve as further orientation.' Therefore, I only assign the value for the general statement.

${ }_{67}$ Only code provision 52 ('not more than two former members of the management board or senior management may be appointed to the supervisory board') is binding. Code provisions 53 and 55 , which contain additional independence requirements (e.g. prohibition of cross-representation), are so-called R-rules, i.e. the rule 'is a recommendation; noncompliance ... requires neither disclosure nor explanation' (Code of 2002, p. 7).

${ }^{68} \mathrm{I}$ apply an adjustment of 50 percent because the independence criteria are only an expression of the view of the Belgian Commission on Corporate Governance (see Code Provision B.2.2: 'The Belgian Commission on Corporate Governance takes the view that a director may be considered independent if . .'). The ultimate decision whether a director is independent rests with the board: 'It is for the board to decide whether an independent director satisfies the definition of independence given below.'

${ }^{69}$ Since the score for DEF_IND is below 0.3 after the adjustment applied in $\mathrm{n} 68$, but the code also contains a general description of independence which warrants the value 0.3 according to our definition, I assign the latter.

${ }^{70}$ Adjustment factor is 50 because Code Provision 4.4 does not specify a period of time preceding the director's appointment during which he/she must not have received additional remuneration.

${ }^{71}$ Some of the independence criteria listed in the code do not fit well within DEF_IND, particularly that the director shall not have any 'essential strategic interest in the company other than that of a shareholder'. I relate this requirement to $\mathrm{DEF} \_\mathrm{IND}(\mathrm{f})$ and quantify the variable accordingly.

72 According to the Finnish code, criteria (i) and (j) (tenure not longer than 12 years and no close family connection) are not fixed requirements, but shall be taken into account by the board when it makes its overall evaluation of the director's independence, see Code Provision 15.

${ }^{73}$ See $\mathrm{n} 72$.

${ }^{74}$ Adjustment factor is 50 because the code does not specify a period of time preceding the director's appointment during which he/she must not have been a business partner of the company. 


\begin{tabular}{|c|c|c|c|c|}
\hline $\begin{array}{l}2003 \\
1998 \\
1995 \\
\end{array}$ & $\begin{array}{l}0.9 \\
0.45 \\
0.4\end{array}$ & $\begin{array}{l}50^{76} \\
100 \\
100\end{array}$ & $\begin{array}{l}0.45 \\
0.45 \\
0.4 \\
\end{array}$ & $\begin{array}{l}8.3-8.5 \\
\text { II.B.1 } \\
\text { II.2, II.4 }\end{array}$ \\
\hline $\begin{array}{l}\text { Germany } \\
2010 \\
2002 \\
2000 B \\
2000 \\
\end{array}$ & $\begin{array}{l}0.3 \\
0.3 \\
0 \\
0.3 \\
\end{array}$ & $\begin{array}{l}100 \\
100 \\
- \\
100\end{array}$ & $\begin{array}{l}0.3 \\
0.3 \\
0 \\
0.3 \\
\end{array}$ & $\begin{array}{l}5.4 .2 \\
5.4 .2 \\
\text { No mention of independence. } \\
\text { III.1(b) }\end{array}$ \\
\hline $\begin{array}{l}\text { Greece } \\
2011 \\
2001 \\
1999\end{array}$ & $\begin{array}{l}0.8 \\
0.1^{177} \\
0.3\end{array}$ & $\begin{array}{l}100 \\
100 \\
100\end{array}$ & $\begin{array}{l}0.8 \\
0.1 \\
0.3\end{array}$ & $\begin{array}{l}\text { A.II.2.5 } \\
\text { B.2.3 } \\
6.3\end{array}$ \\
\hline $\begin{array}{l}\text { Hungary } \\
2004\end{array}$ & 0.3 & 100 & 0.3 & 1.5.5 \\
\hline $\begin{array}{l}\text { Italy } \\
2011 \\
1999\end{array}$ & $\begin{array}{l}0.8 \\
0.2\end{array}$ & $\begin{array}{l}50^{78} \\
100\end{array}$ & $\begin{array}{l}0.4 \\
0.2\end{array}$ & $\begin{array}{l}3 . C .1 \\
3\end{array}$ \\
\hline $\begin{array}{l}\text { Luxemb. } \\
2006\end{array}$ & $0.3^{79}$ & 100 & 0.3 & 3.5, Appendix D \\
\hline $\begin{array}{l}\text { Malta } \\
2001\end{array}$ & 0.3 & 100 & 0.3 & 2.6 \\
\hline $\begin{array}{l}\text { Netherl. } \\
2008 \\
2003\end{array}$ & $\begin{array}{l}0.7 \\
0.7\end{array}$ & $\begin{array}{l}100 \\
100\end{array}$ & $\begin{array}{l}0.7 \\
0.7\end{array}$ & $\begin{array}{l}\text { III. } 2.2 \\
\text { III. } 2.2\end{array}$ \\
\hline $\begin{array}{l}\text { Norway } \\
2010 \\
2004\end{array}$ & $\begin{array}{l}0.7 \\
0.7\end{array}$ & $\begin{array}{l}100 \\
100\end{array}$ & $\begin{array}{l}0.7 \\
0.7\end{array}$ & $\begin{array}{l}8 \\
8\end{array}$ \\
\hline $\begin{array}{l}\text { Poland } \\
2010 \\
2002 G \\
2002 C\end{array}$ & $\begin{array}{l}1 \\
0.3 \\
0.3\end{array}$ & $\begin{array}{l}100 \\
100 \\
100\end{array}$ & $\begin{array}{l}1 \\
0.3 \\
0.3\end{array}$ & $\begin{array}{l}\text { III.6 } \\
\text { II.2 } \\
20(\text { a) }\end{array}$ \\
\hline $\begin{array}{l}\text { Portugal } \\
2010\end{array}$ & $0.5^{80}$ & 100 & 0.5 & II.1.2.3 \\
\hline
\end{tabular}

${ }^{75} \mathrm{I}$ apply an adjustment of 50 percent because the board, in judging independence, 'may consider that, although a particular director meets all of the above criteria, he or she cannot be held to be independent owing to the specific circumstances of the person or the company, due to its ownership structure or for any other reason. Conversely, the Board may consider that a director who does not meet the above criteria is nevertheless an independent director.' See Code Provision 8.3. Hence, the board has some discretion that may be used to dilute the independence criteria.

${ }^{76}$ Code Provision 8.3 contains a provision similar to that reproduced in $\mathrm{n} 75$.

77 Independence is only defined with regard to shareholders.

${ }^{78}$ The list of independence criteria is not binding on the board of directors when it evaluates the independence of the board's non-executive members, but serves merely as an example. Code Provision 3.C.1 provides that the board should have 'regard more to the contents than to the form and [keep] in mind that a director usually does not appear independent in the following events [the list of criteria], to be considered merely as an example'. Further, the Comment makes it clear that the board 'may adopt, for the purpose of its evaluations, additional or different, in whole or in part, criteria from those mentioned [in Code Provision 3.C.1]. However, the board must also give 'adequate information to the market together with the relevant reasons' (Comment to Art. 3). Therefore, transparency is at least partly ensured. ${ }^{79}$ The Luxembourg code reproduces the independence criteria of the Commission Recommendation in Appendix D, but the appendix is not binding. The code stipulates that 'the company may make use of the independence criteria appearing in Annex II of the European Commission Recommendation of 15 February 2005' (emphasis by author). Only the general formulation in Code Provision 3.5 is binding. 


\begin{tabular}{|c|c|c|c|c|}
\hline 1999 & 0.181 & 100 & 0.1 & 15 \\
\hline $\begin{array}{l}\text { Slovakia } \\
2008\end{array}$ & 0.85 & $\begin{array}{l}50 \text { for all } \\
\text { and } \\
\text { another } 50 \\
\text { for }(d)^{82}\end{array}$ & 0.4 & V.E.2 \\
\hline $\begin{array}{l}\text { Slovenia } \\
2009 \\
2004\end{array}$ & $\begin{array}{l}1 \\
0.3\end{array}$ & $\begin{array}{l}100 \\
100\end{array}$ & $\begin{array}{l}1 \\
0.3\end{array}$ & $\begin{array}{l}\text { 6.2, 8, 17, Appendix C } \\
3.3 .1,3.5 .4\end{array}$ \\
\hline $\begin{array}{l}\text { Spain } \\
2006 \\
2004 \\
2003\end{array}$ & $\begin{array}{l}0.9 \\
1 \\
0.3\end{array}$ & $\begin{array}{l}100 \\
100 \\
100\end{array}$ & $\begin{array}{l}0.9 \\
1 \\
0.3\end{array}$ & $\begin{array}{l}\text { III.5 } \\
\text { I.4 } \\
\text { IV.2.1(c) }\end{array}$ \\
\hline $\begin{array}{l}\text { Sweden } \\
2010 \\
2001\end{array}$ & $\begin{array}{l}0.9^{83} \\
0^{84}\end{array}$ & $\begin{array}{l}50 \text { for }(d)^{85} \\
50 \text { for }(e)^{86}\end{array}$ & $\begin{array}{l}0.8 \\
0\end{array}$ & $\begin{array}{l}\text { III.4.4, } 4.5 \\
3.1\end{array}$ \\
\hline $\begin{array}{l}\text { Switzerl. } \\
2007 \\
2002\end{array}$ & $\begin{array}{l}0.3 \\
0.3\end{array}$ & $\begin{array}{l}100 \\
100\end{array}$ & $\begin{array}{l}0.3 \\
0.3\end{array}$ & $\begin{array}{l}22 \text { (applies only to committee } \\
\text { composition) } \\
22 \text { (applies only to committee } \\
\text { composition) }\end{array}$ \\
\hline $\begin{array}{l}\text { UK } \\
2010 \\
2003\end{array}$ & $\begin{array}{l}0.9^{87} \\
0.9^{88}\end{array}$ & $\begin{array}{l}75^{89} \\
75^{90}\end{array}$ & $\begin{array}{l}0.675 \\
0.675\end{array}$ & $\begin{array}{l}\text { B.1.1 } \\
\text { A.3.1 }\end{array}$ \\
\hline
\end{tabular}

${ }^{80}$ Code Provision II.1.2.3 stipulates that, in assessing independence, the board of directors 'shall take into account the legal and regulatory rules in force concerning the independency requirements and the incompatibility framework applicable to members of other corporate boards', which refers to Arts. 414, 414-A of the Portuguese Commercial Company Act. The Code Provision continues: 'An independent executive member shall not be considered as such, if in another corporate board and by force of applicable rules, may not be an independent executive member.' Thus, the code incorporates the statutory independence requirements. Our assessment takes this into consideration.

${ }^{81}$ Independence is only defined with regard to the dominant shareholders.

82 The adjustment of 50 percent for (d) results from the fact that the code does not specify a period of time preceding the director's appointment during which he/she must not have received additional remuneration. The overall adjustment of 50 percent is justified because the criteria for independence are contained in the non-binding notes to the Code Principle, while the Principle itself advances only general statements.

83 The code only requires independent directors not to have been CEO of the company within the last five years; it does not establish the general rule that former executive directors cannot be considered as independent (as opposed to the definition in DEF_IND(a), (b)). However, in Swedish companies no more than one member of the board may be an executive director, and this member is generally the CEO, see Swedish Corporate Governance Code, p. 11.

${ }^{84}$ Independence is only defined with regard to the company's employees, and even in that respect the code does not set a minimum time limit, as envisaged in DEF_IND(a)-(c).

85 Adjustment factor is 50 because Code Provision 4.4 does not specify a period of time preceding the director's appointment during which he/she must not have received additional remuneration.

${ }^{86}$ Code Provision 4.5 requires that at least two members of the board have to be independent of the company's major shareholders, in addition to satisfying the independence requirements of Code Provision 4.4. I therefore adjust the value for DEF_IND(e) by 50 percent.

${ }^{87}$ In contrast to the Commission Recommendation, Annex II(1)(a) and (b), the UK Corporate Governance Code does not contain separate provisions requiring independent directors not to have been executive directors and not to have been employees. The UK Code merely provides that the independent director must not have been an employee of the company within the last five years, see Code Provision B.1.1. However, since executive directors are employees, the UK Code addresses both factors listed separately by the Commission Recommendation. Therefore, I understand the UK provision as satisfying DEF_IND(a)-(c).

88 Same as $\mathrm{n} 87$.

${ }^{89}$ B.1.1 provides that ' $[\mathrm{t}]$ he board should determine whether the director is independent in character and judgement and whether there are relationships or circumstances which are likely to affect, or could appear to affect, the director's judgement. The board should state its reasons if it determines that a director is independent notwithstanding the 


\begin{tabular}{|l|l|l|l|l|}
\hline 1998 & 0.3 & 100 & 0.3 & 3.9 \\
1992 & 0.3 & 100 & 0.3 & 2.2 \\
\hline
\end{tabular}

existence of relationships or circumstances which may appear relevant to its determination, including [the factors corresponding to the definition of DEF_IND].' This means that the board can determine that it acts in compliance with the independence requirements even though a director does not satisfy all of the criteria that the code considers to be relevant for the determination of independence. As a consequence, the directors would be technically in full compliance with the Code and did not have to provide an explanation for non-compliance, see David Kershaw, Company Law in Context (2nd ed., OUP 2012), p. 258. However, since the Code Provision itself requires the directors to state their reasons and since transparency is, therefore, ensured, I only apply an adjustment of 25 percent. In the case of the Italian Code 2011, the adjustment is larger (50 percent, see $n 78$ above), because the requirement to give reasons for not following the list of criteria is not enshrined in the Code Provisions, but only mentioned in the official comment to the rule (Comment to Art. 3 Italian Corporate Governance Code 2011). The same applies to France (see $\mathrm{n}$ 75,76 above).

${ }^{90}$ Same as n 89 . 
Table B.4. Separation of chairman and CEO (SEP)

\begin{tabular}{|c|c|c|c|c|}
\hline Country & Value & $\begin{array}{l}\text { Adjustment } \\
\text { Factor }(\%)\end{array}$ & $\begin{array}{l}\text { Total } \\
\text { value }\end{array}$ & Code provision \\
\hline $\begin{array}{l}\text { Austria } \\
2009 \\
2002\end{array}$ & $\begin{array}{l}\mathrm{n} / \mathrm{a} \\
\mathrm{n} / \mathrm{a}\end{array}$ & & & \\
\hline $\begin{array}{l}\text { Belgium } \\
2009 \\
2004 \\
1998 \mathrm{E} \\
1998 \mathrm{C} \\
\end{array}$ & $\begin{array}{l}1 \\
1 \\
0 \\
0\end{array}$ & $\begin{array}{l}100 \\
100 \\
- \\
-\end{array}$ & $\begin{array}{l}1 \\
1 \\
0 \\
0\end{array}$ & $\begin{array}{l}1.5 \\
1.5 \\
1.2 \\
\text { I.B.1.3 } \\
\end{array}$ \\
\hline $\begin{array}{l}\text { Bulgaria } \\
2007\end{array}$ & 1 & 100 & 1 & 3.3 \\
\hline $\begin{array}{l}\text { Cyprus } \\
2002\end{array}$ & 1 & $75^{91}$ & 0.75 & A.2.4 \\
\hline $\begin{array}{l}\text { Denmark } \\
2010 \\
2003\end{array}$ & $\begin{array}{l}1 \\
1\end{array}$ & $\begin{array}{l}100^{92} \\
50^{93}\end{array}$ & $\begin{array}{l}1 \\
0.5\end{array}$ & $\begin{array}{l}4.3 .4 \\
-\end{array}$ \\
\hline $\begin{array}{l}\text { Finland } \\
2008 \\
2003 \\
\end{array}$ & $\begin{array}{l}1 \\
1 \\
\end{array}$ & $\begin{array}{l}100 \\
100 \\
\end{array}$ & $\begin{array}{l}1 \\
1 \\
\end{array}$ & $\begin{array}{l}36 \\
40 \\
\end{array}$ \\
\hline $\begin{array}{l}\text { France } \\
2011 \\
2010 \\
2003 \\
1998\end{array}$ & $\begin{array}{l}1 \\
0 \\
0 \\
1\end{array}$ & $\begin{array}{l}75^{94} \\
- \\
- \\
5095 \\
\end{array}$ & $\begin{array}{l}0.75 \\
0 \\
0 \\
0.5 \\
\end{array}$ & $\begin{array}{l}\text { II.A.3 } \\
3.1-3.2 \\
3.1-3.2 \\
\text { II.A.3 }\end{array}$ \\
\hline
\end{tabular}

${ }^{91}$ The code requires that there 'should be a clear division of responsibility in the positions of Chairman of the Board of Directors and Chief Executive Officer'. The provision continues: 'In the event that these positions are not separate, this should be justified in part two of the report.' This is comparable to the provision of the UK Corporate Governance Code described above in $\mathrm{n} 89$, which allows for deviations from the corporate governance rules but ensures transparency.

92 The Danish Companies Act, $\ 114$, stipulates that the chairman of the board is not entitled to exercise such powers on behalf of the company as are not a natural part of the office of chairman of the board, apart from individual tasks which the person concerned is requested to perform by and for the board of directors (see Hansen, n 23 above, 87; Report on Corporate Governance in Denmark of 2003, p. 16). The corporate governance code further specifies that the chairman may, 'in exceptional cases [...] briefly participate in the day-to-day management' of the corporation. However, the performance of management duties requires a board resolution and the disclosure of any agreements regarding the chairman's participation in the company's management. Arguably, the brief participation in the day-today management does not jeopardise the general separation of CEO and chairman of the board as required by the Companies Act. It is therefore justified not to adjust the value of 1 .

93 The rule derives from Danish company legislation, see n 92 above. As opposed to the 2010 Code discussed in n 92 , the 2003 Code does not contain additional restrictions, disclosure obligations, or procedural requirements to be followed when the chairman is entrusted with management powers. In order to take account of the lower level of regulation in the 2003 Code, an adjustment of 50 percent is applied.

${ }^{94}$ The code holds that 'AFG is in favour of the general principle of separation of functions, namely executive and control power, through a separation of the function of chairperson of the board from that of the chief executive officer, or through a supervisory and management board's structure'. However, the code also acknowledges that companies, 'as an exception, [may] decide not to implement such a separation of functions'. In spite of this ambiguity in the code provision, only an adjustment of 25 percent is applied for the following reasons: First, the Code Provision itself requires the company to explain the decision to the shareholders. The transparency envisaged by corporate governance codes is, therefore, ensured (see n 89 above for a similar argument). Second, the code requires that if the two functions are not separated a lead independent director shall be appointed who has power to monitor the board, add items to the board agenda, and convene the board if necessary.

${ }^{95}$ An adjustment factor of 50 percent is used because the code does not require the separation of CEO and chairman unambiguously. Code Provision A.3 merely provides that 'AFG-ASFI invites companies to deliberate on [...] the option 


\begin{tabular}{|l|l|l|l|l|}
\hline 1995 & 0 & - & 0 & I.4 \\
\hline $\begin{array}{l}\text { Germany } \\
2010\end{array}$ & $\mathrm{n} / \mathrm{a}$ & & & \\
2002 & $\mathrm{n} / \mathrm{a}$ & & \\
$2000 \mathrm{~B}$ & $\mathrm{n} / \mathrm{a}$ \\
2000 & $\mathrm{n} / \mathrm{a}$ & & & \\
\hline $\begin{array}{l}\text { Greece } \\
2011\end{array}$ & 1 & 2596 & 0.25 & A.III.3.3 \\
2001 & 0 & - & 0 & - \\
1999 & 1 & $50^{97}$ & 0.5 & 5.5 \\
\hline $\begin{array}{l}\text { Hungary } \\
2004\end{array}$ & $\mathrm{n} / \mathrm{a}$ & & & \\
\hline $\begin{array}{l}\text { Italy } \\
2011\end{array}$ & 1 & $75^{98}$ & 0.75 & $2 . P .4,2 . P .5,2 . C .3,2 . C .4$ \\
1999 & 0 & - & 0 & $2.1,4.3$ (Comment) \\
\hline $\begin{array}{l}\text { Luxemb. } \\
2006\end{array}$ & 1 & 100 & 1 & 1.3 \\
\hline $\begin{array}{l}\text { Malta } \\
2001\end{array}$ & 1 & 7599 & 0.75 & 2.3 \\
\hline $\begin{array}{l}\text { Netherl. } \\
2008\end{array}$ & $\mathrm{n} / \mathrm{a}$ & & & \\
2003 & $\mathrm{n} / \mathrm{a}$ & & & \\
\hline $\begin{array}{l}\text { Norway } \\
2010\end{array}$ & 1 & 100 & 1 & 8 \\
2004 & 1 & 100 & 1 & \\
\hline $\begin{array}{l}\text { Poland } \\
2010\end{array}$ & $\mathrm{n} / \mathrm{a}$ & & & \\
$2002 \mathrm{G}$ & $\mathrm{n} / \mathrm{a}$ & & & \\
\hline
\end{tabular}

provided by the law on the separation of the functions of the Chairman of the Board and the Managing Director' and that 'AFG-ASFI is in favor of this separation in the interest of shareholders.' (Emphases by author.)

${ }^{96}$ Companies may combine the roles of chairman and CEO, but in that case, or where the former CEO has been appointed as chairman within three years of his retirement, the board must appoint an independent vice-chairman. The code specifies the competences of the vice-chairman. The vice-chairman has responsibility, inter alia, for the evaluation of the executive chairman (Code Provision 3.4). In light of these specific rules, it seems justified to use the value for $\operatorname{SEP}($ a), significantly adjusted. See also below n 100 for a comparable provision.

${ }^{97} \mathrm{I}$ use an adjustment factor of 50 percent because the code merely provides that ' $[\mathrm{t}] \mathrm{he}$ separation of duties and responsibilities in the highest levels of the corporation's governance should be encouraged (emphasis by author).

${ }_{98}$ The code does not require unambiguously that CEO and chairman are separated, it merely provides that "[i]t is appropriate to avoid the concentration of corporate offices in one single individual' (2.P.4). The code acknowledges that 'the existence of situations of accumulation of the two roles may satisfy, in particular in issuers of smaller size, valuable organizational requirements' (see Comment to Art. 2). However, the code also stipulates that if management powers have been delegated to the chairman, the board should disclose the reasons for this organisation choice in the corporate governance report (2.P.5). In addition, in this case the board shall designate an independent director as lead independent director (2.C.3), who 'represents a reference and coordination point for the requests and contributions of non-executive directors' (2.C.4). In light of these substitute mechanisms, it is appropriate to assign the Italian Code the value of 1 and apply an adjustment of 25 percent.

${ }^{99}$ The code is ambivalent in that it does not prohibit the combination of the roles of CEO and chairman, but merely stipulates that '[i]deally, the Chairman's role in leading the Board should be separate from that of the Chief Executive'. The provision is comparable to that in the Italian code of 2011 (see n 98 above) because it requires that if the roles of CEO and chairman are combined the company must provide an explanation to the market. Hence, the provision conforms to the transparency rationale of corporate governance codes. In addition, the code stresses that in such cases 'it is important that the nonexecutive Directors are of sufficient calibre to bring an independent judgement to bear on the various issues brought before' the board. Accordingly, the code requires that directors are appointed 'whose independence and standing would offer a balance to the strength of character of such a chairman'. 


\begin{tabular}{|l|l|l|l|l|}
\hline $2002 \mathrm{C}$ & $\mathrm{n} / \mathrm{a}$ & & & \\
\hline $\begin{array}{l}\text { Portugal } \\
2010\end{array}$ & 0 & - & 0 & II.2.3 \\
1999 & 0 & - & 0 & - \\
\hline $\begin{array}{l}\text { Slovakia } \\
2008\end{array}$ & $\mathrm{n} / \mathrm{a}$ & & & \\
\hline Slovenia & & & & \\
2009 & $\mathrm{n} / \mathrm{a}$ & & & \\
2004 & $\mathrm{n} / \mathrm{a}$ & & & \\
\hline Spain & & & & \\
2006 & 1 & 25100 & 0.25 & II.17 \\
2004 & 1 & 100 & 1 & I.2 \\
2003 & 0 & - & 0 & IV.4 \\
\hline Sweden & & 100 & 1 & \\
2010 & 1 & 100 & 1 & II.4, III.6.2 \\
2001 & 1 & & & 3.1 \\
\hline Switzerl. & & - & 0 & 18 \\
2007 & 0 & - & 0 & 18 \\
2002 & 0 & 100 & 1 & \\
\hline UK & 1 & 100 & 1 & A.2.1, A.3.1 \\
2010 & 1 & 75101 & 0.75 & 3.17 \\
2003 & 1 & - & 0 & 1.2 \\
1998 & 0 & & \\
1992 & & &
\end{tabular}

100 The code does not require the chairman and CEO to be separated, but where the two roles are exercised by the same person, an independent director shall be empowered to request the calling of board meetings and the inclusion of new business on the agenda in order to coordinate and give voice to the concerns of external directors, and lead the board's evaluation of the chairman (Code Provision 17). In light of this provision, it does not seem to be justified to assign the value of 0 to the Spanish Code. Rather, the value of 1 should be adjusted significantly to take into account the lack of formal separation on the one hand, but the introduction of a controlling element in the form of the senior lead independent director with specified powers. Consequently, I treat the provision as comparable to Greece 2011, discussed above $n$ 96. Note that the adjustment is higher than in the cases of France 1998 (n 95), Greece 1999 (n 97), Italy 2011 (n 98), and Malta 2001 (n 99), because, as opposed to these codes, the Spanish rule does not give any recommendation at all, not even one that is phrased ambiguously. Compare the other codes with the formulation of the Spanish provision: 'The concentration of powers can provide companies with clear internal and external leadership, while avoiding the information and coordination costs that would otherwise be generated. [...] [G]iven the divergence of international practice and the lack of empirical evidence for a precise recommendation, the Code makes no comment on the advisability or otherwise of separating the two positions.' See Comment before Code Provisions 16 and 17.

101 The same considerations as in $\mathrm{n} 91$ above apply. 
Table B.5. Cooling-off period for the CEO to become chairman of the (supervisory) board (COOL)

\begin{tabular}{|c|c|c|c|c|}
\hline Country & Value & $\begin{array}{l}\text { Adjustment } \\
\text { Factor }(\%)\end{array}$ & $\begin{array}{l}\text { Total } \\
\text { value }\end{array}$ & Code provision \\
\hline $\begin{array}{l}\text { Austria } \\
2009 \\
2002\end{array}$ & $\begin{array}{l}0.4 \\
0\end{array}$ & $\begin{array}{l}100 \\
-\end{array}$ & $\begin{array}{l}0.4 \\
0\end{array}$ & $\begin{array}{l}\text { 55: two years } \\
-\end{array}$ \\
\hline $\begin{array}{l}\text { Belgium } \\
2009 \\
2004 \\
1998 \mathrm{E} \\
1998 \mathrm{C} \\
\end{array}$ & $\begin{array}{l}0 \\
0 \\
0 \\
0 \\
\end{array}$ & $\begin{array}{l}- \\
- \\
- \\
-\end{array}$ & $\begin{array}{l}0 \\
0 \\
0 \\
0 \\
\end{array}$ & $\begin{array}{l}1.5 \\
1.5 \\
1.2 \\
\text { I.B.1.3 }\end{array}$ \\
\hline $\begin{array}{l}\text { Bulgaria } \\
2007\end{array}$ & 0 & - & 0 & 3.3 \\
\hline $\begin{array}{l}\text { Cyprus } \\
2002\end{array}$ & 0 & - & 0 & A.2.4 \\
\hline $\begin{array}{l}\text { Denmark } \\
2010 \\
2003\end{array}$ & $\begin{array}{l}0 \\
0\end{array}$ & - & $\begin{array}{l}0 \\
0\end{array}$ & $\begin{array}{l}4.3 .4 \\
-\end{array}$ \\
\hline $\begin{array}{l}\text { Finland } \\
2008 \\
2003\end{array}$ & $\begin{array}{l}0 \\
0\end{array}$ & $\begin{array}{l}- \\
-\end{array}$ & $\begin{array}{l}0 \\
0\end{array}$ & $\begin{array}{l}36 \\
40\end{array}$ \\
\hline $\begin{array}{l}\text { France } \\
2011 \\
2010 \\
2003 \\
1998 \\
1995\end{array}$ & $\begin{array}{l}0 \\
0 \\
0 \\
0 \\
0\end{array}$ & $\begin{array}{l}- \\
- \\
- \\
- \\
-\end{array}$ & $\begin{array}{l}0 \\
0 \\
0 \\
0 \\
0\end{array}$ & $\begin{array}{l}\text { II.A.3 } \\
3.1-3.2 \\
3.1-3.2 \\
\text { II.A.3 } \\
\text { I.4 } \\
\end{array}$ \\
\hline $\begin{array}{l}\text { Germany } \\
2010 \\
2002 \\
2000 B \\
2000 \\
\end{array}$ & $\begin{array}{l}0.4 \\
0 \\
0 \\
0 \\
\end{array}$ & $\begin{array}{l}50102 \\
- \\
- \\
- \\
\end{array}$ & $\begin{array}{l}0.2 \\
0 \\
0 \\
0 \\
\end{array}$ & $\begin{array}{l}\text { 5.4.4: two years } \\
5.4 \\
\text { IV.4.4 } \\
\text { III.1 }\end{array}$ \\
\hline $\begin{array}{l}\text { Greece } \\
2011 \\
2001 \\
1999 \\
\end{array}$ & $\begin{array}{l}0.7 \\
0 \\
0 \\
\end{array}$ & $\begin{array}{l}25^{103} \\
- \\
- \\
\end{array}$ & $\begin{array}{l}0.175 \\
0 \\
0 \\
\end{array}$ & $\begin{array}{l}\text { A.III.3.3: three years } \\
- \\
5.5\end{array}$ \\
\hline $\begin{array}{l}\text { Hungary } \\
2004\end{array}$ & 0 & - & 0 & $1.5 .4^{104}$ \\
\hline
\end{tabular}

102 Adjustment factor is 50 percent because code provision 5.4.4 stipulates that 'Management Board members may not become members of the Supervisory Board of the company within two years after the end of their appointment unless they are appointed upon a motion presented by shareholders holding more than $25 \%$ of the voting rights in the company. In the latter case appointment to the chairmanship of the Supervisory Board shall be an exception to be justified to the General Meeting.' This exception does not preserve transparency to the same extent as the comply-orexplain principle requires. The company is technically in compliance with the code when the CEO is appointed as chairman without waiting for two years. The supervisory board only has to give reasons to the general meeting, but it does not have to explain the deviation from the code in the next annual report. Therefore, outside investors cannot easily assess whether the cooling-off period was applied consistently or not.

103 The adjustment is justified for the same reasons as explained above $\mathrm{n} 96$. 


\begin{tabular}{|c|c|c|c|c|}
\hline $\begin{array}{l}\text { Italy } \\
2011 \\
1999\end{array}$ & $\begin{array}{l}0 \\
0\end{array}$ & - & $\begin{array}{l}0 \\
0\end{array}$ & $\begin{array}{l}\text { 2.P.4, 2.P.5, 2.C.3, 2.C.4 } \\
\text { 2.1, } 4.3 \text { (Comment) }\end{array}$ \\
\hline $\begin{array}{l}\text { Luxemb. } \\
2006\end{array}$ & 0 & - & 0 & 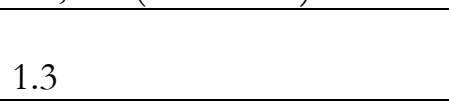 \\
\hline $\begin{array}{l}\text { Malta } \\
2001\end{array}$ & 0 & - & 0 & 2.3 \\
\hline $\begin{array}{l}\text { Netherl. } \\
2008 \\
2003\end{array}$ & $\begin{array}{l}1 \\
1\end{array}$ & $\begin{array}{l}100 \\
100\end{array}$ & $\begin{array}{l}1 \\
1\end{array}$ & $\begin{array}{l}\text { III.4.2: no former managers } \\
\text { III.4.2: no former managers }\end{array}$ \\
\hline $\begin{array}{l}\text { Norway } \\
2010 \\
2004 \\
\end{array}$ & $\begin{array}{l}0 \\
0 \\
\end{array}$ & - & $\begin{array}{l}0 \\
0\end{array}$ & $\begin{array}{l}8 \\
8 \\
\end{array}$ \\
\hline $\begin{array}{l}\text { Poland } \\
2010 \\
2002 G \\
2002 \mathrm{C}\end{array}$ & $\begin{array}{l}0 \\
0 \\
0\end{array}$ & $\begin{array}{l}- \\
- \\
-\end{array}$ & $\begin{array}{l}0 \\
0 \\
0\end{array}$ & $\begin{array}{l}- \\
- \\
-\end{array}$ \\
\hline $\begin{array}{l}\text { Portugal } \\
2010 \\
1999\end{array}$ & $\begin{array}{l}0 \\
0\end{array}$ & $\begin{array}{l}- \\
-\end{array}$ & $\begin{array}{l}0 \\
0\end{array}$ & $\begin{array}{l}\text { II.2.3 } \\
-\end{array}$ \\
\hline $\begin{array}{l}\text { Slovakia } \\
2008 \\
\end{array}$ & 1 & $50^{105}$ & 0.5 & V.E.1, V.E.2 \\
\hline $\begin{array}{l}\text { Slovenia } \\
2009 \\
2004\end{array}$ & $\begin{array}{l}0.4 \\
0\end{array}$ & $\begin{array}{l}100 \\
-\end{array}$ & $\begin{array}{l}0.4 \\
0\end{array}$ & $\begin{array}{l}10.1 \\
-\end{array}$ \\
\hline $\begin{array}{l}\text { Spain } \\
2006 \\
2004 \\
2003 \\
\end{array}$ & $\begin{array}{l}0 \\
0 \\
0 \\
\end{array}$ & $\begin{array}{l}- \\
- \\
-\end{array}$ & $\begin{array}{l}0 \\
0 \\
0 \\
\end{array}$ & $\begin{array}{l}\text { II.17 } \\
\text { I. } 2 \\
\text { IV.4 } \\
\end{array}$ \\
\hline $\begin{array}{l}\text { Sweden } \\
2010 \\
2001\end{array}$ & $\begin{array}{l}0^{106} \\
1\end{array}$ & - & $\begin{array}{l}0 \\
0.5 \\
\end{array}$ & $\begin{array}{l}\text { II.4, III.2.6, III.6.2 } \\
3.1\end{array}$ \\
\hline $\begin{array}{l}\text { Switzerl. } \\
2007 \\
2002\end{array}$ & $\begin{array}{l}0 \\
0\end{array}$ & - & $\begin{array}{l}0 \\
0\end{array}$ & $\begin{array}{l}18 \\
18\end{array}$ \\
\hline $\begin{array}{l}\text { UK } \\
2010 \\
2003 \\
1998 \\
1992 \\
\end{array}$ & $\begin{array}{l}1 \\
1 \\
0 \\
0\end{array}$ & $\begin{array}{l}100 \\
100 \\
- \\
-\end{array}$ & $\begin{array}{l}1 \\
1 \\
0 \\
0\end{array}$ & $\begin{array}{l}\text { A.2.1, A.3.1 } \\
\text { A.2.1, A. } 2.2 \\
3.17 \\
1.2\end{array}$ \\
\hline
\end{tabular}

${ }^{104}$ Referring to the chairman of the board of directors (not the supervisory board) and the CEO.

${ }^{105}$ Code Principle V.E.1 requires that the chairman of the supervisory board must be independent. As part of the independence criteria, the code stipulates that the director should not have been a member of the company's management in the last five years. However, the independence criteria are contained in the non-binding notes to Code Principle V.E.2, which is why an adjustment of 50 percent is applied.

${ }^{106}$ Code Provision III.2.6 only provides that '[i]f the outgoing chief executive officer is nominated for the post of chair, reasons for this proposal are [...] to be fully explained.'

107 The code does not lay down a waiting period or stipulate that the CEO should never go on to become chairman of the board, it merely provides that '[a] Managing Director who is leaving that position should normally not be appointed as Chairman or remain on the board'. Because of this ambivalence the value is adjusted by 50 percent. 
Table B.6. Structures to mitigate conflicts of interest (CON)

\begin{tabular}{|c|c|c|c|c|}
\hline$\overline{\text { Country }}$ & Value & $\begin{array}{l}\text { Adjustment } \\
\text { Factor }(\%)\end{array}$ & Total value & Code provision \\
\hline $\begin{array}{l}\text { Austria } \\
2009 \\
2002\end{array}$ & $\begin{array}{l}\text { (a): } 1 ;(b): \\
1 ;(c): 1^{108} \\
\text { (a): } 0.5 ; \\
\text { (b): } 0.5 ; \\
\text { (c): } 0.5\end{array}$ & $\begin{array}{l}100 \\
100\end{array}$ & $\begin{array}{l}1 \\
0.5\end{array}$ & $\begin{array}{l}\text { Nomination: } 39 \text {, } 41 \text {; audit: } 39-40 \text {; } \\
\text { remuneration: } 39 \text {, } 43 \\
\text { Nomination: } 43 \text {; audit: } 40-41 \text {; } \\
\text { remuneration: } 43\end{array}$ \\
\hline $\begin{array}{l}\text { Belgium } \\
2009 \\
2004 \\
1998 \mathrm{E} \\
1998 \mathrm{C}\end{array}$ & $\begin{array}{l}\text { (a): } 1 ; \text { (b): } \\
\text { 1; (c): } 1 \\
\text { (a): } 1 ; \text { (b): } \\
\text { 1; (c): } 1 \\
\text { (a): } 0 ; \text { (b): } \\
0 ; \text { (c): } 0.5 \\
\text { (a): } 0.5 ; \\
\text { (b): } 1 ; \text { (c): } \\
0.5\end{array}$ & $\begin{array}{l}100 \\
100 \\
50 \text { for (c) }{ }^{109} \\
50 \text { for (a) } \\
\text { and (c) })^{110}\end{array}$ & $\begin{array}{l}1 \\
1 \\
0.25 / 3=0.08 \\
(0.25+1+ \\
0.25) / 3=0.5\end{array}$ & $\begin{array}{l}\text { Nomination: Appendix D; audit: } \\
\text { Appendix C; remuneration: } \\
\text { Appendix E } \\
\text { Nomination: Appendix D; audit: } \\
\text { Appendix C; remuneration: } \\
\text { Appendix E } \\
\text { Nomination:2.3; audit: } 4.3 \text {; } \\
\text { remuneration: } 3.1 \\
\text { Nomination:I.B.2.4; audit: I.B.4.3; } \\
\text { remuneration: I.B.3.2 }\end{array}$ \\
\hline $\begin{array}{l}\text { Bulgaria } \\
2007\end{array}$ & $\begin{array}{l}\text { (a): } 0 ;(b): \\
1 ;(c): 0\end{array}$ & $\begin{array}{l}50 \text { for } \\
\text { (b) }{ }^{111}\end{array}$ & $0.5 / 3=0.17$ & 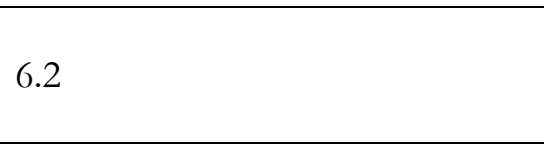 \\
\hline $\begin{array}{l}\text { Cyprus } \\
2002\end{array}$ & $\begin{array}{l}\text { (a): } 0.5 ; 112 \\
\text { (b): } 1 ; \text { (c): } \\
1\end{array}$ & $\begin{array}{l}50 \text { for } \\
\text { (b) }\end{array}$ & $\begin{array}{l}(0.5+0.5+1) / 3 \\
=0.67\end{array}$ & $\begin{array}{l}\text { Nomination: A.4.1; audit: C.3.1; } \\
\text { remuneration: B.1.1, B1.2 }\end{array}$ \\
\hline $\begin{array}{l}\text { Denmark } \\
2010 \\
2003\end{array}$ & $\begin{array}{l}\text { (a): } 1 ;(b): \\
1 ;(c): 1 \\
0\end{array}$ & 100 & 1 & $\begin{array}{l}5.10 \\
\text { Nomination: V.10; audit: V.10, } \\
\text { VIII.7 ; remuneration: V.10 }\end{array}$ \\
\hline $\begin{array}{l}\text { Finland } \\
2008\end{array}$ & (a): 1; (b): & 100 & 1 & Nomination: 28-30; audit: 24-27; \\
\hline
\end{tabular}

108 (a), (b), and (c) refer to board appointments, responsibility for internal control and appointment of the external auditor, and remuneration, respectively.

109 The code does not require a remuneration committee to be established, but if the company sets up such a committee, it must be composed exclusively of non-executive directors. Furthermore, the code provides that, if no remuneration committee is established, the remuneration of executive directors should be submitted to the nonexecutive directors (3.1). Therefore, it seems justified to give some credit to the code for these provisions.

${ }^{110}$ The code does not require a nomination or remuneration committee to be established, but if the company sets up such committees, the code stipulates how they should be composed (similar to $\mathrm{n} 109$ ).

111 The code does not specify the responsibilities of the audit committee. Accordingly, it is relatively easy to compromise the effectiveness of the provision by defining the audit committee's duties restrictively. See the flexibility granted by Code Provision 6.3 .

112 A majority of the members of the nomination committee should be non-executive directors, but the code does not require independence.

${ }^{113}$ The code requires the audit committee to be composed of a majority of independent non-executive directors, but the audit committee is only responsible for preparing a decision on the appointment, dismissal and remuneration of the external auditor (Code Provision C.3.2). The audit committee's remit does not include reviewing the company's internal control systems (pursuant to Code Provision C.2.1, this is the responsibility of the board of directors). 


\begin{tabular}{|c|c|c|c|c|}
\hline 2003 & $\begin{array}{l}1 ;(\mathrm{c}): 1 \\
\text { (a): } 0.5 ; \\
\text { (b): } 1 ;(\mathrm{c}): \\
0.5\end{array}$ & 100 & $\begin{array}{l}(0.5+1+0.5) / 3 \\
=0.67\end{array}$ & $\begin{array}{l}\text { remuneration: } 31-33 \\
\text { Nomination: } 31-33 \text {; audit: 27-30; } \\
\text { remuneration: } 34-36\end{array}$ \\
\hline $\begin{array}{l}\text { France } \\
2011 \\
2010 \\
2003 \\
1998 \\
1995\end{array}$ & $\begin{array}{l}\text { (a): } 0.5 ; \\
\text { (b): } 0.5 ; \\
\text { (c): } 1 \\
\text { (a): } 1 ; \text { (b): } \\
1 ; \text { (c): } 1 \\
\text { (a): } 1 ; \text { (b): } \\
1 ; \text { (c): } 1 \\
\text { (a): } 0.5 ; \\
\text { (b): } 0.5 ; \\
\text { (c): } 1 \\
\text { (a): } 0.5 ; \\
\text { (b): } 0.5 ; \\
\text { (c): } 0.5\end{array}$ & $\begin{array}{l}100 \\
100 \\
100 \\
50 \text { for } \\
(b)^{114} \\
100\end{array}$ & $\begin{array}{l}(0.5+0.5+1) / 3 \\
=0.67 \\
1 \\
1 \\
(0.5+0.25+1) \\
/ 3=0.58 \\
0.5\end{array}$ & $\begin{array}{l}\text { II.B.2 } \\
\text { Nomination: 15; audit: 14; } \\
\text { remuneration: } 16 \\
\text { Nomination: } 16 \text {; audit: 14; } \\
\text { remuneration: } 15 \\
\text { II.B.2 } \\
\text { Nomination: II.5; audit: III.3; } \\
\text { remuneration: III.3 }\end{array}$ \\
\hline $\begin{array}{l}\text { Germany } \\
2010 \\
2002 \\
2000 B \\
2000\end{array}$ & $\begin{array}{l}\text { (a): } 0.5 ; \\
\text { (b): } 0.5 ; \\
\text { (c): } 0 \\
\text { (a): } 0 ;(b): \\
0.5 ;(c): 0 \\
\text { (a): } 0.5 ; \\
\text { (b): } 0.5 ; \\
\text { (c): } 0.5 \\
\text { (a): } 0.5 ; \\
\text { (b): } 0.5 ; \\
\text { (c): } 0.5\end{array}$ & $\begin{array}{l}100 \\
100 \\
50 \text { for } \\
\text { (b) }{ }^{115} \\
50 \text { for all }\end{array}$ & $\begin{array}{l}(0.5+0.5) \\
/ 3=0.33 \\
0.5 / 3=0.17 \\
(0.5+0.25 \\
+0.5) / 3=0.42 \\
0.25\end{array}$ & $\begin{array}{l}5.3 \\
5.1 .2,5.3 \\
\text { IV.3.4 } \\
\text { III.3 }\end{array}$ \\
\hline $\begin{array}{l}\text { Greece } \\
2011 \\
2001 \\
1999\end{array}$ & $\begin{array}{l}\text { (a): } 0.5 ; \\
\text { (b): } 1 ;(c): \\
1 \\
\text { (a): } 0 \text {; (b): } \\
0.5 ;(c): \\
0.5 \\
\text { (a): } 0 \text {; (b): } \\
0.5 ;(c): \\
0.5\end{array}$ & $\begin{array}{l}100 \\
50 \text { for } \\
\text { (b) }{ }^{117} \\
50 \text { for } \\
\text { (b) }{ }^{118}\end{array}$ & $\begin{array}{l}(0.5+1+1) / 3 \\
=0.83 \\
(0.25+0.5) / 3 \\
=0.25 \\
(0.25+0.5) / 3 \\
=0.25\end{array}$ & $\begin{array}{l}\text { Nomination: A.V.5.4, 5.5; audit: } \\
\text { B.I.1.4; remuneration: C.I.1.6-1.9 } \\
\text { Nomination: -; audit: E.5.2; } \\
\text { remuneration: E.5.3 } \\
\text { Nomination: -; audit: 4.7; } \\
\text { remuneration: } 7.2\end{array}$ \\
\hline
\end{tabular}

114 The code does not specify the responsibilities of the audit committee.

115 The code does not specify the responsibilities of the audit committee.

116 The code does not require the establishment of committees of the supervisory board unambiguously; it stipulates that '[i]ncorproation and duties of committees are subject to the specific circumstances and the size of the Company' and then lists a number of committees (among them the audit committee and personnel committee, responsible for succession planning with regard to the management board and compensation of the management board members) that 'could be instituted'.

117 The competences of the audit committee (called 'Internal Control Committee'), as specified in Code Provision E.5.2, are limited.

${ }^{118}$ I use an adjustment factor of 50 percent because the code merely provides that ' $[\mathrm{t}]$ he establishment of an Internal Audit Committee should be encouraged (emphasis by author). 


\begin{tabular}{|c|c|c|c|c|}
\hline $\begin{array}{l}\text { Hungary } \\
2004\end{array}$ & $\begin{array}{l}\text { (a): } 1 ;(b): \\
1 ;(c): 1\end{array}$ & 100 & 1 & $\begin{array}{l}\text { Nomination: } 1.8 .3 \text {; audit: } 1.8 .2 \text {; } \\
\text { remuneration: } 1.8 .4\end{array}$ \\
\hline $\begin{array}{l}\text { Italy } \\
2011 \\
1999\end{array}$ & $\begin{array}{l}\text { (a): 1; (b): } \\
1 ; 119 \text { (c): } 1 \\
\text { (a): } 0.5 ; \\
\text { (b): } 0.5 ; \\
\text { (c): } 0.5\end{array}$ & $\begin{array}{l}75 \text { for all }{ }^{120} \\
50 \text { for }(a)^{121}\end{array}$ & $\begin{array}{l}0.75 \\
(0.25+0.5+ \\
0.5) / 3=0.42\end{array}$ & $\begin{array}{l}\text { Nomination: } 5 . P .1 \text {; audit: } 7 . P .4 \text {; } \\
\text { remuneration: } 6 . P .3 \\
\text { Nomination: } 7.2 \text {; audit: } 10.1 \text {; } \\
\text { remuneration: } 8.1\end{array}$ \\
\hline $\begin{array}{l}\text { Luxemb. } \\
2006\end{array}$ & $\begin{array}{l}\text { (a): } 0.5 ; 122 \\
\text { (b): } 0.5 ; 123 \\
\text { (c): } 0.5^{124}\end{array}$ & 100 & 0.5 & $\begin{array}{l}\text { Nomination: } 4.2-4.6 \text {; audit: 9.1-9.13; } \\
\text { remuneration: 8.1-8.7 }\end{array}$ \\
\hline $\begin{array}{l}\text { Malta } \\
2001\end{array}$ & $\begin{array}{l}\text { (a): } 1 ;(b): \\
1 ;(c): 1^{125}\end{array}$ & $\begin{array}{l}50 \text { for (a), } \\
75 \text { for (b) } \\
\text { and (c) }{ }^{126}\end{array}$ & $\begin{array}{l}(0.5+0.75+ \\
0.75) / 3=0.67\end{array}$ & $\begin{array}{l}\text { Nomination: } 2.10 \text {; audit: } 6 \text {; } \\
\text { remuneration: } 8\end{array}$ \\
\hline $\begin{array}{l}\text { Netherl. } \\
2008\end{array}$ & (a): 1; (b): & $100^{127}$ & 1 & III. 5 \\
\hline
\end{tabular}

${ }^{119}$ This value refers to the control and risk committee because the board of statutory auditors, which performs some of the functions of a traditional audit committee, has to be established pursuant to the Civil Code. The external auditor is appointed by shareholder resolution upon proposal of the board of auditors (Art. 13 of Legislative Decree 27 January 2010, no. 39). See also Mads Andenas and Frank Wooldridge, European Comparative Company Law (CUP 2009), pp. 324-330.

${ }_{120} \mathrm{I}$ apply an adjustment because the committee structure is not binding. However, pursuant to Code Provision 4.C.2, the board is only entitled to refrain from establishing one of the three committees if at least half of the board members are independent directors and the board describes the reasons for not forming one or more committees in detail in the corporate governance report. In light of these restrictions, an adjustment of less than 50 percent seems to be appropriate.

${ }^{121}$ The Code does not require the establishment of a nomination committee, but if such a committee is established, it should be composed of a majority of non-executive directors. Accordingly, I treat this code provision in the same way as those analysed above n 109, 110.

122 The rule that the nomination committee should be composed of a majority of independent directors is only contained in a non-binding guideline, see Code Provision 4.3. The 'comply or explain' principle does not apply to guidelines (Code of 2006, p. 7).

123 Same as n 122 .

124 Same as n 122 .

125 The code is ambivalent in that it requires that a majority of the members of the nomination and audit committees should be non-executive directors (Code Provisions 2.10, 6.1), whereas the remuneration committee 'should be composed of a majority of independent non-executive Directors with no personal financial interest other than as shareholders in the Company' (Code Provision 8.2). Since all non-executive directors should be independent (Code Provision 2.5), I interpret these requirements as meaning that a majority of the members of the nomination and audit committees should be independent non-executive directors, and that the members of the remuneration committee are subject to higher independence requirements, as stipulated in Code Provision 8.2 ('no personal financial interest').

126 I use an adjustment factor of 50 percent for (a) (nomination) because the code does not require the establishment of a nomination committee unambiguously. Code Provision 2.10 merely provides that the use of Nomination Committees is encouraged'. The Code is also ambiguous with respect to the other two committees, but it makes it clear that the establishment of such committees is expected. See Code Provision 6.1: 'It is good practice for the Board to create and maintain an Audit Committee [...]'. Code Provision 8.1 begins with the vague statement that ' $[\mathrm{t}]$ he use of Remuneration Committees by Listed Companies is to be positively considered.' But it continues more strongly by requiring that 'Boards of Directors should establish Remuneration Committees' (emphases by author). Therefore, I apply an adjustment factor of 75 percent regarding the latter two committees.

127 The requirement to establish the three committees is only mandatory if the supervisory board consists of more than four members. Since this is often the case, and the code applies most of the provisions that regulate the best practice of committees to the supervisory board if it does not establish one or more committees, it is appropriate not to adjust the value of 1 . 


\begin{tabular}{|c|c|c|c|c|}
\hline 2003 & $\begin{array}{l}\text { 1;(c): } 1 \\
\text { (a): } 1 ; \text { (b): } \\
1 ;(\mathrm{c}): 1\end{array}$ & $100^{128}$ & 1 & III.5 \\
\hline $\begin{array}{l}\text { Norway } \\
2010 \\
2004\end{array}$ & $\begin{array}{l}\text { (a): } 1 ; \text { (b): } \\
1 ;(\mathrm{c}): 1 \\
\text { (a): } 1 ; \text { (b): } \\
1 ;(\mathrm{c}): 1\end{array}$ & $\begin{array}{l}100^{129} \\
50 \text { for }(b) \\
\text { and }(c))^{130}\end{array}$ & $\begin{array}{l}1 \\
(1+0.5+ \\
0.5) / 3=0.67\end{array}$ & $\begin{array}{l}\text { Nomination: 7; audit: 9; } \\
\text { remuneration: } 9 \\
\text { Nomination: 7; audit: 9; } \\
\text { remuneration: } 9\end{array}$ \\
\hline $\begin{array}{l}\text { Poland } \\
2010 \\
2002 G \\
2002 C\end{array}$ & $\begin{array}{l}\text { (a): 1; (b): } \\
1 ;(\mathrm{c}): 1 \\
\text { (a): } 0 ;(\text { b): } \\
0.5 ;(\mathrm{c}): 0 \\
\text { (a): } 0 \text {; (b): } \\
0.5 ; \text { (c): } \\
0.5\end{array}$ & $\begin{array}{l}100 \\
50 \text { for } \\
\text { (b) })^{131} \\
50 \text { for (b) } \\
\text { and (c) }{ }^{132}\end{array}$ & $\begin{array}{l}1 \\
0.25 / 3=0.08 \\
(0.25+0.25) / 3 \\
=0.17\end{array}$ & $\begin{array}{l}\text { III.8 } \\
\text { Audit: VII } \\
\text { Audit and remuneration: } 20 \text { (c) }\end{array}$ \\
\hline $\begin{array}{l}\text { Portugal } \\
2010 \\
1999\end{array}$ & $\begin{array}{l}\text { (a): } 0 ;(b): \\
-133 ;(c): 1 \\
\text { (a): } 0.5 ; \\
\text { (b):-; (c): } \\
0.5\end{array}$ & $\begin{array}{l}100 \\
50 \text { for all }{ }^{134}\end{array}$ & $\begin{array}{l}(0+1) / 2=0.5 \\
(0.25+0.25) \\
/ 2=0.25\end{array}$ & $\begin{array}{l}\text { II. } 5 \\
17\end{array}$ \\
\hline
\end{tabular}

128 See $n 127$ above.

129 The Public Companies Act requires large companies to set up an audit committee. In smaller companies, the entire board of directors may act as the company's audit committee. The corporate governance code does not require smaller companies to establish an audit committee either, but merely states that such companies 'should give consideration to establishing an audit committee'. Likewise, the code is non-committal with regard to the remuneration committee. It provides that the board of directors 'should also consider appointing a remuneration committee'. On the other hand, in Norwegian companies the board of directors often does not contain any executive directors. If it does, the corporate governance code is stricter. Code Provision 8 states that the board should employ the use of committees, and the commentary to Code Provision 9 requires that ' $\mathrm{i}$ ] f any member of the executive personnel is a member of the board, an audit committee and a remuneration committee should be established in order to ensure the greatest possible independence for the board's deliberations'. I therefore do not perform any adjustment. Finally, it should be noted that the duties of the audit committee, while not specified in the code, are laid down in the Public Companies Act.

${ }^{130}$ Similar considerations as in $\mathrm{n} 129$ apply. Code Provision 9 stipulates that the board 'should consider appointing board committees'. Code Provision 8 requires the use of board committees where the board includes executive directors. However, the 2004 code is more lenient than the one from 2010 in only requiring the establishment of audit and remuneration committees where the chief executive is a member of the board (the 2010 code spoke of 'any member of the executive personnel'. Therefore, I adjust by 75 percent for the audit and remuneration committees.

131 The code does not require the establishment of an audit committee. I did, however, assign the value 0.5 , adjusted by a factor of 50 percent, in order to take account of the fact that the code provides that the auditor should be appointed by the supervisory board and that the relevant resolution of the board should require a yes vote of at least two independent board members. This ensures that the independent elements on the board have at least some say in the appointment decision.

${ }_{132}$ The code does not require the establishment of an audit or remuneration committee. I did, however, assign the value 0.5 with regard to these two committees, adjusted by a factor of 50 percent, in order to take account of the fact that the code provides that at least one independent member of the supervisory board has to give his/her consent when resolutions are adopted concerning "performances of any kind by the company $[\ldots]$ in favor of members of the management board' (i.e., also the determination of the directors' remuneration) and the appointment of the external auditor (Code Provision 20(c)).

${ }^{133}$ In the unitary board model, the audit committee must be established by law, which also stipulates the composition of the committee, see Portuguese Commercial Company Act, Art. 423-B. The audit committee is therefore not considered and the total value of $\mathrm{CON}$ is computed by dividing by 2 .

134 The code does not require the establishment of committees unambiguously. It merely provides that ' $\mathrm{t}]$ he board is encouraged to create internal control committees with powers conferred for matters in which there are potential situations of conflict of interests, such as the nomination of directors and managers, the analysis of the remuneration policy and assessment of the corporate structure and governance'. I therefore adjust by 50 percent. 


\begin{tabular}{|c|c|c|c|c|}
\hline $\begin{array}{l}\text { Slovakia } \\
2008\end{array}$ & $\begin{array}{l}\text { (a): } 1 ;(b): \\
1 ;(c): 1\end{array}$ & 75 for all 135 & $\begin{array}{l}(0.75+0.75+ \\
0.75) / 3=0.75\end{array}$ & $\begin{array}{l}\text { Nomination: V.E.4.A; audit: V.E.4.C; } \\
\text { remuneration: V.E.4.B }\end{array}$ \\
\hline $\begin{array}{l}\text { Slovenia } \\
2009 \\
2004\end{array}$ & $\begin{array}{l}\text { (a): } 0.5 \text {; } \\
\text { (b): } 1 ; \text { (c): } \\
0.5 \\
\text { (a): } 0.5 ; \\
\text { (b): } 1 ; \text { (c): } \\
0.5\end{array}$ & $\begin{array}{l}100 \\
50 \text { for all }\end{array}$ & $\begin{array}{l}(0.5+1+0.5) \\
/ 3=0.67 \\
(0.25+0.5+ \\
0.25) / 3=0.33\end{array}$ & $\begin{array}{l}\text { Nomination: } 13 \text {, Appendix B.3; } \\
\text { audit:13, App. B.1; remuneration: } 13 \text {, } \\
\text { App. B.2 } \\
\text { Nomination: } 3.2 .2 \text {, 3.8; audit: } 3.7 \text {; } \\
\text { remuneration: } 3.8\end{array}$ \\
\hline $\begin{array}{l}\text { Spain } \\
2006 \\
\\
2004 \\
2003\end{array}$ & $\begin{array}{l}\text { (a): } 1 ; \text { (b): } \\
0.5 ; 137 \text { (c): } \\
0.5 \\
\text { (a): } 1 ; \text { (b): } \\
1 ;(c): 0.5 \\
\text { (a): } 0.5 ; \\
\text { (b): } 0.5 ; \\
\text { (c): } 0.5\end{array}$ & $\begin{array}{l}100 \\
100 \\
100\end{array}$ & $\begin{array}{l}0.67 \\
(1+1+0.5) / 3 \\
=0.83 \\
0.5\end{array}$ & $\begin{array}{l}\text { Nomination: I.8; audit: I.11; } \\
\text { remuneration: I.9 } \\
\text { Nomination: IV.5.3; audit: IV.5.2; } \\
\text { remuneration: IV.5.3 }\end{array}$ \\
\hline $\begin{array}{l}\text { Sweden } \\
2010 \\
2001\end{array}$ & $\begin{array}{l}\text { (a): } 1 ;(b): \\
1 ;(c): 1 \\
\text { (a): } 0.5 \\
\text { (b): } 0.5 \\
\text { (c): } 0.5\end{array}$ & $\begin{array}{l}50 \text { for }(b) \\
\text { and }(c)^{138} \\
100\end{array}$ & $\begin{array}{l}(1+0.5+0.5) / 3 \\
=0.67 \\
0.5\end{array}$ & $\begin{array}{l}\text { Nomination: III.2; audit: III.7.3; } \\
\text { remuneration: III.9 } \\
\text { Nomination: 3.1.1; audit: 5.1; } \\
\text { remuneration: 3.1.1,139 4.1.2 }\end{array}$ \\
\hline $\begin{array}{l}\text { Switzerl. } \\
2007 \\
2002\end{array}$ & $\begin{array}{l}\text { (a): } 0.5 \text {; } \\
\text { (b): } 1 ;(\mathrm{c}): \\
1\end{array}$ & $\begin{array}{l}75 \text { for } \\
\text { (b) }{ }^{140}\end{array}$ & $\begin{array}{l}(0.5+0.75 \\
+1) / 3=0.75 \\
(0.5+0.75\end{array}$ & $\begin{array}{l}\text { Nomination: } 27 \text {; audit: } 23 \text {; } \\
\text { remuneration: } 25\end{array}$ \\
\hline
\end{tabular}

${ }^{135} \mathrm{I}$ use an adjustment factor of 75 percent because the code provides that the functions of the three committees may, in extraordinary cases, be performed by the supervisory board. See Code Principle V.E.4.

${ }^{136} \mathrm{I}$ use an adjustment factor of 50 percent because the code merely provides that the supervisory board may appoint the respective committee.

${ }^{137}$ Formation of the audit committee is required by the Securities Market Law (Law 44/2002, 22 November 2002), but composition and remit are explained in the code. The value is 0.5 because the code does not require a majority of the committee's members to be independent directors (however, they must be non-executive directors). The same requirements regarding composition apply to the remuneration committee.

138 According to the code, only the establishment of the nomination committee is mandatory. The functions of the audit and remuneration committees may be performed by the whole board (Code Provisions 7.3 (n. 7), 9.2). But since the board consists almost exclusively of non-executive directors (generally only with the exception of the CEO) and the majority of the directors elected by the shareholders (i.e., excluding the employee representatives on the board) must be independent, the usual conflicts on unitary boards that necessitate the committee structure are muted in the case of Swedish companies. Therefore, it is appropriate to assign the value of 1 , adjusted by 50 percent to take account of the fact that the audit function and remuneration decisions are not separated in an institutionalised way and the CEO (should he/she be a member of the board) and/or other members who are not independent can influence the board's decision-making (note that the code also provides that if the whole board decides about remuneration, no executive director shall participate in this work, Code Provision 9.2).

139 The nomination committee is expected to deal with questions of remuneration. In addition, the board is required to appoint a remuneration committee responsible for drawing up contracts for the key executives.

140 The code does not unambiguously require the members of the audit committee to be independent directors. It merely stipulates that the committee 'should consist of non-executive, preferably independent members of the Board of Directors'. (Emphasis by author.) This means that the provision is in between the definitions of CON(b)(i) and (ii). Applying an adjustment of 50 percent would not be appropriate because then the provision would be effectively coded as $\mathrm{CON}(\mathrm{b})(\mathrm{ii})$. 


\begin{tabular}{|c|c|c|c|c|}
\hline & $\begin{array}{l}\text { (a): } 0.5 ; \\
\text { (b): } 1 ; \text { (c): } \\
1\end{array}$ & $\begin{array}{l}75 \text { for } \\
\text { (b) }{ }^{141}\end{array}$ & $+1) / 3=0.75$ & $\begin{array}{l}\text { Nomination: } 27 \text {; audit: } 23 \text {; } \\
\text { remuneration: } 25\end{array}$ \\
\hline UK & & & & \\
\hline 2010 & $\begin{array}{l}\text { (a): } 1 ;(b): \\
1 ;(c): 1\end{array}$ & 100 & 1 & $\begin{array}{l}\text { Nomination: B.2.1; audit: C.3.1; } \\
\text { remuneration: D.2.1 }\end{array}$ \\
\hline 2003 & $\begin{array}{l}\text { (a): } 1 ; \text { (b): } \\
1 ;(\mathrm{c}): 1\end{array}$ & 100 & 1 & $\begin{array}{l}\text { Nomination: A.4.1; audit: C.3.1; } \\
\text { remuneration: B.2.1 }\end{array}$ \\
\hline 1998 & $\begin{array}{l}\text { (a): } 0.5 ; \\
\text { (b): } 1 ;(\mathrm{c}):\end{array}$ & 100 & $\begin{array}{l}(0.5+1+1) / 3 \\
=0.83\end{array}$ & $\begin{array}{l}\text { Nomination: } 2.7,3.19 \text {; audit: } 2.21 \text {, } \\
6.3 \text {; remuneration: } 2.12,4.11\end{array}$ \\
\hline 1992 & $\begin{array}{l}1 \\
\text { (a): 0; (b): } \\
0.5 ;(c): \\
0.5\end{array}$ & 100 & $\begin{array}{l}(0.5+0.5) / 3 \\
=0.33\end{array}$ & $\begin{array}{l}\text { Nomination: -; audit: } 4.3 \text {; } \\
\text { remuneration: } 3.3\end{array}$ \\
\hline
\end{tabular}

141 See n 140. 
Table B.7. Board structure regulation with binary coding and without adjustment

\begin{tabular}{|c|c|c|c|c|c|c|c|}
\hline Country & $\begin{array}{l}\text { EXD } \\
142\end{array}$ & $\underset{143}{\text { NO_IND }}$ & $\begin{array}{l}\text { DEF_IND } \\
144\end{array}$ & SEP145 & $\begin{array}{l}\text { COOL } \\
146\end{array}$ & $\mathrm{CON}^{147}$ & $\begin{array}{l}\text { Board } \\
\text { structure } \\
148\end{array}$ \\
\hline $\begin{array}{l}\text { Austria } \\
2009 \\
\\
2002\end{array}$ & $\begin{array}{l}\mathrm{n} / \mathrm{a} \\
\mathrm{n} / \mathrm{a}\end{array}$ & 1 & 0 & $\begin{array}{l}\mathrm{n} / \mathrm{a} \\
\mathrm{n} / \mathrm{a}\end{array}$ & 0 & $\begin{array}{l}\text { (a): } 1 ;(b): \\
1 ;(c): 1 \\
=1 \text { in } \\
\text { total } \\
\text { (a): } 1 ;(b): \\
1 ;(c): 1 \\
=1\end{array}$ & $\begin{array}{l}0.75 \\
0.5\end{array}$ \\
\hline $\begin{array}{l}\text { Belgium } \\
2009\end{array}$ & 1 & 0 & 1 & 1 & 0 & $\begin{array}{l}\text { (a): 1; (b): } \\
\text { 1; (c): } 1 \\
=1\end{array}$ & 0.67 \\
\hline 2004 & 1 & 0 & 1 & 1 & 0 & $\begin{array}{l}\text { (a): } 1 ; \text { (b): } \\
1 ;(\text { c): } 1 \\
=1\end{array}$ & 0.67 \\
\hline 1998E & 0 & 0 & 0 & 0 & 0 & $\begin{array}{l}\text { (a): } 0 ;(b): \\
0 ;(\text { c): } 1 \\
=0.33\end{array}$ & 0.055 \\
\hline 1998C & 1 & 0 & 0 & 0 & 0 & $\begin{array}{l}\text { (a): } 1 ;(b): \\
1 ;(c): 1 \\
=1\end{array}$ & 0.33 \\
\hline $\begin{array}{l}\text { Bulgaria } \\
2007\end{array}$ & 0 & 0 & 0 & 1 & 0 & $\begin{array}{l}\text { (a): } 0 \text {; (b): } \\
1 ;(\mathrm{c}): 0 \\
=0.33\end{array}$ & 0.22 \\
\hline $\begin{array}{l}\text { Cyprus } \\
2002\end{array}$ & 0 & 1 & 0 & 1 & 0 & $\begin{array}{l}\text { (a): 1; (b): } \\
1 ;(\mathrm{c}): 1 \\
=1\end{array}$ & 0.5 \\
\hline $\begin{array}{l}\text { Denmark } \\
2010 \\
2003\end{array}$ & 1 & 1 & 1 & 1 & 0 & $\begin{array}{l}\text { (a): } 1 ;(\mathrm{b}): \\
1 ;(\mathrm{c}): 1 \\
=1 \\
0\end{array}$ & 0.83 \\
\hline
\end{tabular}

1421 if the code requires a minimum proportion of non-executive directors that should be at least one-half and 0 otherwise.

1431 if the code requires that a majority of the non-executive directors or members of the supervisory board should be independent and 0 otherwise.

1441 if at least half of the independence requirements listed above in Table A.1 have to be satisfied in order to qualify as an independent director (i.e. the value of DEF_IND should be at least 0.5 before adjustment) and 0 otherwise.

145 Coding as above Table A.1, but without adjustments.

1461 if the code provides that the CEO/chairman of the management board shall not go on to be chairman of the board/supervisory board for a period of at least one year after the end of his/her tenure as CEO.

${ }_{147}$ Coding as above Table A.1, except that cases (i) and (ii) for each committee are conflated and receive the value 1.

148 The total board structure variable equals the mean of the six or four individual elements, as applicable to systems with one-tier and two-tier boards, respectively. 


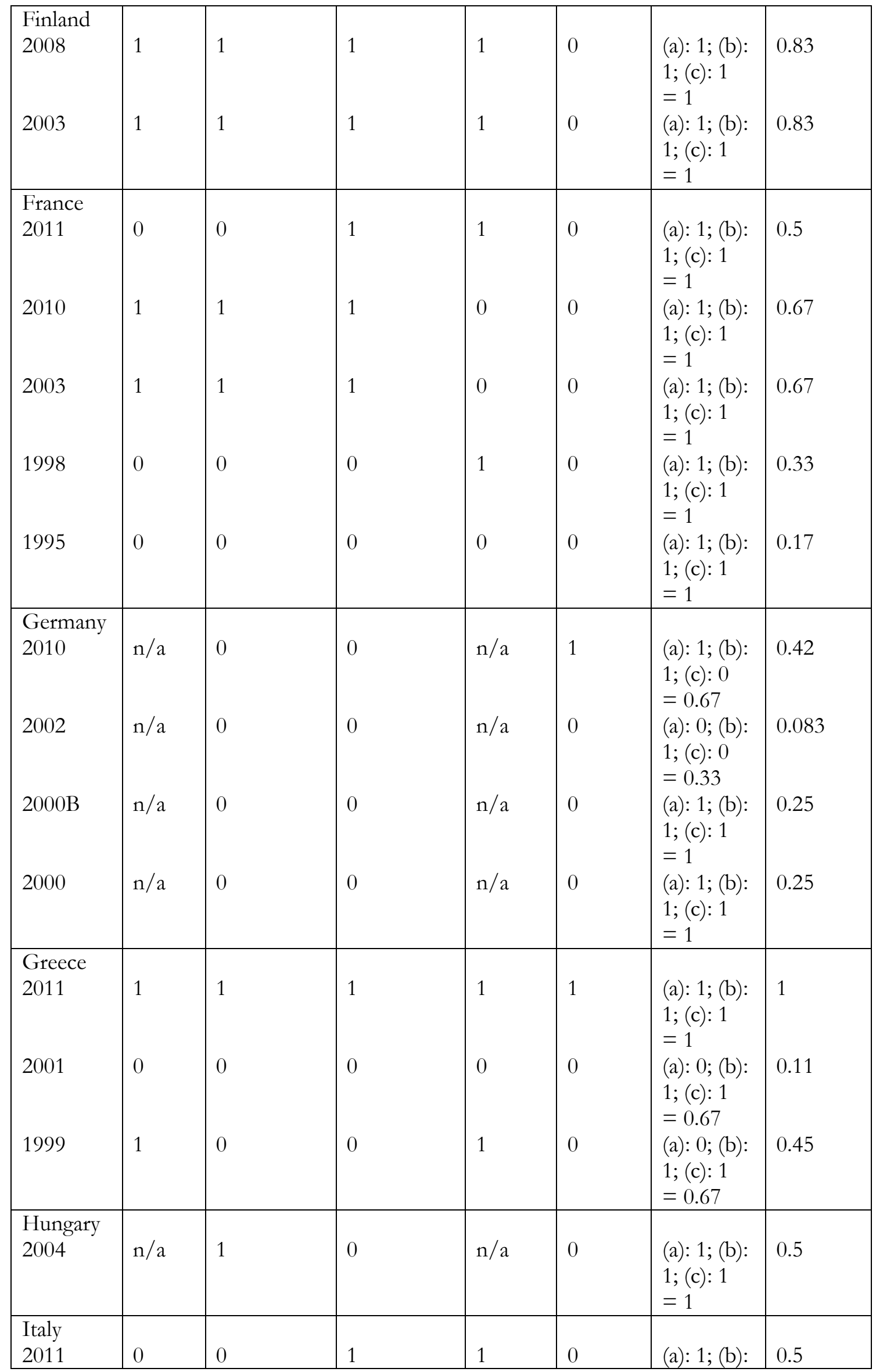




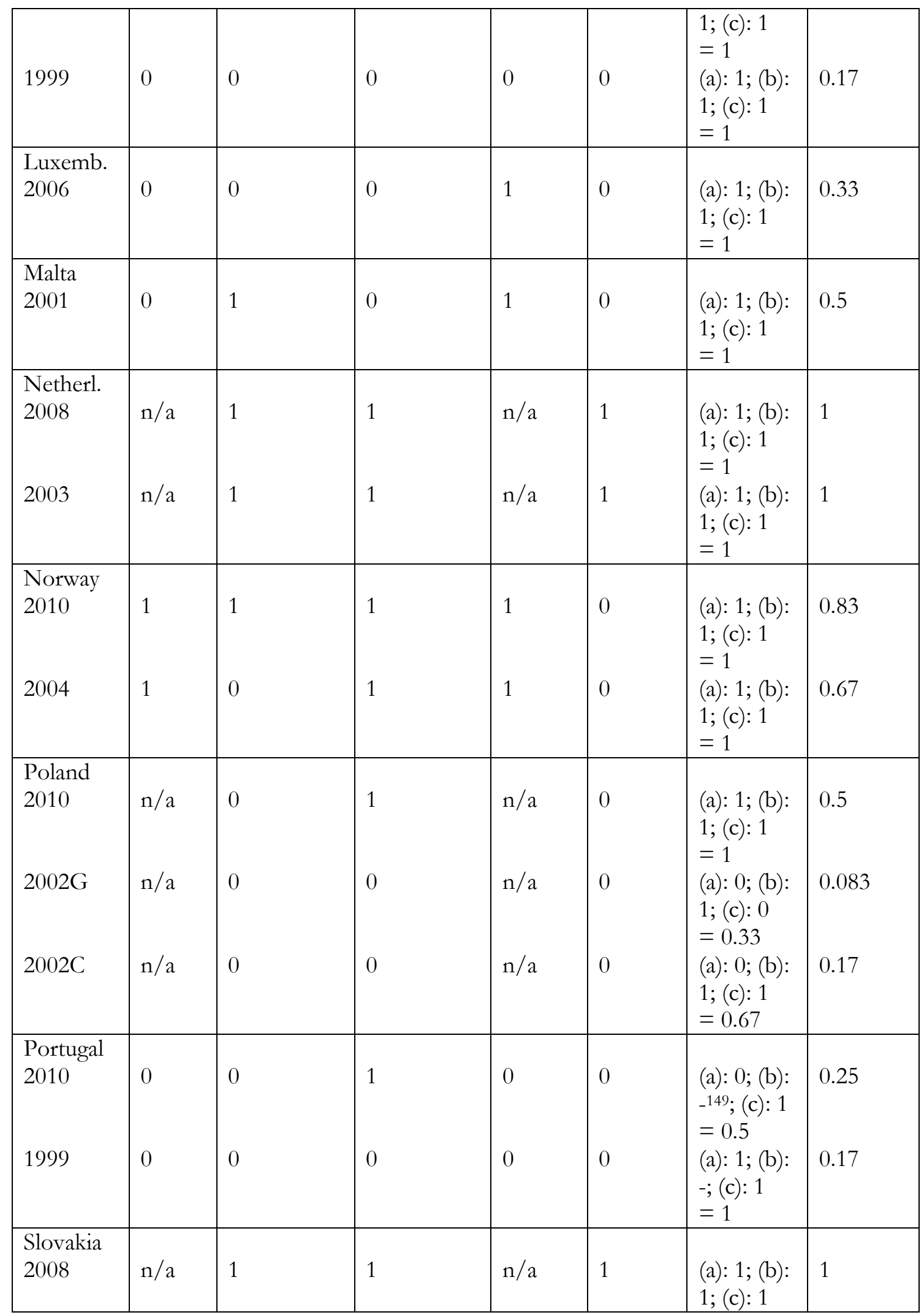

149 See n 133 above. 


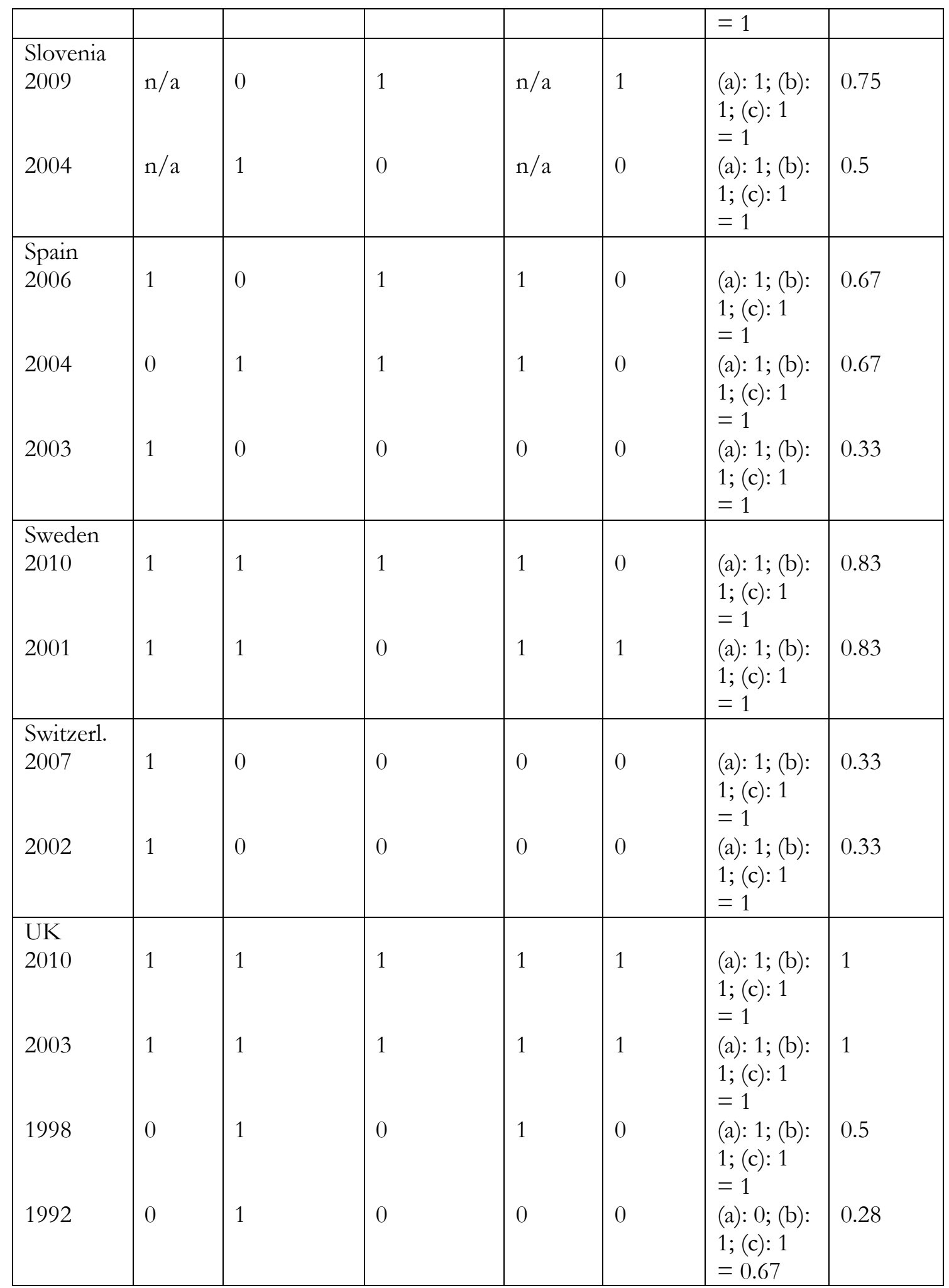

